\title{
The 2020 Re-Excavation of Callao Cave, Northeastern Luzon, the Philippines Ang Muling Pagsusuring Archaeological sa Callao Cave, Hilagang-Silangang Luzon, Pilipinas sa 2020
}

\author{
Kathleen D. Tantuico, J.D. \\ University of the Philippines \\ College of Law and Archaeological Studies \\ Program \\ kdtantuico@up.edu.ph
}

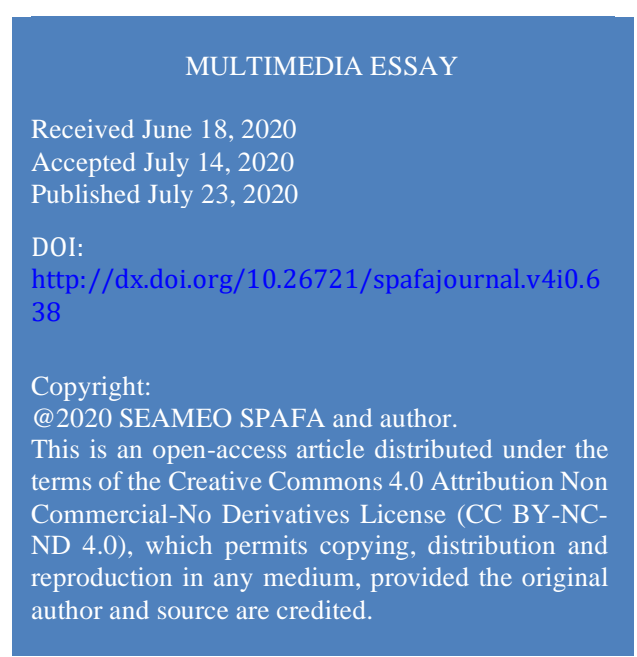

\begin{abstract}
This article provides a first-person perspective on the experiences of the archaeologists who reexcavated Callao Cave in Cagayan Province, Northeastern Luzon, Philippines. It describes the environment, everyday routine and methodology of the 45-day excavation. It does not provide an enumeration of artefacts and other archaeological findings, but rather describes how artefacts were obtained and how data was recorded during the excavation. Callao Cave is the archaeological site where the remains of the recently identified Hominin species Homo luzonensis were obtained during previous excavations in 2015, 2011, 2009 and 2003.
\end{abstract}

Ibinabahagi ng kasulatang ito ang mga karanasan ng mga archaeologist na muling sumuri gamit ang archaeological excavation sa Yungib ng Callao, sa Lalawigan ng Cagayan, Hilagang-Silangang Luzon, Pilipinas. Gamit ang pananaw ng manunulat, inilalarawan ang kapaligiran, pang araw-araw na kaganapan at ang pamamaraang archaeological sa pagsusuri ng Yungib ng Callao sa loob ng 45 na araw. Sa Yungib ng Callao natagpuan ang mga buto ng Homo luzonensis, ang bagong natuklasang Hominin species noong mga unang archaeological excavation noong 2015, 2011, 2009 at 2003.

Keywords: field archaeology, excavation, research, Callao Cave, Philippines | Arkeoloji, pagsusuri, pananaliksik, Yungib ng Callao, Pilipinas, Cagayan

In February to March, 2020, a team of archaeologists from the University of the Philippines' Archaeological Studies Program, the National Museum of the Philippines and the Musée de l'Homme in Paris, France, conducted a six-week re-excavation of the Callao Cave System in Barangay Agguggadan, Peñablanca, Cagayan Province in northeastern Luzon Island, The 
Philippines. Callao Cave was previously excavated by the National Museum of the Philippines in the 1970s, followed by excavations led by Dr. Armand Salvador Mijares of the University of the Philippines' Archaeological Studies Program in 2003, 2009, 2011 and 2015.

One of the most significant archaeological finds obtained from previous excavations at Callao Cave were fossilized human bones and teeth, which included a 67,000-year-old foot bone of the newly discovered species of hominin, Homo luzonensis. These findings add to existing paleoanthropological record of Island Southeast Asia, particularly the Homo floresiensis from Flores, Indonesia, which was first reported in 2004. These findings also contributed information to the hominin record of East and Southeast Asia, signaling the re-evaluation of existing knowledge on human evolution and the interaction of human species in prehistoric Southeast Asia, as published in the 2019 paper entitled "Homo from the Late Pleistocene of the Philippines," in the highly acclaimed international scientific journal Nature (Détroit et al. 2019: 181-186).

This year's excavation aimed to retrieve more ancient human fossils and artefacts that could provide additional information on the newly discovered Hominin species Homo luzonensis.

This photo essay provides a first-person perspective of experiences from the 2020 re-excavation of Callao Cave. It hopes to present a description of an archaeologist's everyday activities, and paint a picture of the excavation process, the environment, and other duties of archaeologists while in the field. It will not include the scientific results of the excavation, but rather the experiences that surrounded the retrieval of artefacts and other archaeological information from the site, as well as the community engagement involved in all archaeological excavations.

\section{Peñablanca: A Protected Landscape}

Callao Cave is in Barangay Agguggadan, a small community in the Municipality of Peñablanca in Cagayan Province. The word "Peñablanca" is a conjoinment of two Spanish words that literally translates to "white rock" to allude to the numerous limestone formations that line the ridges by the Pinacanauan River.

Since 2018, under present Philippine law (Republic Act No. 11038), Peñablanca is considered as a both a Protected Area and a National Park. Protected Areas possess unique physical and biological diversity and is protected against human destruction and exploitation $\left(17^{\text {th }}\right.$ Congress of the Philippines. 2017: Section 3(b.b)As a National Park, it is an area "primarily designated for the conservation of native plants and animals, their associated habitats and cultural diversity" $\left(17^{\text {th }}\right.$ Congress of the Philippines. 2017: Section 3(v).

Previously, the old law (Republic Act No. 7586) which the present law amended, considered Protected Landscapes and Seascapes as "areas for public enjoyment through recreation and tourism" ( $8^{\text {th }}$ Congress of the Philippines. 1992. Section 4(9)). Today, the present law not only considers Callao Cave's economic value as a tourist destination, but also recognizes its value to Philippine biodiversity and ecology. Thus, there are corresponding penalties for its intentional destruction and the unauthorized appropriation of its natural resources.

Several past Philippine Presidents have also formally recognized the significance of Callao Cave through Presidential Proclamations since the 1930s. Under Proclamation No. 827, Callao Cave and 
its surrounding areas were recognized as one of the country's first National Parks in as early as 1935 (Quezon 1935). In 1994, more ecologically important areas and cave systems in Peñablanca, including Callao Cave, were recognized and reclassified into the "Peñablanca Protected Landscape" through Proclamation No. 416. As such, these areas were placed under the management of the Department of Environment and Natural Resources, which was tasked to conserve, manage and protect their scenic, cultural, historical, scientific, recreational and archaeological features (Ramos. 1994). By 2003, another Presidential Proclamation (Proclamation No. 484) expanded the area's coverage and it was again reclassified and renamed as the "Peñablanca Protected Landscape and Seascape" (Macapagal-Arroyo 2003).

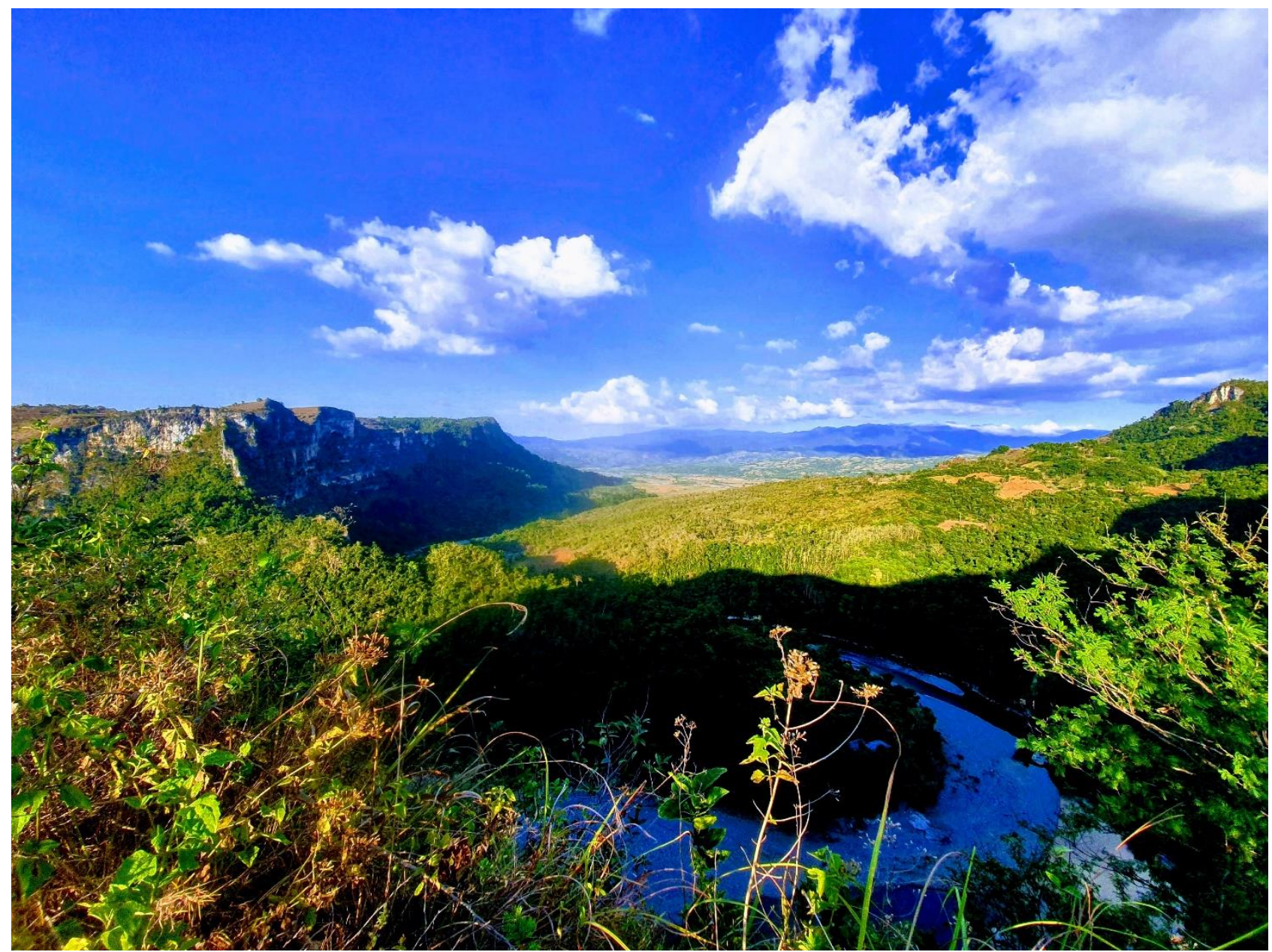

Fig. 1 Callao cave is located within a Protected Area and Natural Park. Its biologically diverse landscape is alluring. Some members of the team would take "nature walks" every afternoon after a hard day's work, in what we considered as the "back yard". This is a view of the riverbend from the top of the ridge fifteen minutes away from the archaeologists' quarters. Source: KD Tantuico, 21 March 2020.

\section{Callao Cave: An Important Cultural Property}

Previous archaeological studies have shown that Callao Cave yields both Paleolithic and Neolithic archaeological assemblages. It yielded artefacts such as andesite and chert flake tools, black earthenware sherds, a spindle whorl, and faunal remains such as deer teeth, wild boar tusks, pig teeth and bat bones (Mijares. 2006).

Callao Cave is just one system in the area with its numerous sinkholes and massive stalagmites, it is arguably the most complex and unique. These are the characteristics that most probably attracted 
international scholars to examine its features and resources. Under Philippine Law, the Callao Cave is considered both as a natural and cultural property, and is protected from destruction by two special laws: The National Caves and Cave Resources Management and Protection Act (Republic Act Number 9072), or the "Cave Law"; and the Cultural Heritage Act of 2009 (Republic Act Number 10066) or the "Heritage Law". Under both laws, Callao Cave is protected from intentional and unintentional destruction, alteration, and the unauthorized removal of its resources, including archaeological artefacts $\left(11^{\text {th }}\right.$ Congress of the Philippines 2001: Section $8 ; 14^{\text {th }}$ Congress of the Philippines 2010: Sections 48 and 49).

In 2015, Callao Cave was declared as an Important Cultural Property under the Heritage Law. As such, it is considered as having exceptional cultural significance to the Philippines, as determined by the National Museum ( $14^{\text {th }}$ Congress of the Philippines . 2010: Article II Section 3(w). A few days prior to the start of the excavation, international archaeologists and scientists, as well as a few members of the excavation team attended the unveiling of the official heritage marker at the cave's entrance. This was facilitated by the National Museum of the Philippines and the provincial officers of Cagayan Province.

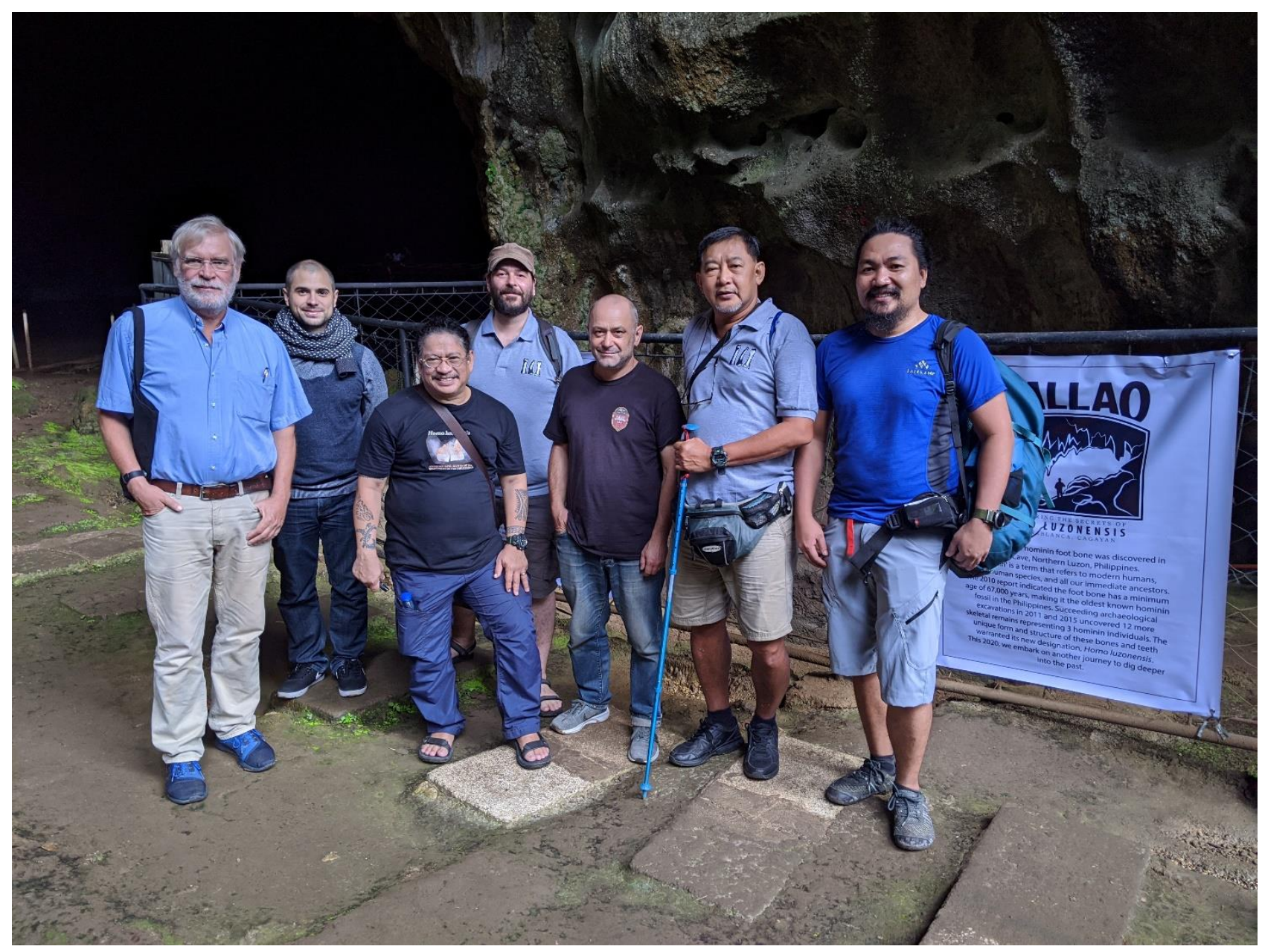

Fig. 2 International and Filipino archaeologists who were co-authors of the scientific article "Homo from the Late Pleistocene of the Philippines" published in the international scientific journal "Nature" returned to the Callao Cave Complex to attend the unveiling of the cultural marker at the Callao Cave's entrance. Back: Dr. Clement 
Zanolli; Dr. Florent Détroit; Front: Dr. Rainer Grün; Dr. Armand Mijares; Dr. Philip Piper; Dr. Eusebio Dizon; Mr. Emil Robles. Source: Kristine Kate Lim, 7 February 2020.

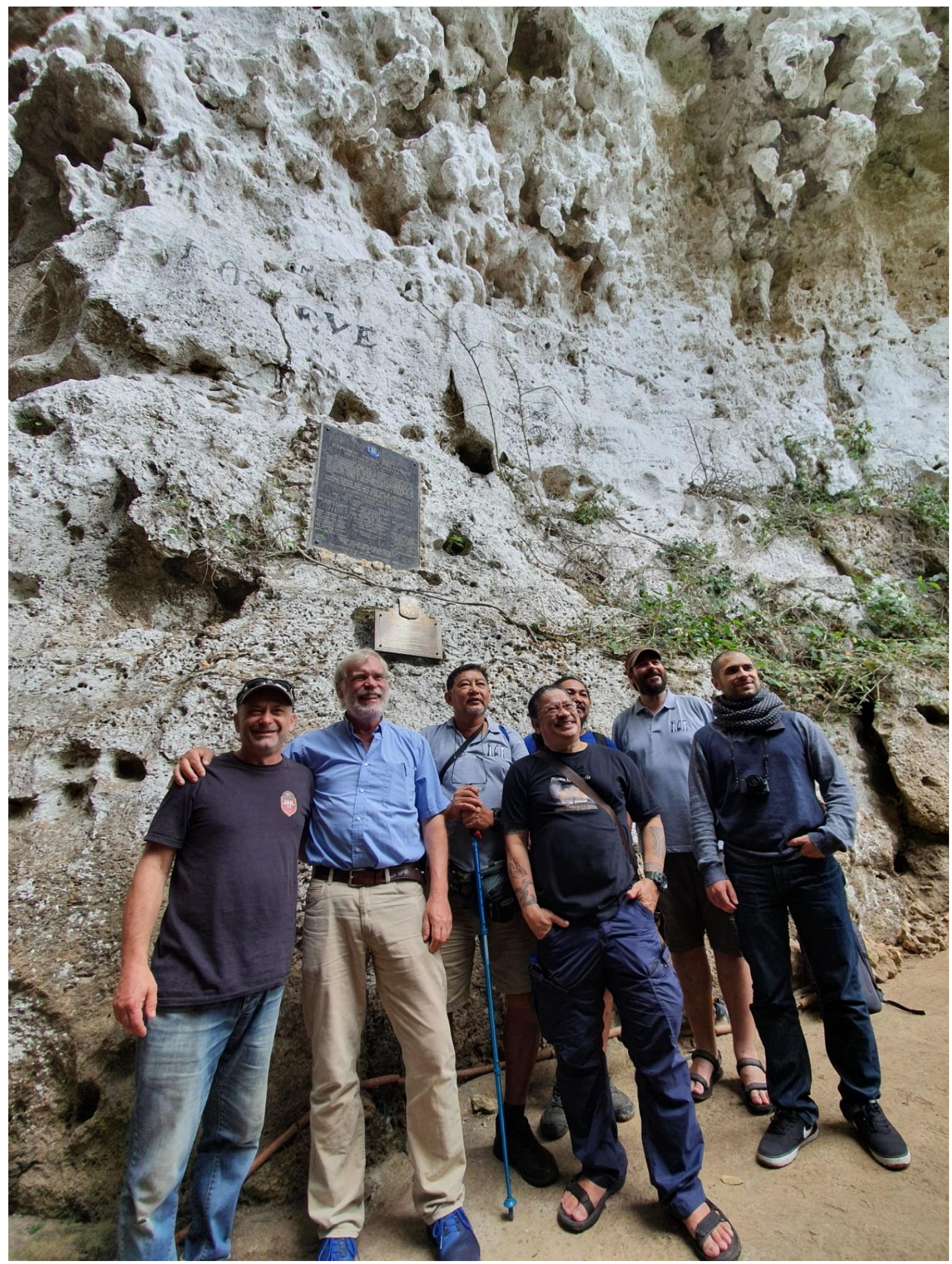

Fig. 3 A photo of the international and Filipino archaeologists with Callao Cave's cultural marker. Source: KD Tantuico, 7 February 2020. 


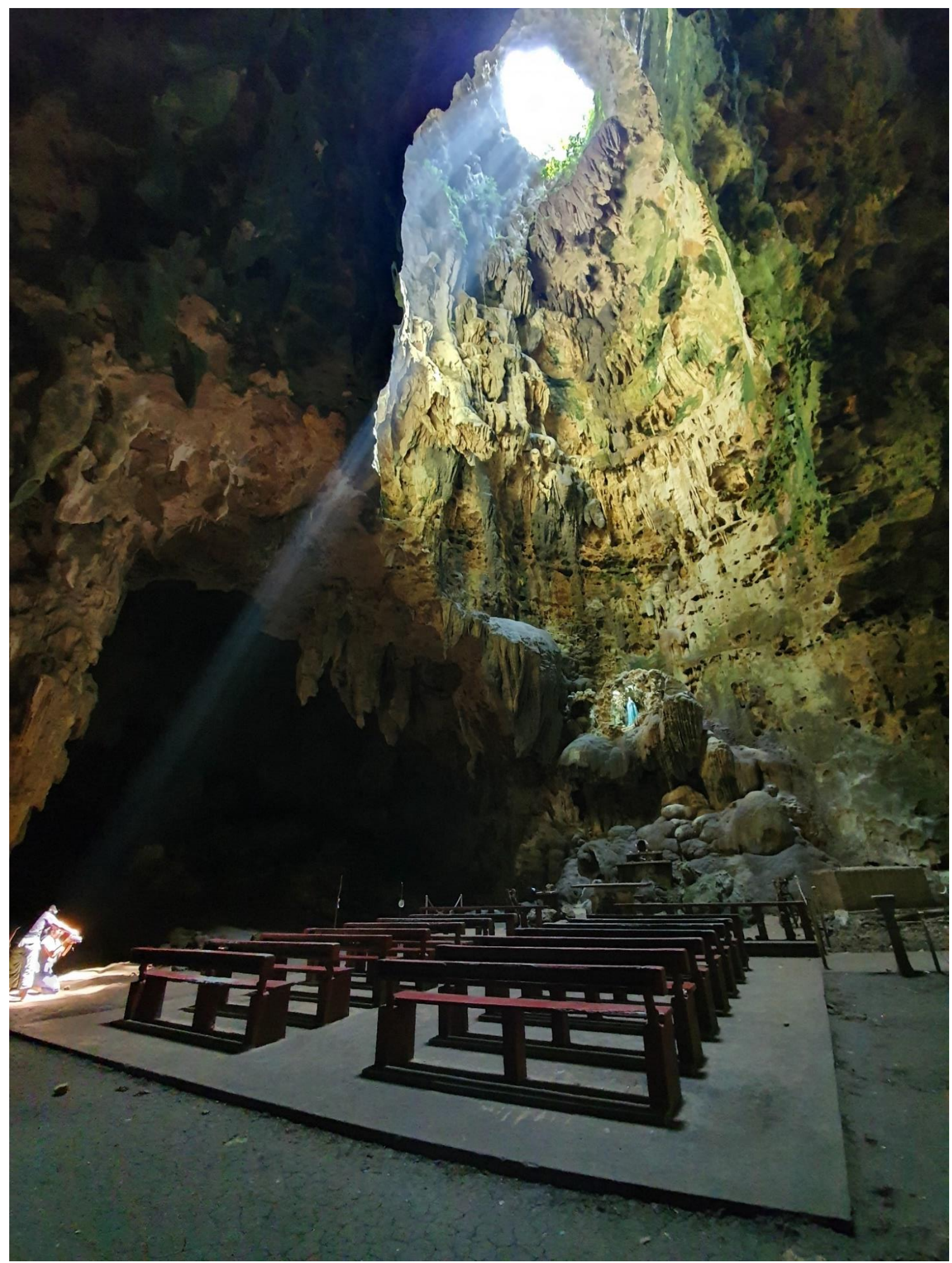

Fig. 4 A chapel was built in Callao Cave's second chamber in 1972. A large sink hole allows light to reflect into the chapel. Source: KD Tantuico, 19 March 2020. 


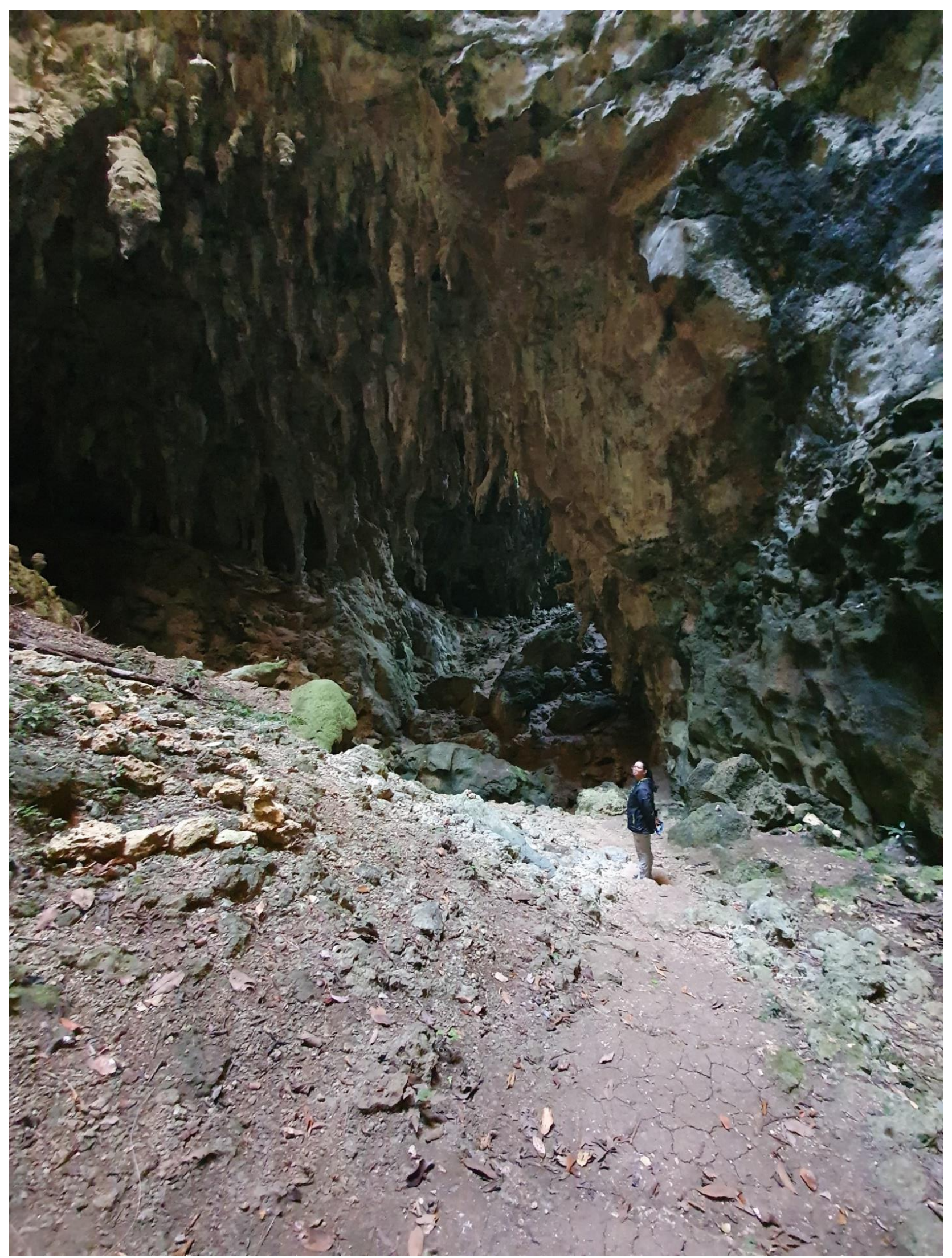

Fig. 5 A member of the excavation team explores one of Callao Cave's seven chambers. Source: KD Tantuico, 6 March 2020. 


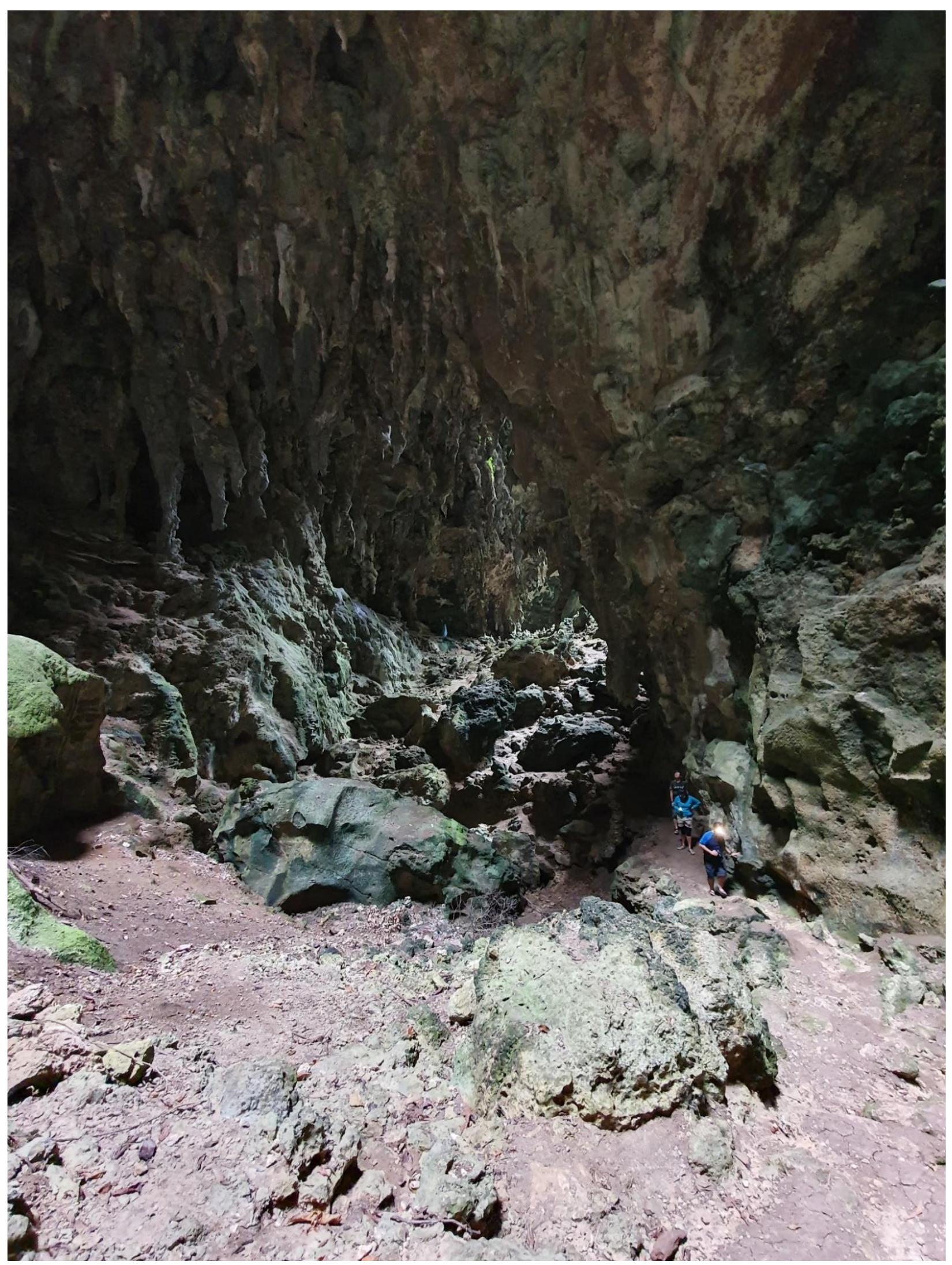

Fig. 6 Members of the excavation team were in awe at Callao Cave's massiveness and countless stalagmites. Source: KD Tantuico, 6 March 2020. 


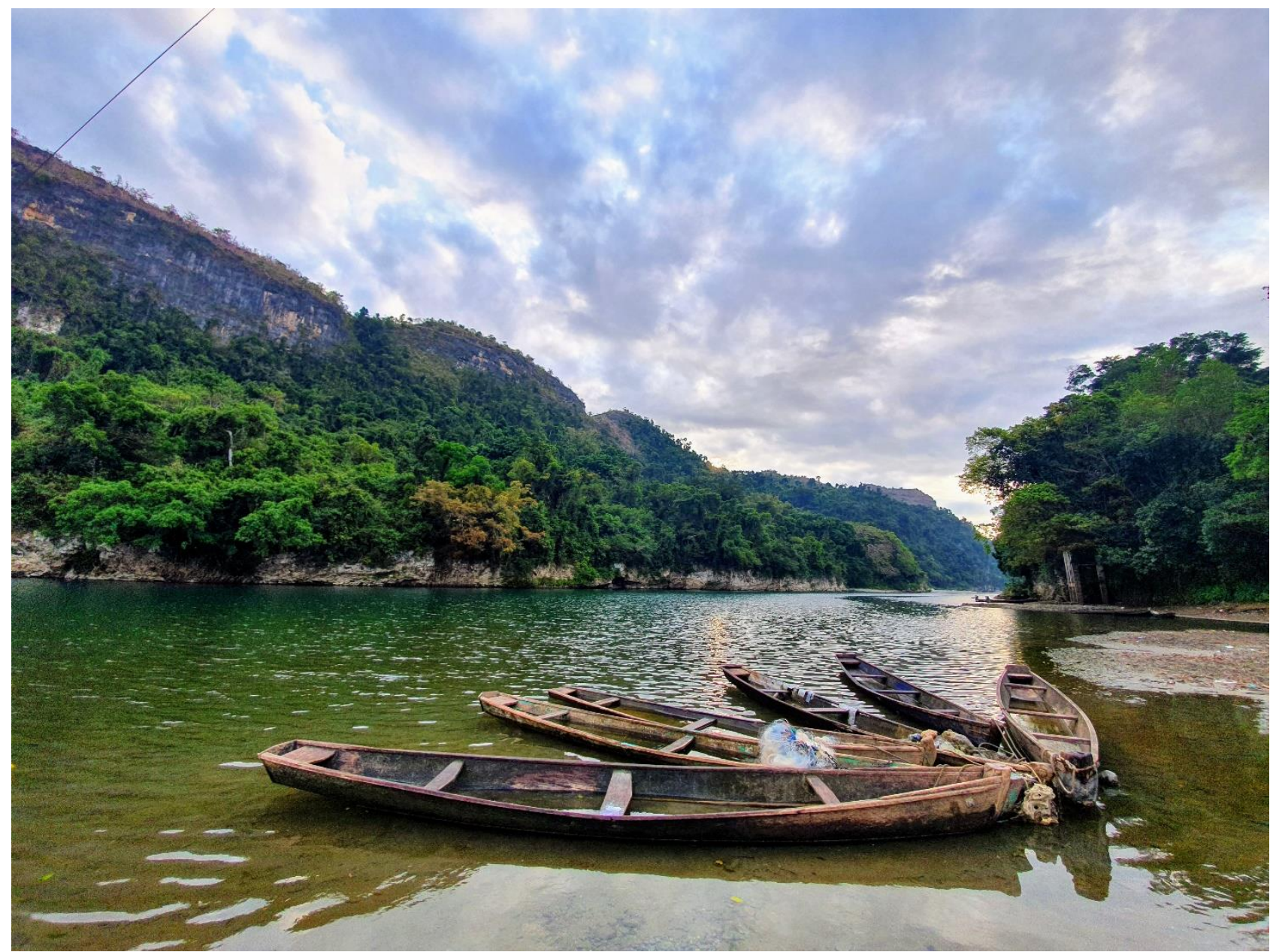

Fig. 7 The Pinacanauan River is the longest river in the Province. It served as the team's permanent water source, and on many occasions, supplied them with fresh fish caught by fishermen who are ready for the day's catch as early as 4:00 a.m. Source: KD Tantuico, 14 March 2020.

\section{The Archaeologists' Daily Routine}

Callao Cave is located on a mountain ridge along the Pinacanauan River in Barangay Agguggadan, in the Municipality of Peñablanca, Cagayan Province. For six weeks, the archaeological team stayed in a house on the opposite bank of the river. Each day, they rode on a small canoe that could fit four to five people each trip to arrive at the opposite bank. From the dock site, they climbed steep stairs to lead them to the main reception area accessible to tourists. They then climbed another set of 184 steps to finally access the cave entrance, where the excavation site was located. 


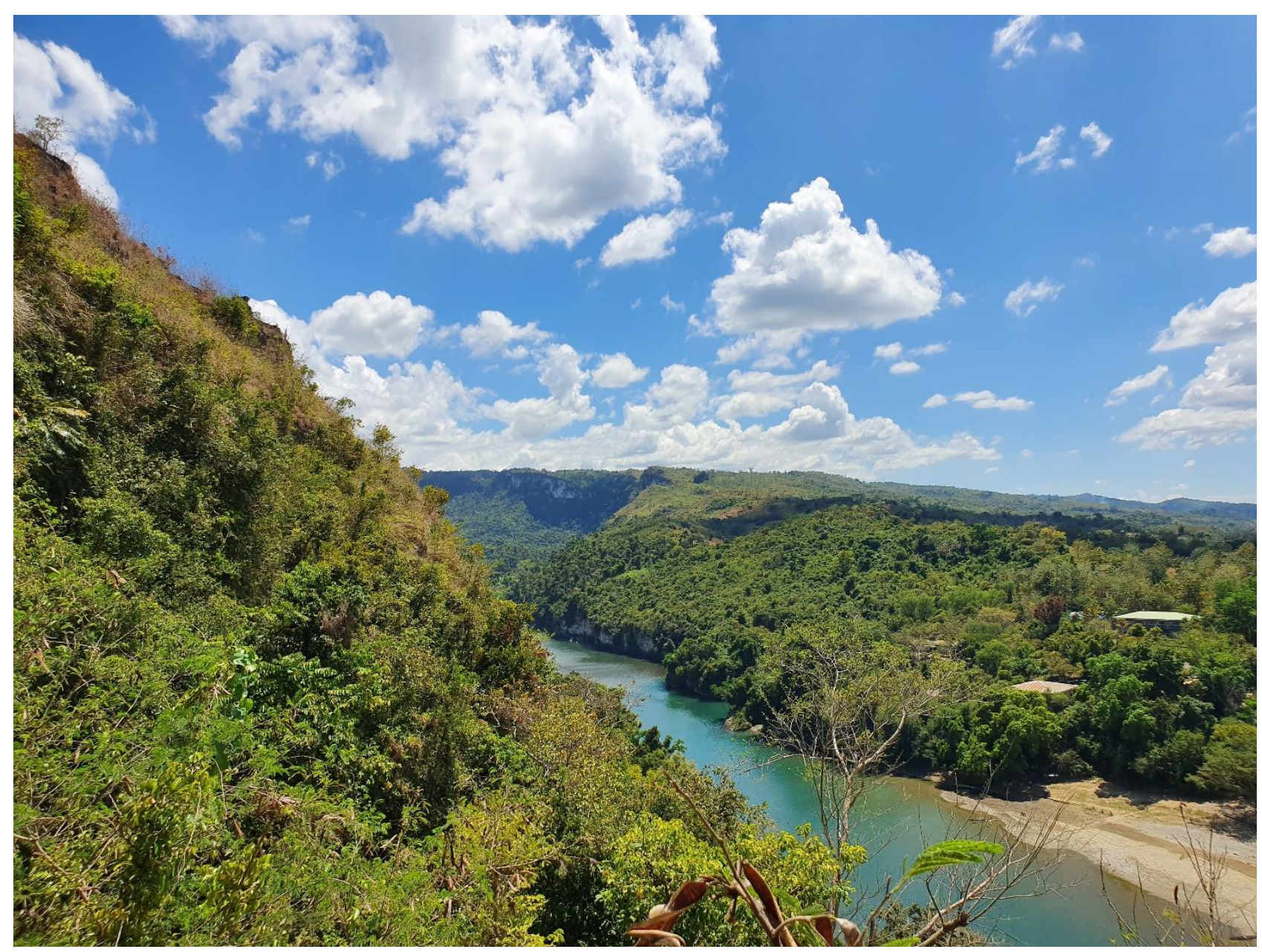

Fig. 8 The excavation team was housed in one of the houses on the right side of the Pinacanauan River. Every morning, they walked to the riverbank and took turns being ferried by a small boat to a docksite at the opposite bank. From there, they would climb 184 steps on the ridge to access the archaeological site. This photo was taken from a viewdeck by Callao Cave's entrance. Source: KD Tantuico, 12 March 2020. 


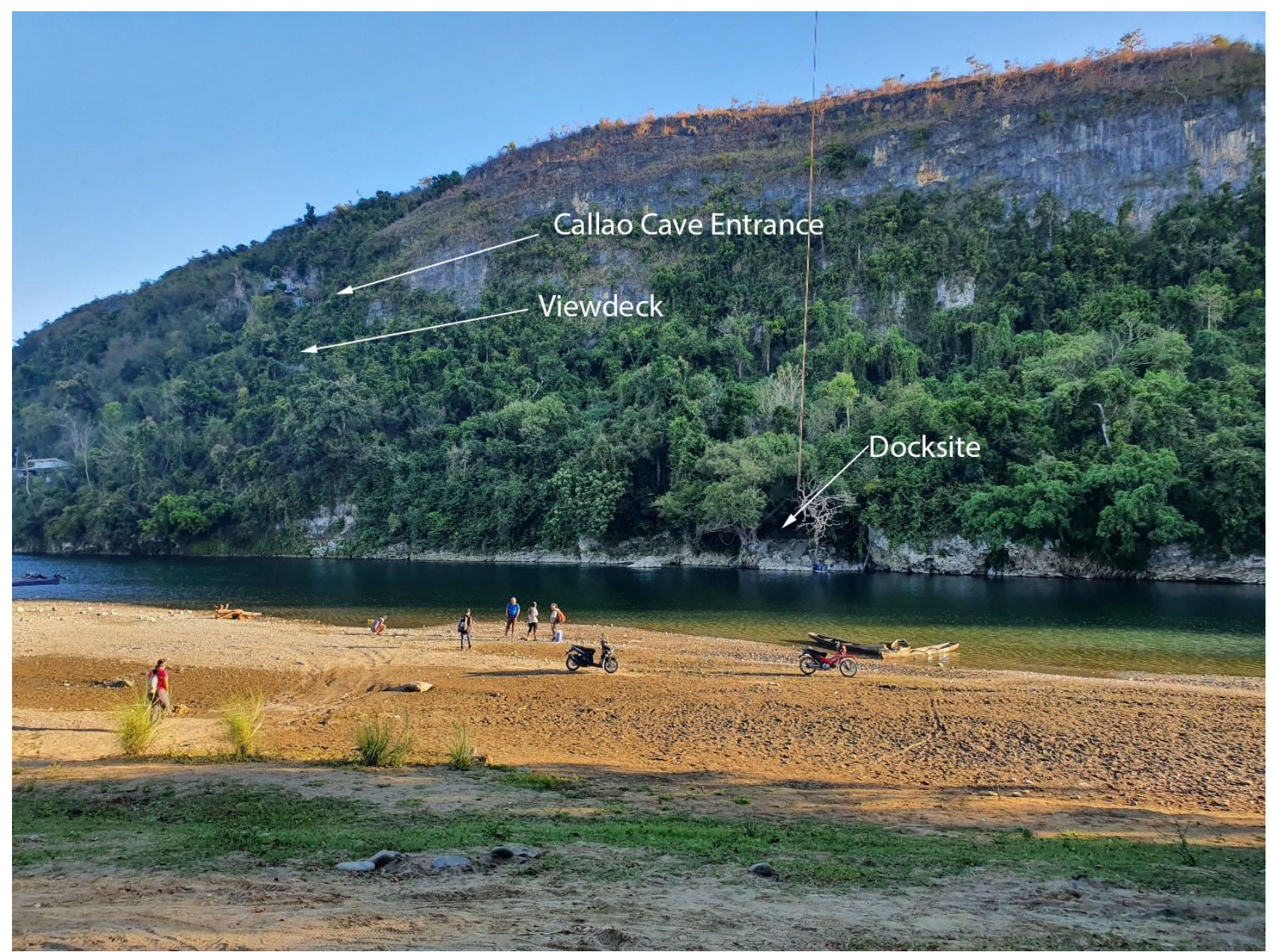

Fig. 9 Every morning, the team would walk from their quarters to the riverbank to and wait for their turn on the canoe before 7:00 a.m. The morning sun was generous in shining its rays, which, the team believed, was a healthy daily dose of Vitamin D. Source: KD Tantuico, 12 March 2020. 


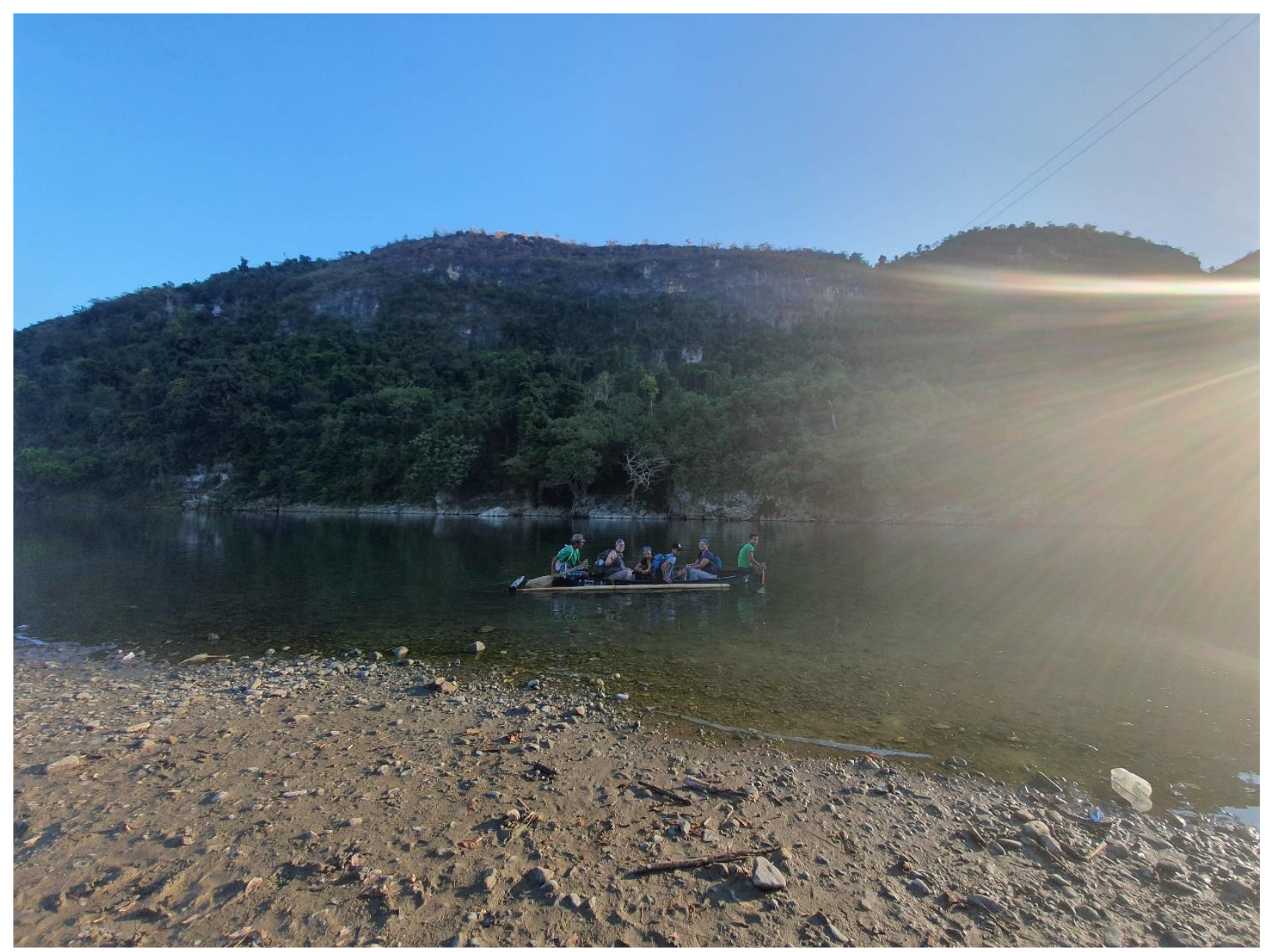

Fig. 10 The team would start crossing the river by 7:00 a.m. at the latest. The canoe-type boat would be steered by a steersman and one paddler. Makeshift bamboo outriggers were installed to ensure stability. Source: KD Tantuico, 12 March 2020. 


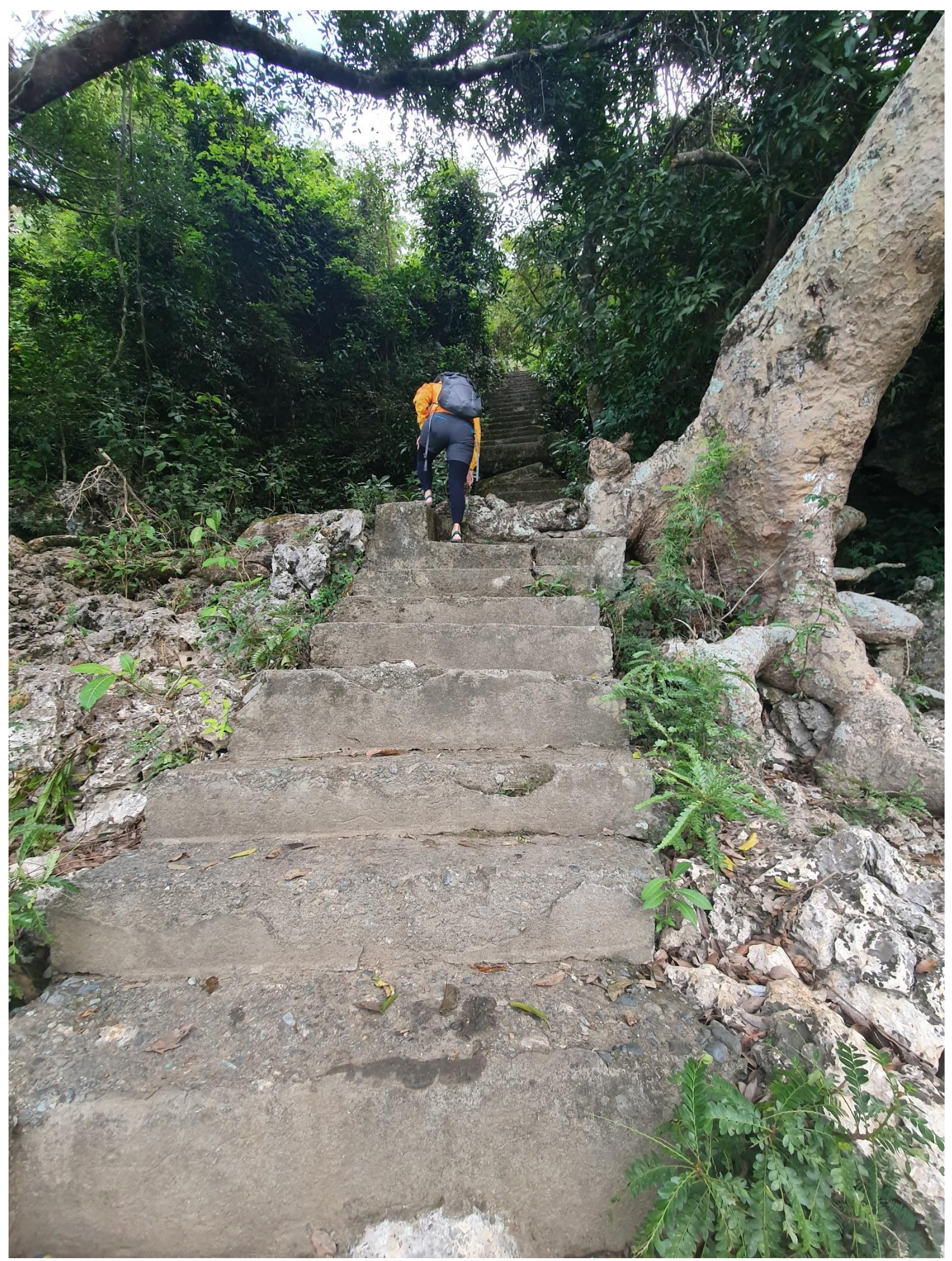

Fig. 11 Upon alighting from the canoe, the archaeologists would climb steep stone steps that led to the main area accessible by tourists. Source: KD Tantuico, 27 February 2020. 


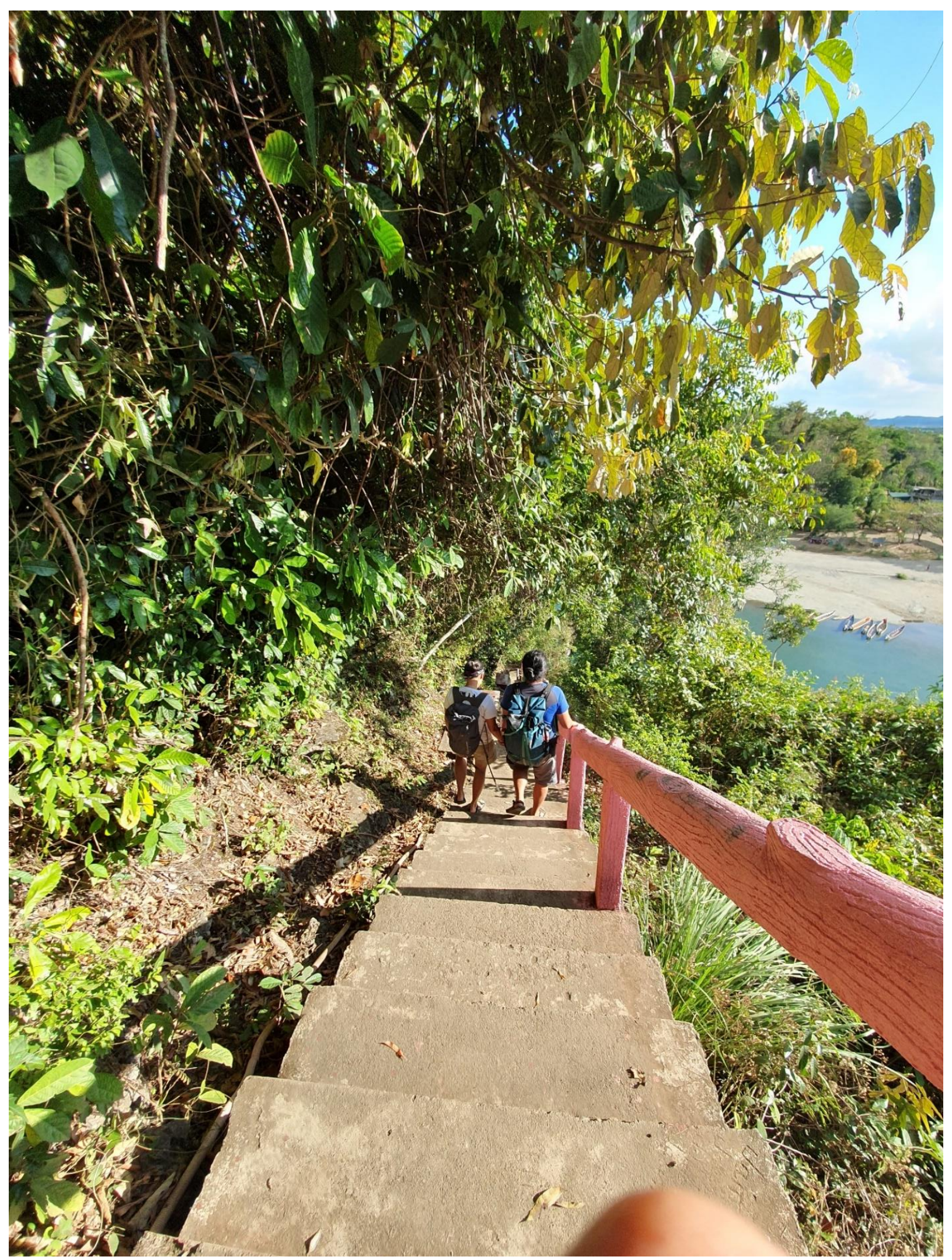

Fig. 12 After a day's work, the team would start packing up at 4:00 p.m. daily from Monday to Friday, and until noon on Saturdays. The walk down the ridge was definitely quicker and less physically demanding than the trek up. The view made us forget our exhaustion in most instances. Source: KD Tantuico, 11 March 2020. 
Upon reaching the excavation site, the archaeologists would set-up their equipment that was stored in a locked crate at the site. In this photo, the archaeologists are setting up the Total Station Theodolite. Used for mapping archaeological sites, this machine enables archaeologists to record certain points (Schneider and Panich. 2008 :167). It situates the excavation area into a grid system.

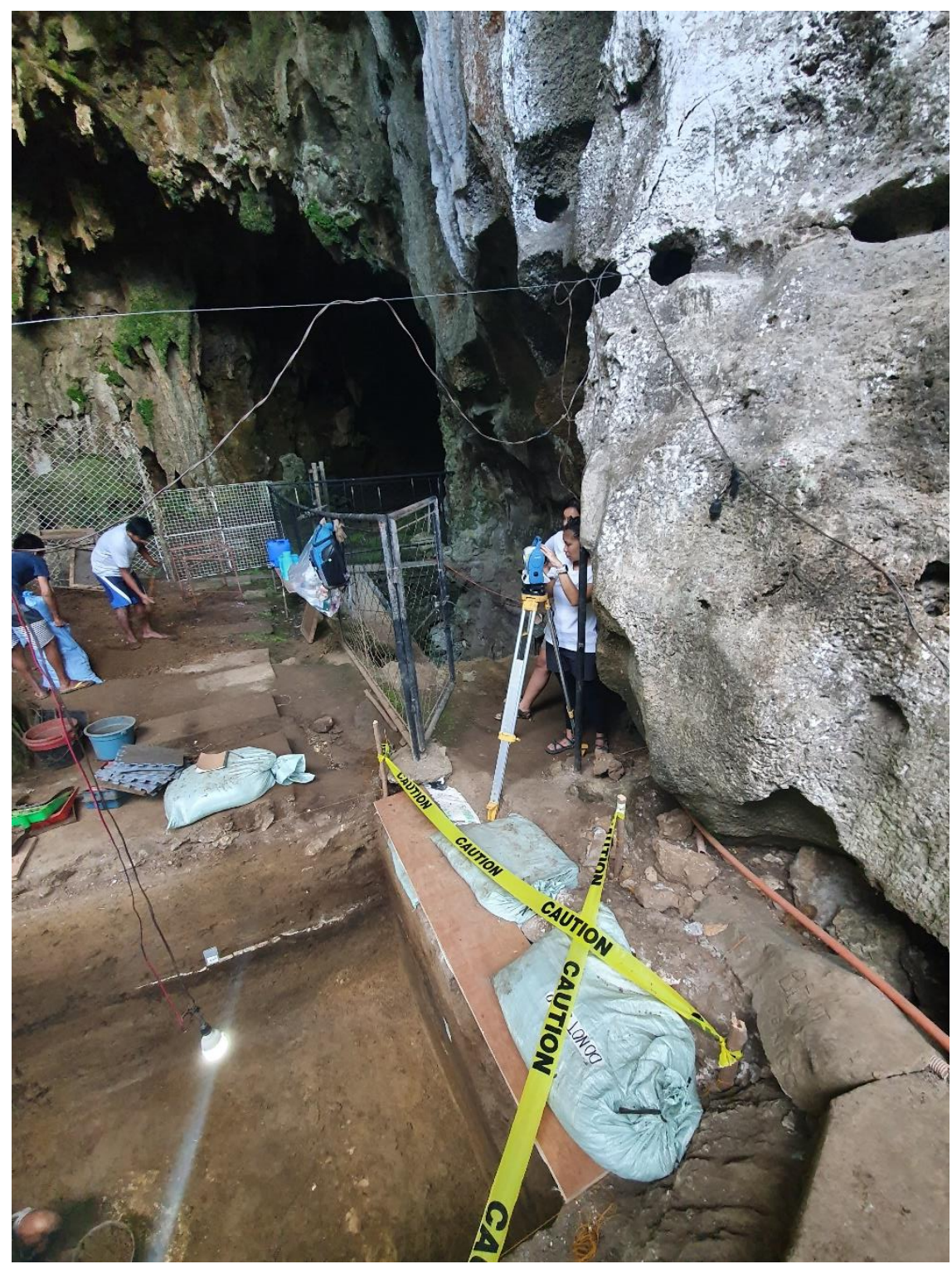

Fig. 13 One of the first things that archaeologists did upon reaching the site every morning was to set up the Total Station Theodolite. Here, archaeologists are targeting certain datum points that have situated the site into a grid system. Source: KD Tantuico, 27 February 2020.

To set-up a Total station Theodolite, one has to aim and target pre-set datum points and letting the machine do its calculations. Once it was ready, the team could now map the area, measure elevations and plot any coordinates, while maintaining a digital database of coordinates within the site. 


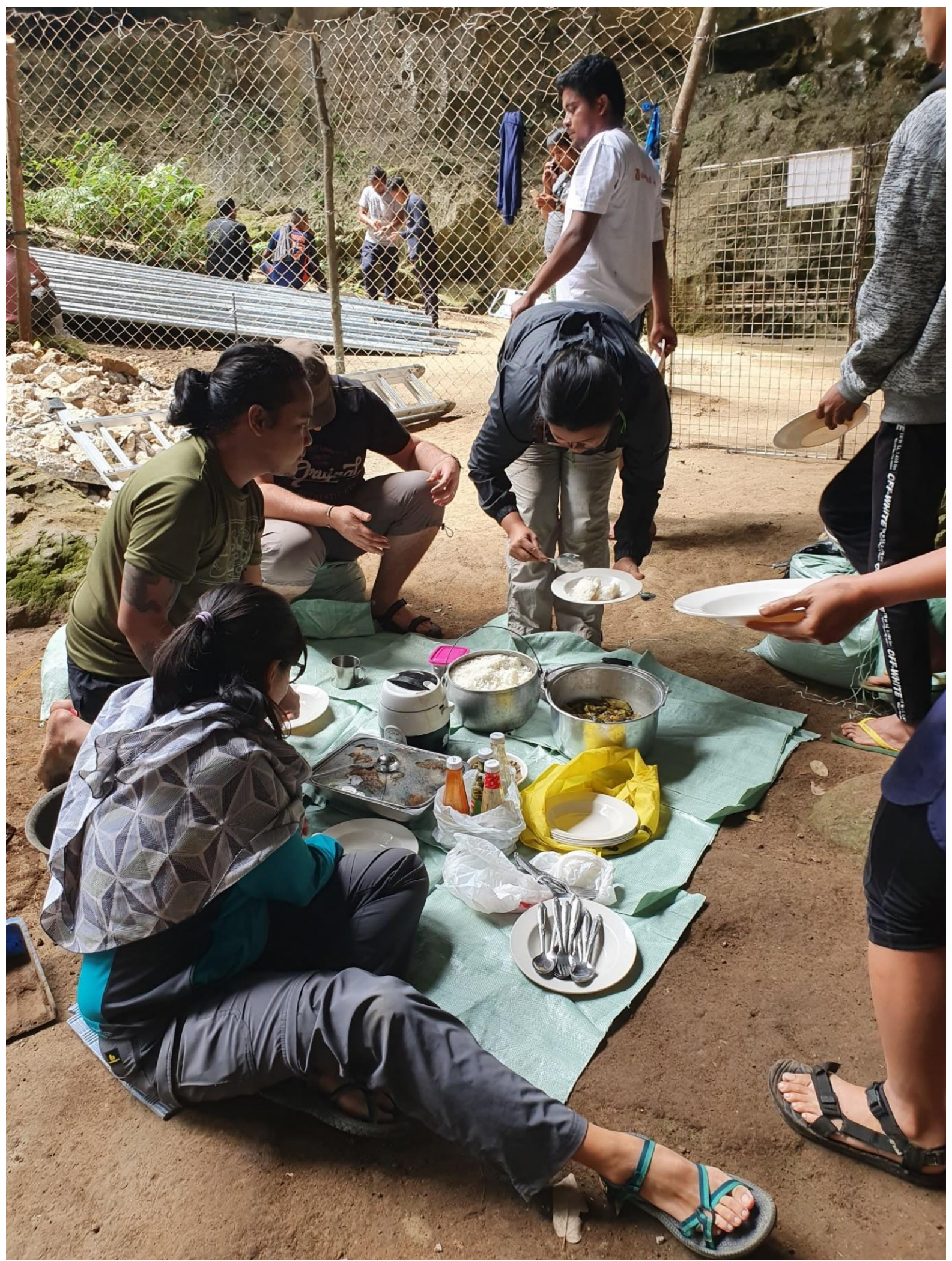

Fig. 14 Freshly cooked lunch by our designated cook, Mr. Domingo Pagulayan would be delivered to the cave by our laborer-technicians by 11:30 a.m. They would climb down from the cave, paddle across the river, pick-up the food from our quarters and go back to the cave. We would eat on benches or on the sacks of sediments stored at the cave entrance. Source: KD Tantuico, 27 February 2020. 


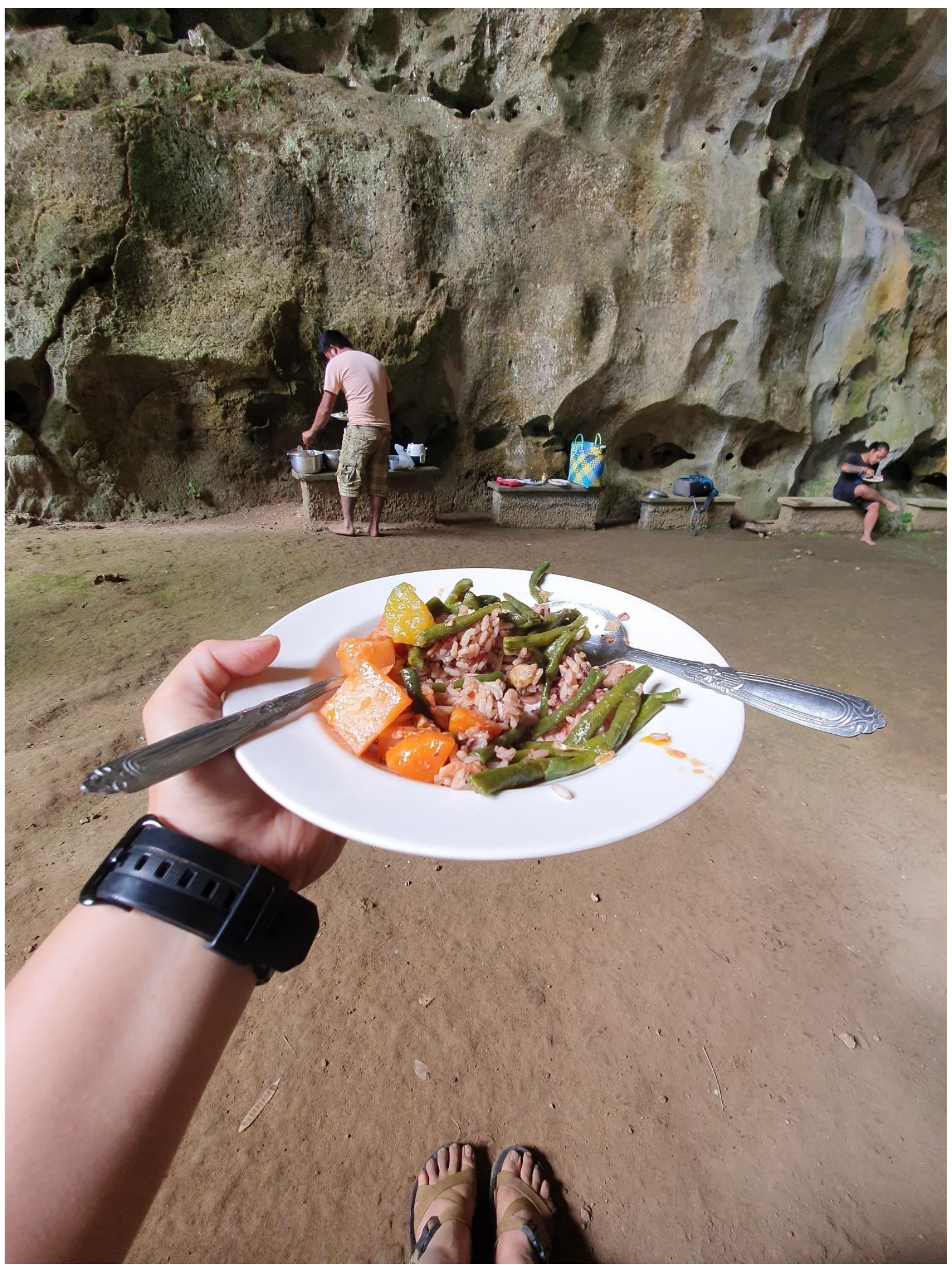

Fig. 15 Not only would the food be delicious, it would also be fresh and nutritious. A mix of meat, seafood, vegetables on either plain or brown rice every day would be sure to energize us for the rest of the day. Source: KD Tantuico, 24 February 2020. 


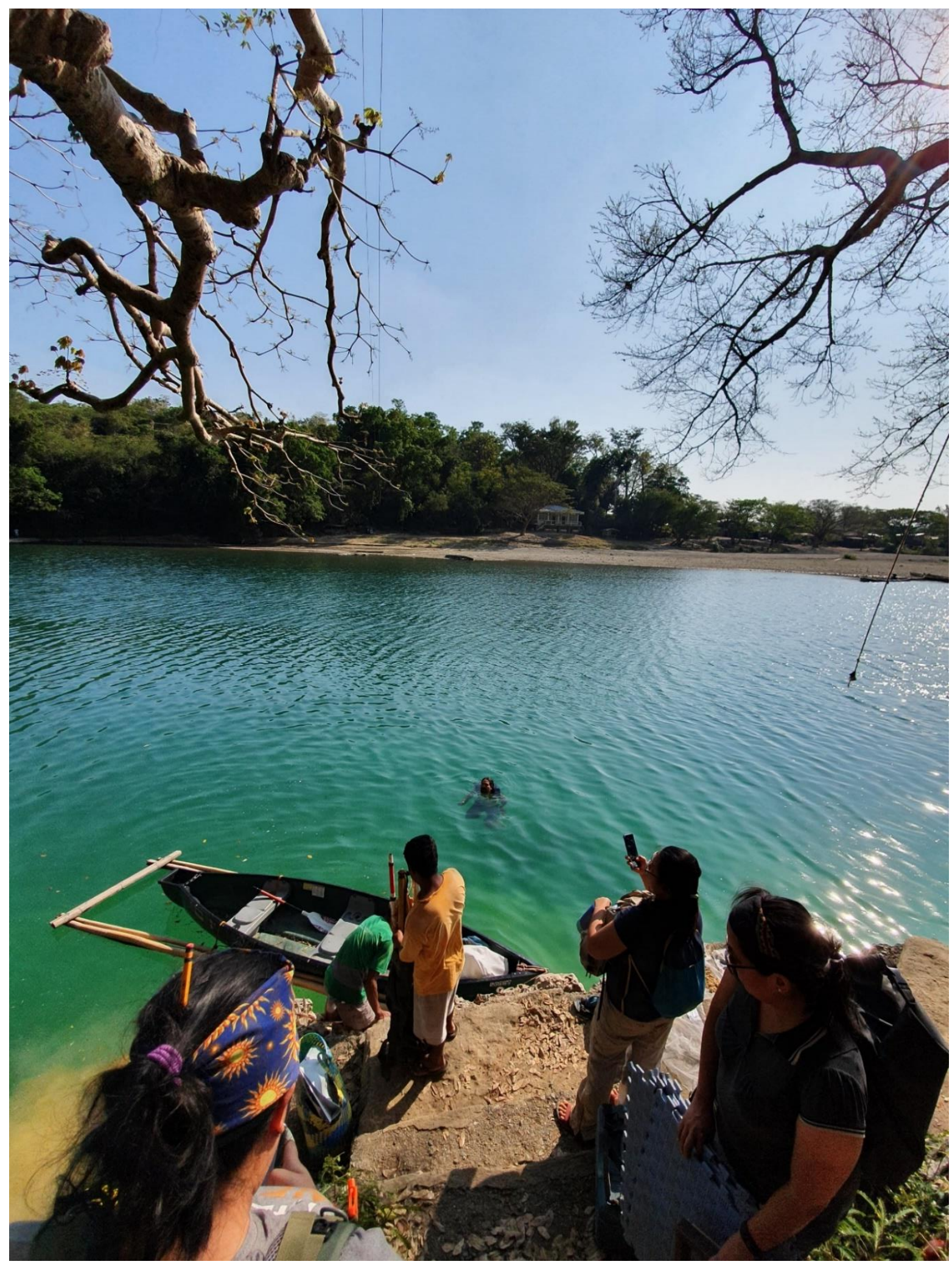

Fig. 16 The river's waters would be a different color in the afternoon. Compared to dark greenish blue in the mornings, the afternoon waters would reflect a tinge of turquoise thanks to the afternoon sun. This would entice some of us to swim. I would swim back across most of the time, but only if the current was bearable. Source: KD Tantuico, 3 March 2020. 


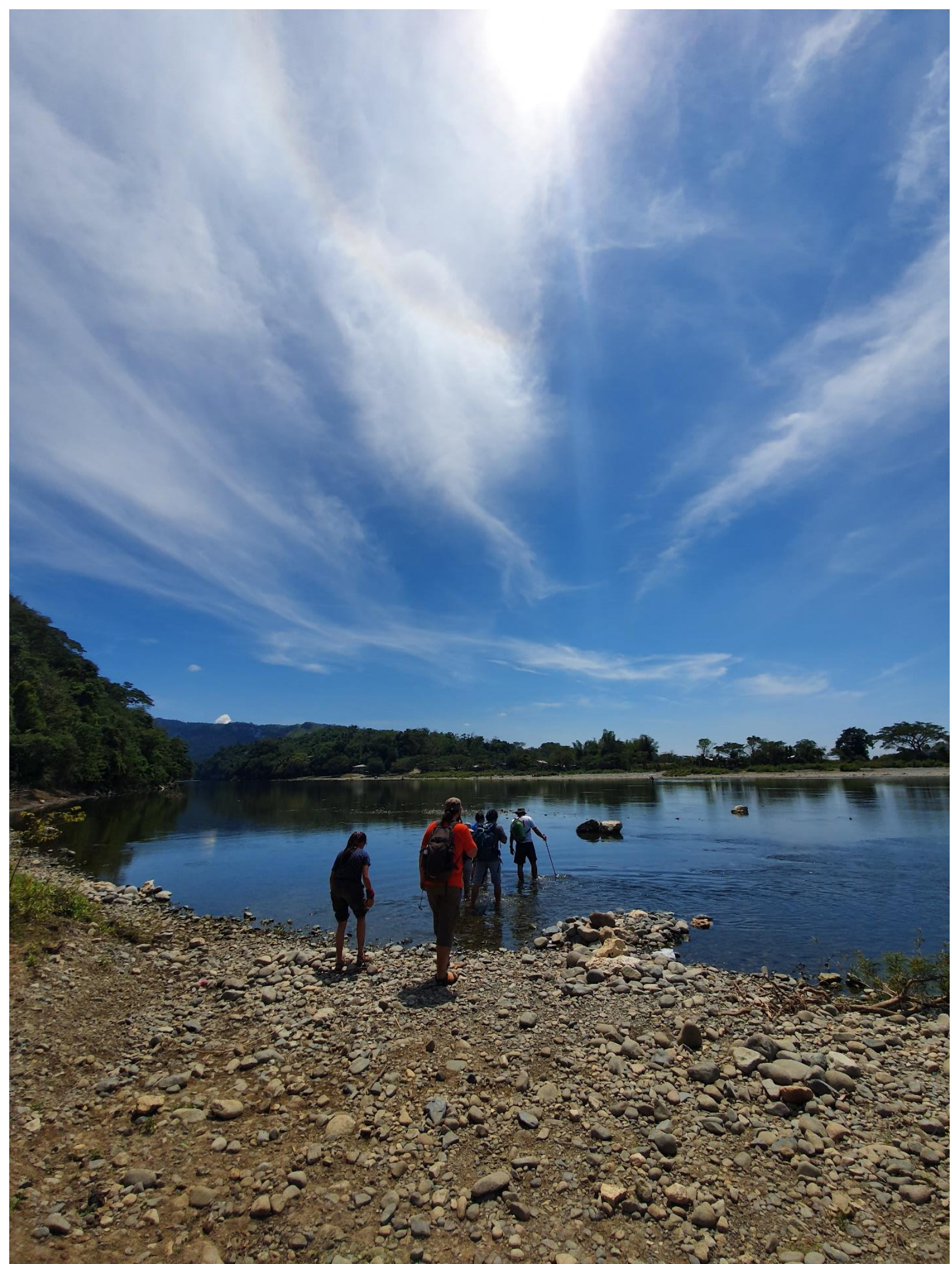

Fig. 17 Another way to cross the river was to walk further downstream, roll up our pants, and wade through the water. Some of us would do this in the afternoons if the tide was low. Source: KD Tantuico, 7 March 2020. 


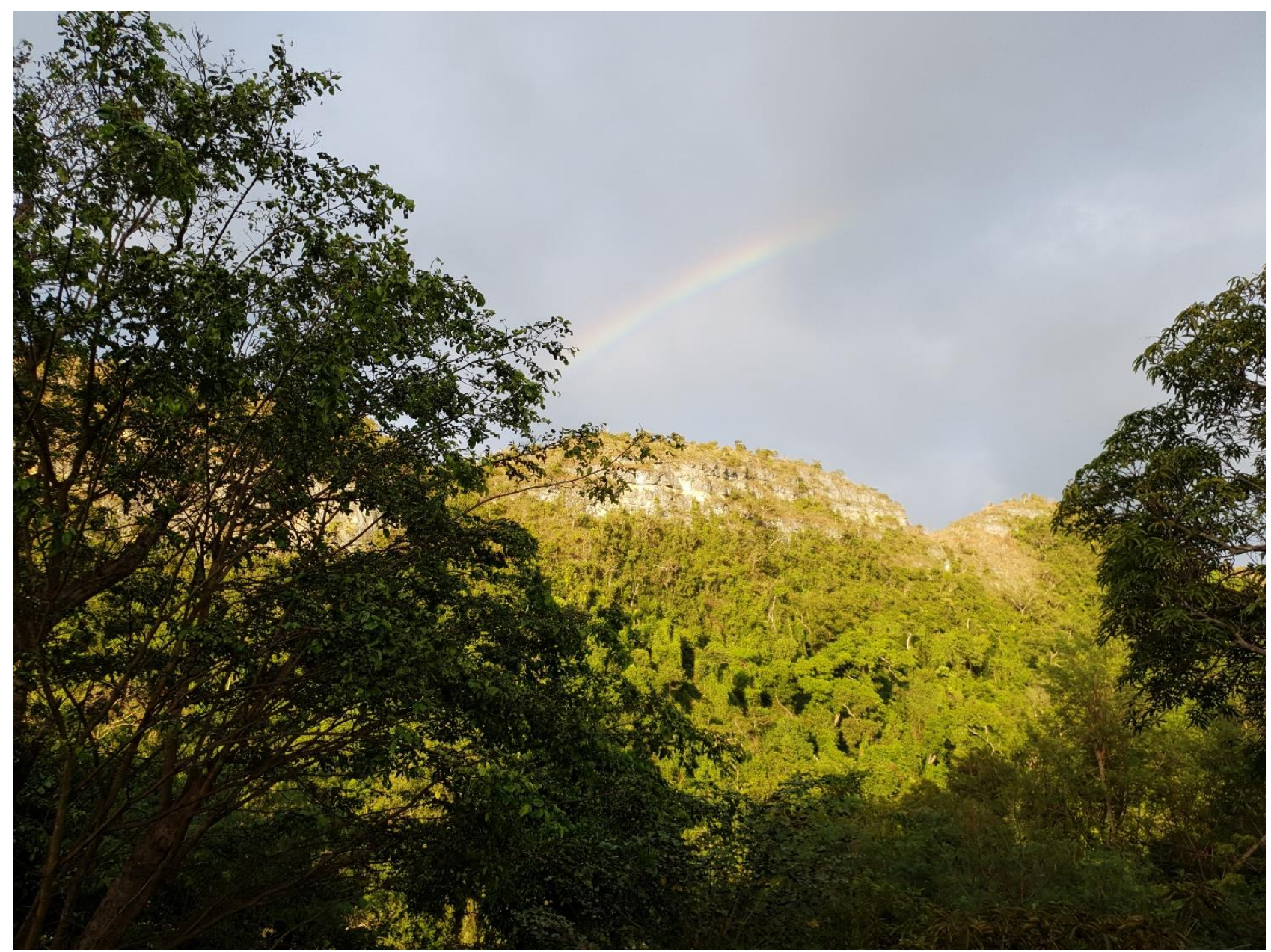

Fig. 18 The team's quarters was located on the opposite bank of the river, with a view deck overlooking the opposite ridge. Upon returning from the excavation site at Callao Cave, the team would rest while admiring the view. This photo was taken at 5:21 p.m. Source: KD Tantuico, 21 February 2020. 


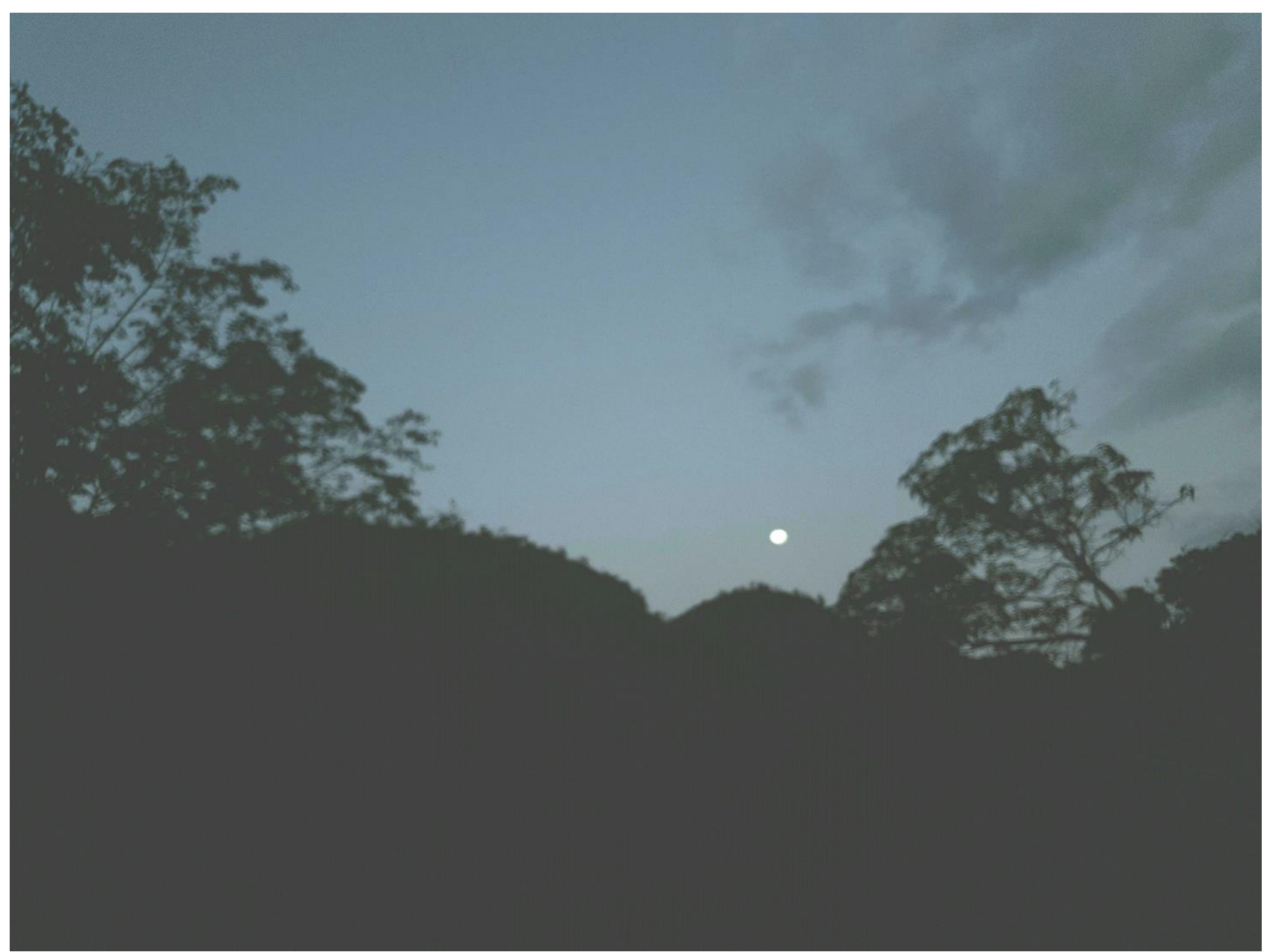

Fig. 19 The view deck was oriented towards the northeast. Although the sunset was not viewable in this area, the team would be treated to a view of the "moonrise" from behind the opposite ridge, starting from around 5:30 p.m. This photo was taken at 6:09 p.m. Source: KD Tantuico, 8 March 2020. 


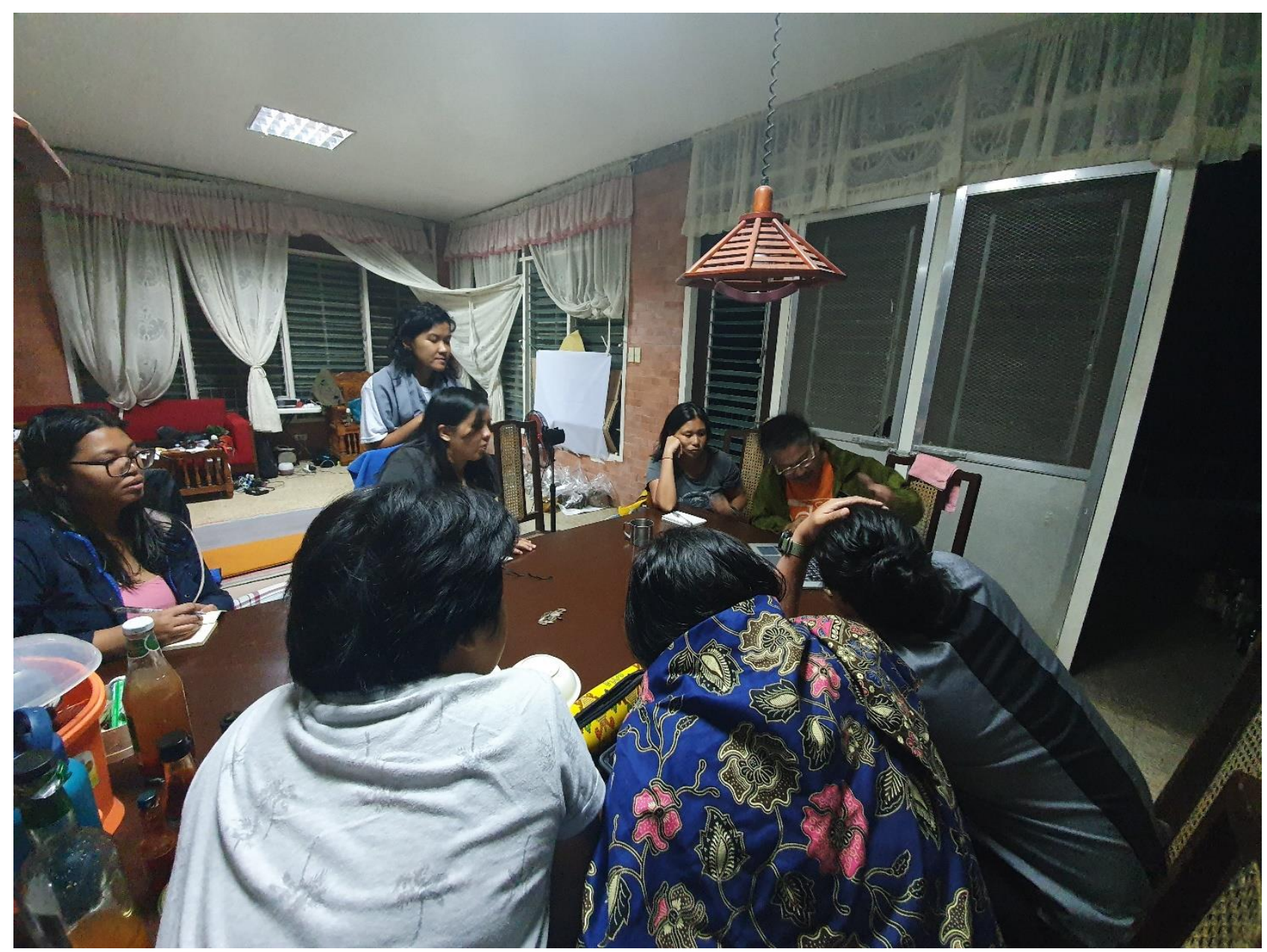

Fig. 20 In general, evenings would be for personal time. Occasionally, there would be team meetings to discuss the excavation as it progressed. Here, we see Professor Mijares and the excavation team explaining the objectives and adjustments for the last week of excavation. Source: KD Tantuico, 15 March 2020.

\section{The Excavation Proper}

For this year's re-excavation, the archaeologists opened two squares measuring 2 meters by 2 meters side-by-side at Callao Cave's main entrance. We aimed primarily to search for more fossilized human remains that could shed more light on the newly discovered Homo luzonensis Hominin species. This excavation made use of the spit method. A "spit" is an individual subdivision within the archaeological square, in which archaeological materials are situated. In other words, the spit method is a systematic way by which archaeologists remove sediments in order to uncover an archaeological assemblage. It is a method recommended for sites with numerous micro-vertebrates (Royer. 2014: 277-286).

Archaeological trowels were the main tool for removing sediments. The archaeologists recorded each spit in 5-centimeter increments. Artefacts were hand collected and sediment samples were collected in a one by one sample square in each main square. Dry and wet sieving was also conducted for sediment samples for older layers, starting from the Neolithic layer. Rapid excavation or "hataw" was also used when necessary. 


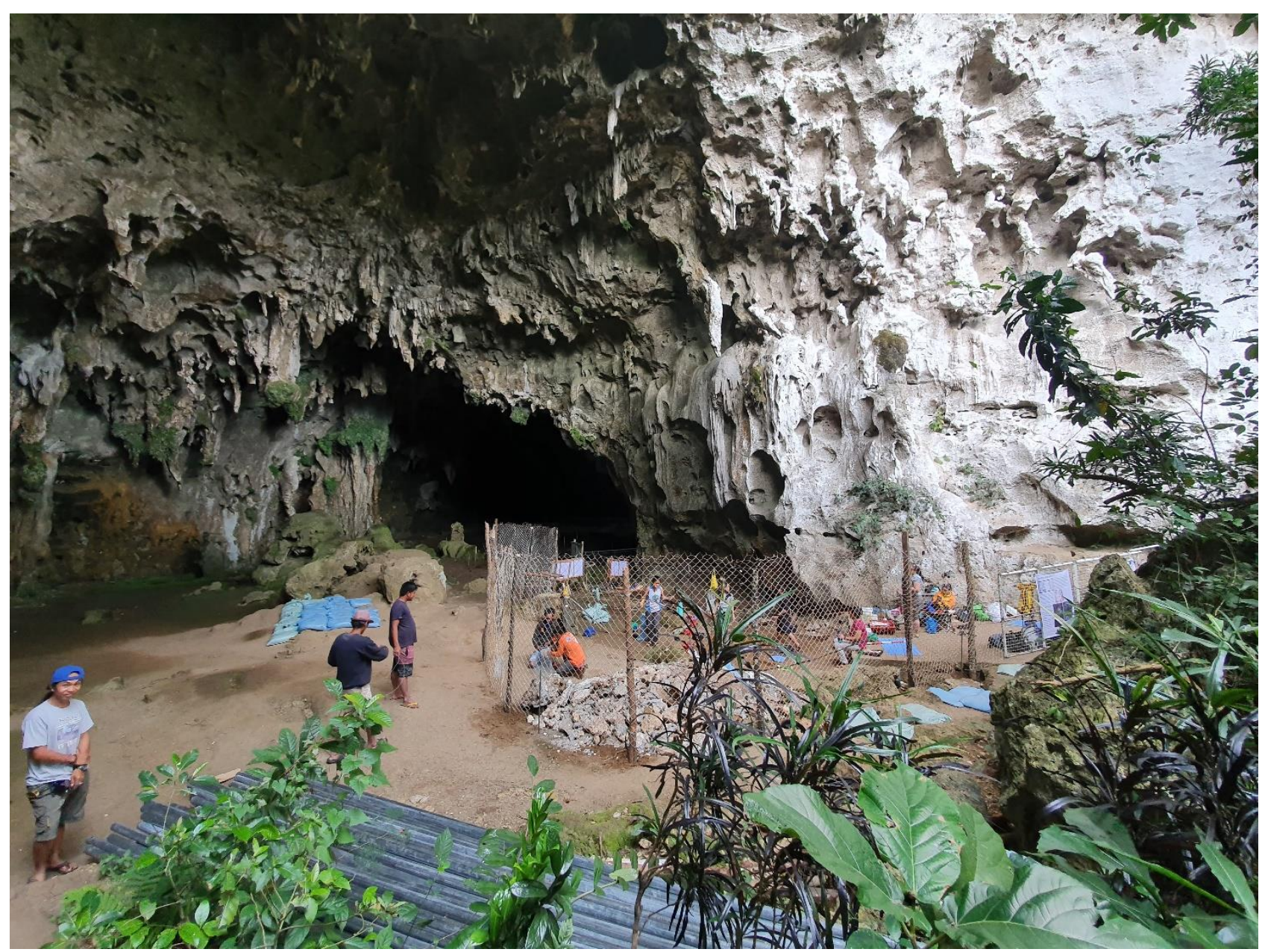

Fig. 21 A view of the excavation site during the first few days of excavation. The site was located at the entrance of Callao Cave. Since the Cave is a major tourist destination in the area, steel screen and wooden barriers were used to mark the site. Tourists were free to observe proceedings through the screen barriers. Source: KD Tantuico, 11 February 2020. 


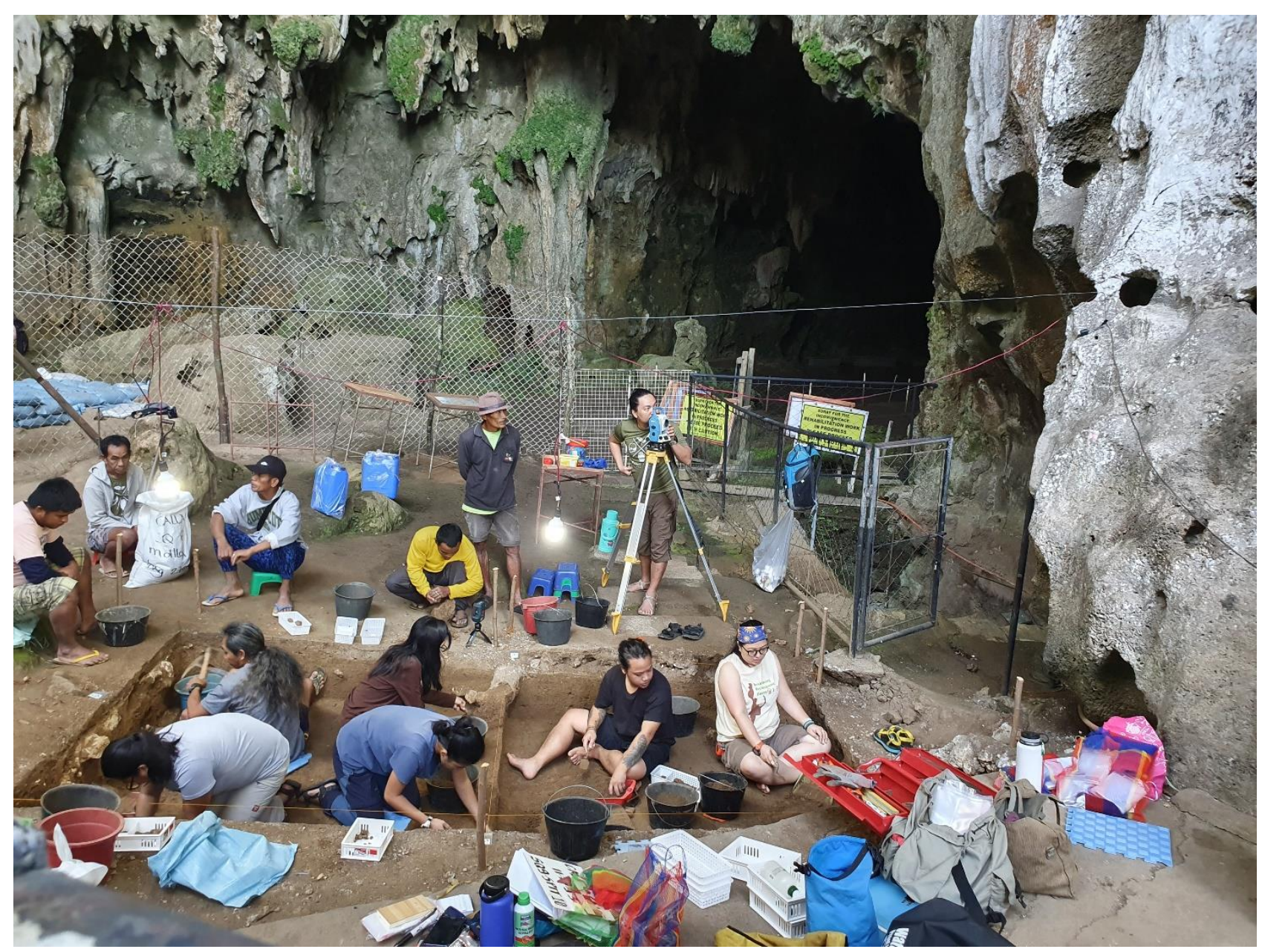

Fig. 22 Each square measured two meters by two meters. During the early stages of the excavation, a maximum of four archaeologists could work inside each trench. Each person occupied one corner. The archaeologists removed five centimeters of sediments from the entire square for each spit. Each spit was then photographed and drawn to scale on a recording form. Source: KD Tantuico, 14 February 2020. 


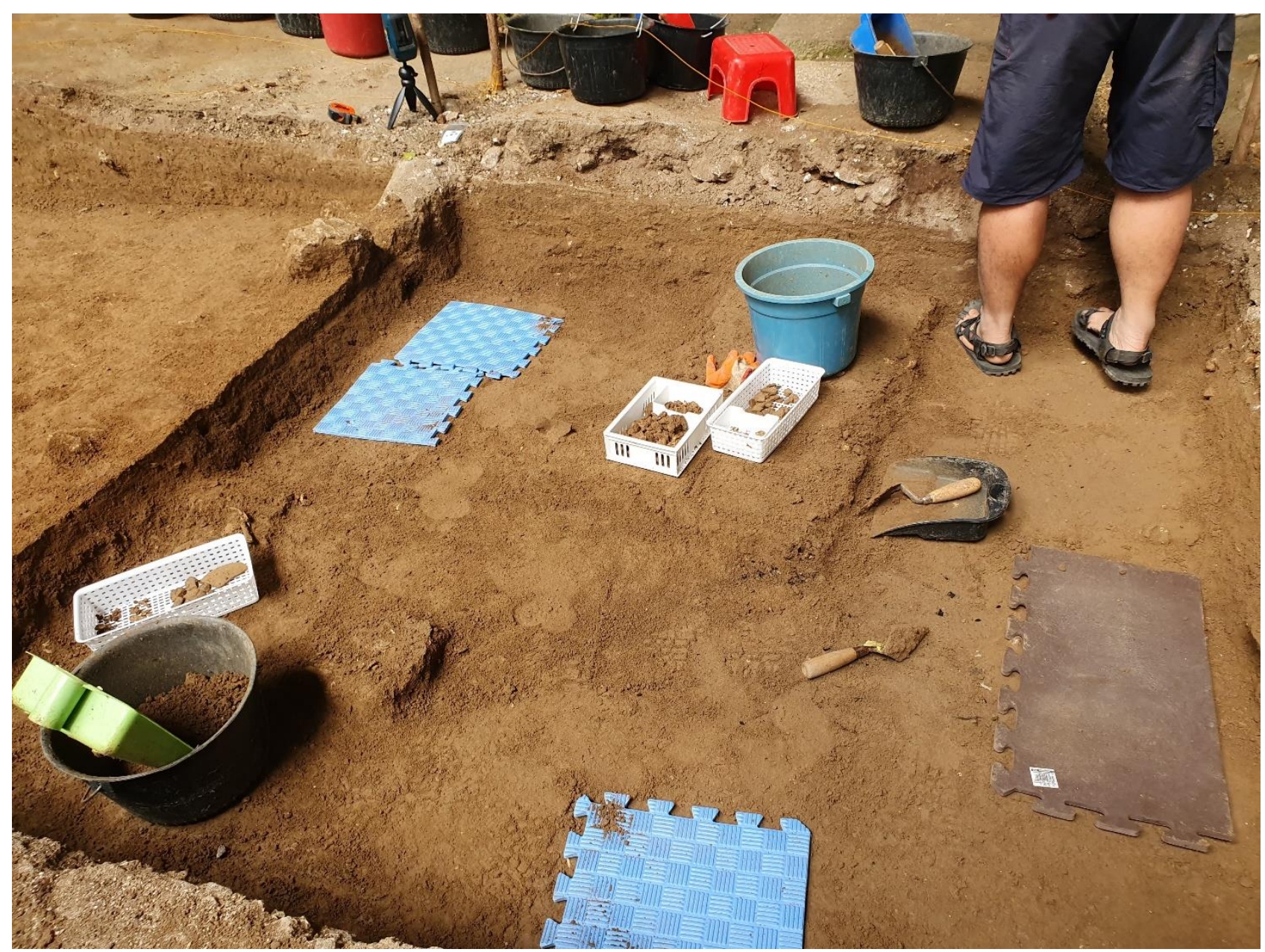

Fig. 23 Through the spit method of excavation, archaeologists use trowels to loosen sediments and scrape them into dustpans, and transferred to buckets. They would do this while kneeling on the ground. Rubber mats would cushion their knees. Artefacts such as earthenware sherds, animal and human bones, beads, seeds, and other cultural items would be hand collected and placed in plastic trays before being sorted and bagged at the end of the day. Each square would be photographed and drawn to scale every time five centimeters of sediments would be removed from each square. Each 5-centimeter increment would be considered a "spit" and labeled as "Spit 1," "Spit 2" and so on. Source: KD Tantuico, 13 February 2020. 


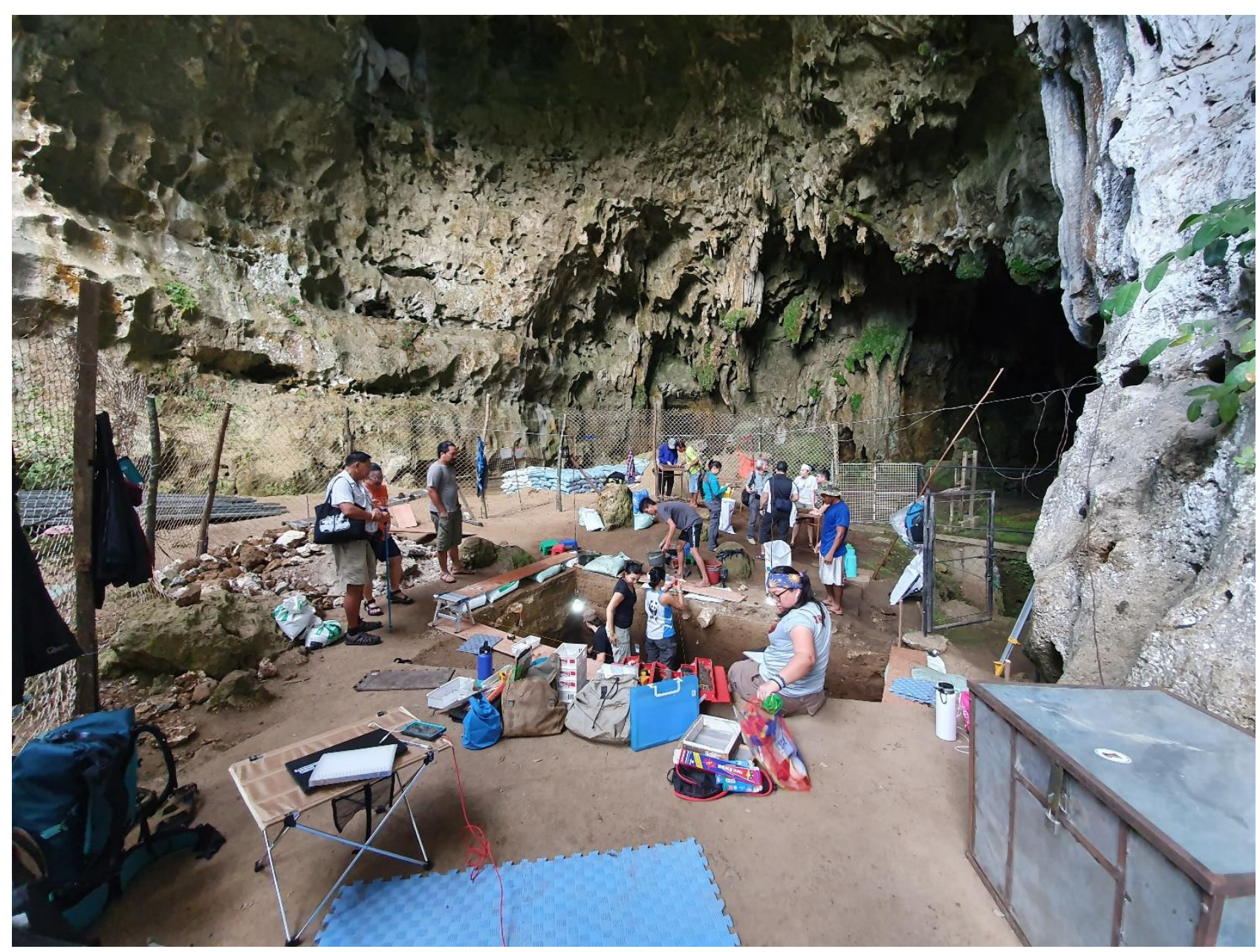

Fig. 24 By the third week of excavation, archaeologists had already reached a depth of more than one meter below the surface. Sediments were dry sieved to recover smaller artifacts that were unable to be detected in situ. In this photo, lead archaeologist Dr. Armand Salvador Mijares (second from left) and Dr. Eusebio Dizon (first from left) are seen supervising the excavation. Source: KD Tantuico, 25 February 2020. 


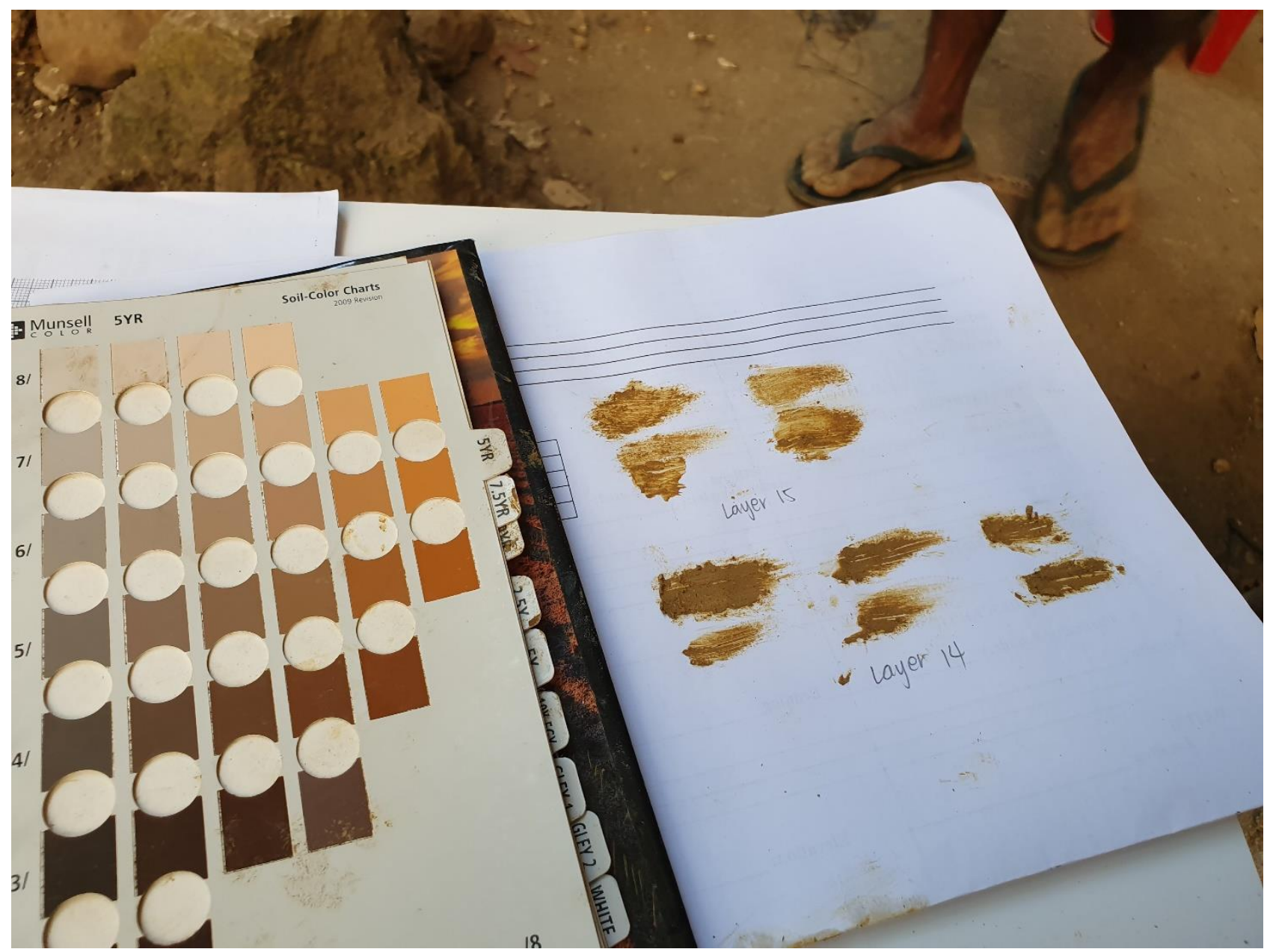

Fig. 25 Each sediment layer was described based on their color, texture, compactness and viscosity. The Munsell color chart was used to determine the sediment's specific shade. Moist sediment samples were blotted onto a paper and compared with reference shades on the Munsell Soil Color Chart. Source: KD Tantuico, 25 February 2020. 


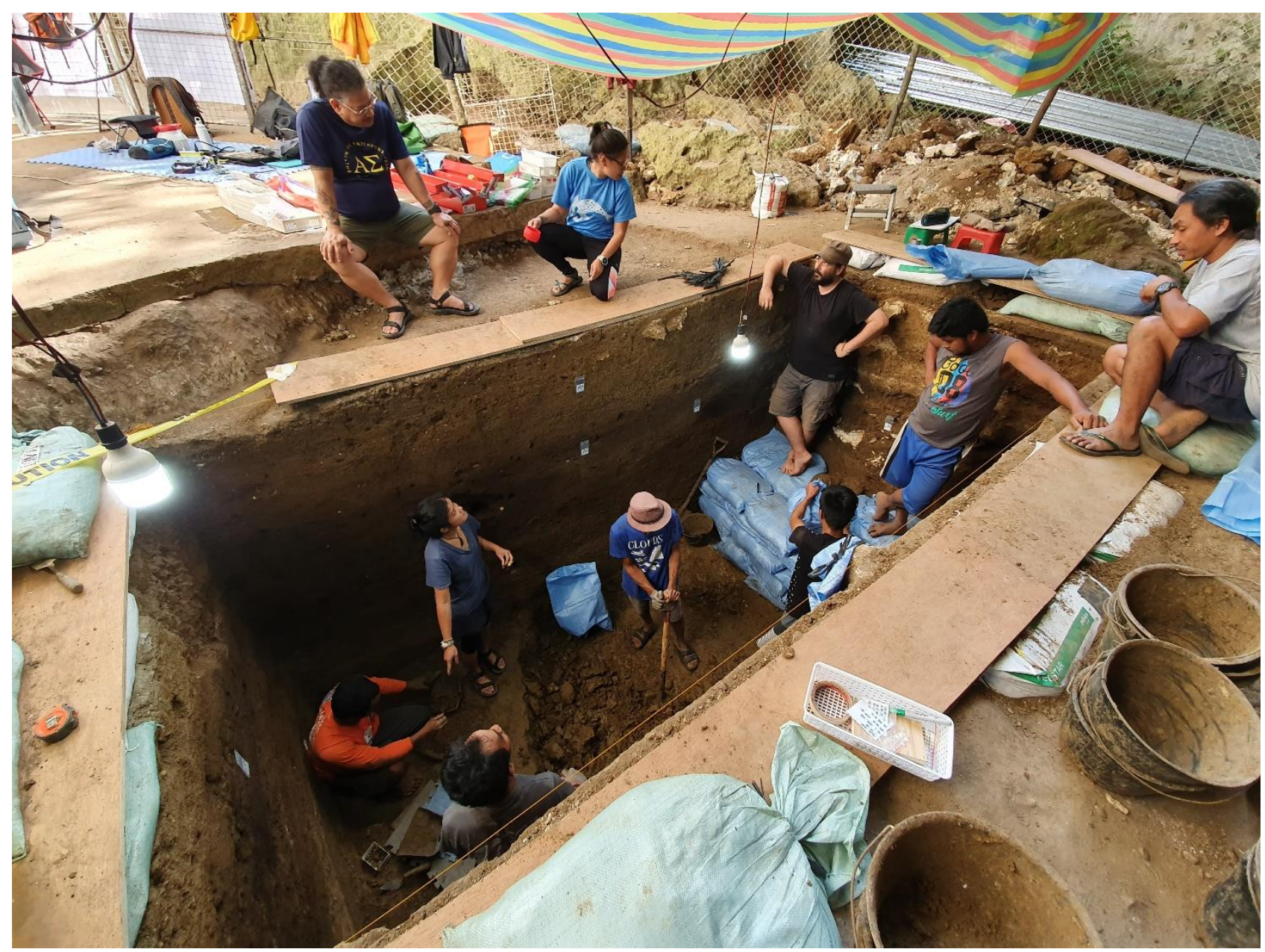

Fig. 26 Upon reaching around two meters below surface, the two squares were combined into one four by two-meter trench and excavated simultaneously. The trench's edges were lined with plywood beams to prevent loose soil from collapsing. Sacks full of sieved sediments were placed in the western portion to serve as an entry and exit point. Archaeologists were encouraged to enter the trench barefoot as a precautionary measure for unexcavated delicate artefacts, if any. Source: KD Tantuico, 28 February 2020. 


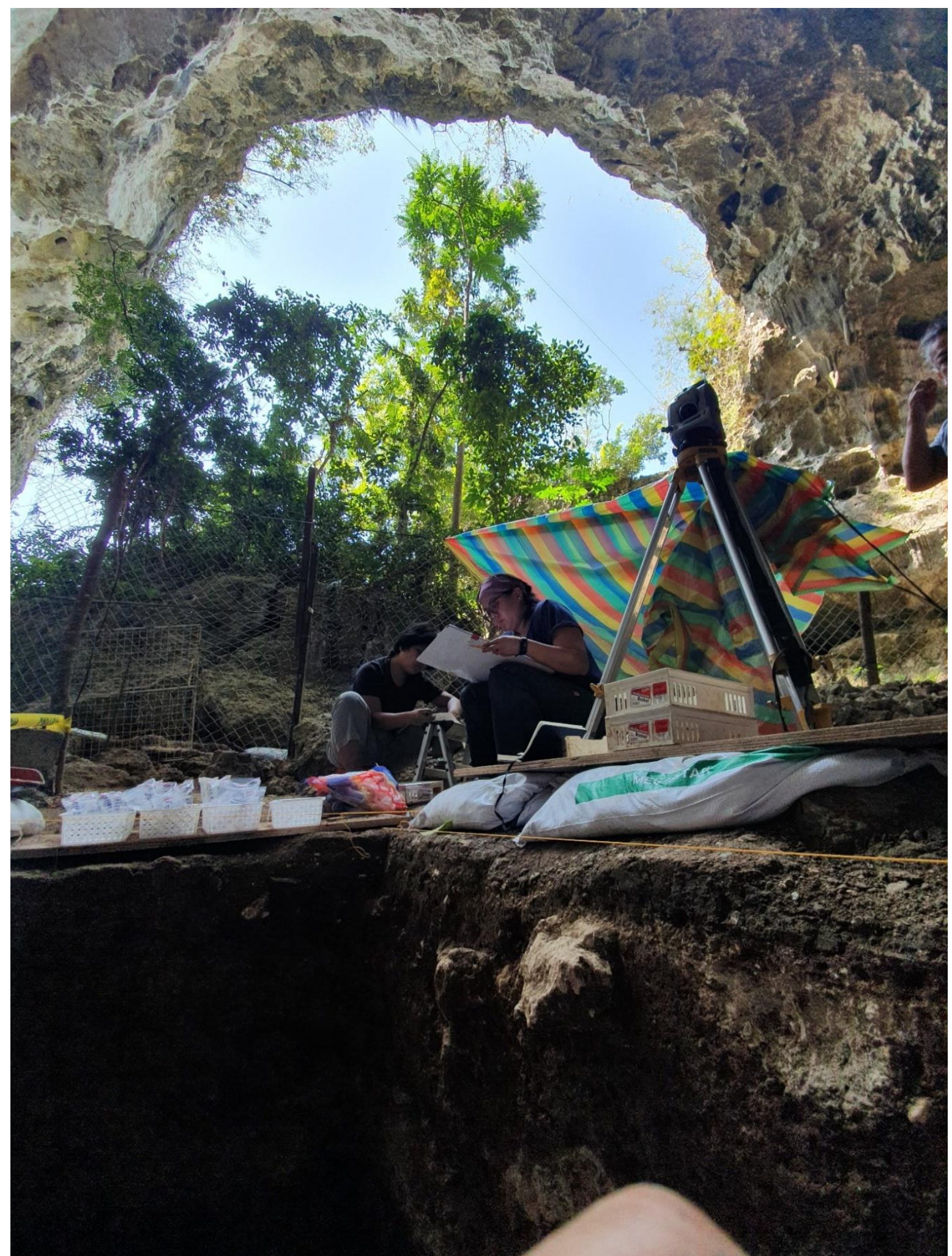

Fig. 27 The X and Y coordinates of recovered chert flakes and other stone tools were plotted using the Total Station Theodolite. Stone tool were bagged individually and labeled as soon as the coordinates were recorded. Identical digital information was also stored in the Total Station Theodolite. All bagged artefacts were placed in trays until they were transported back to the archaeologists' quarters on the same day. Source: KD Tantuico, 19 March 2020. 


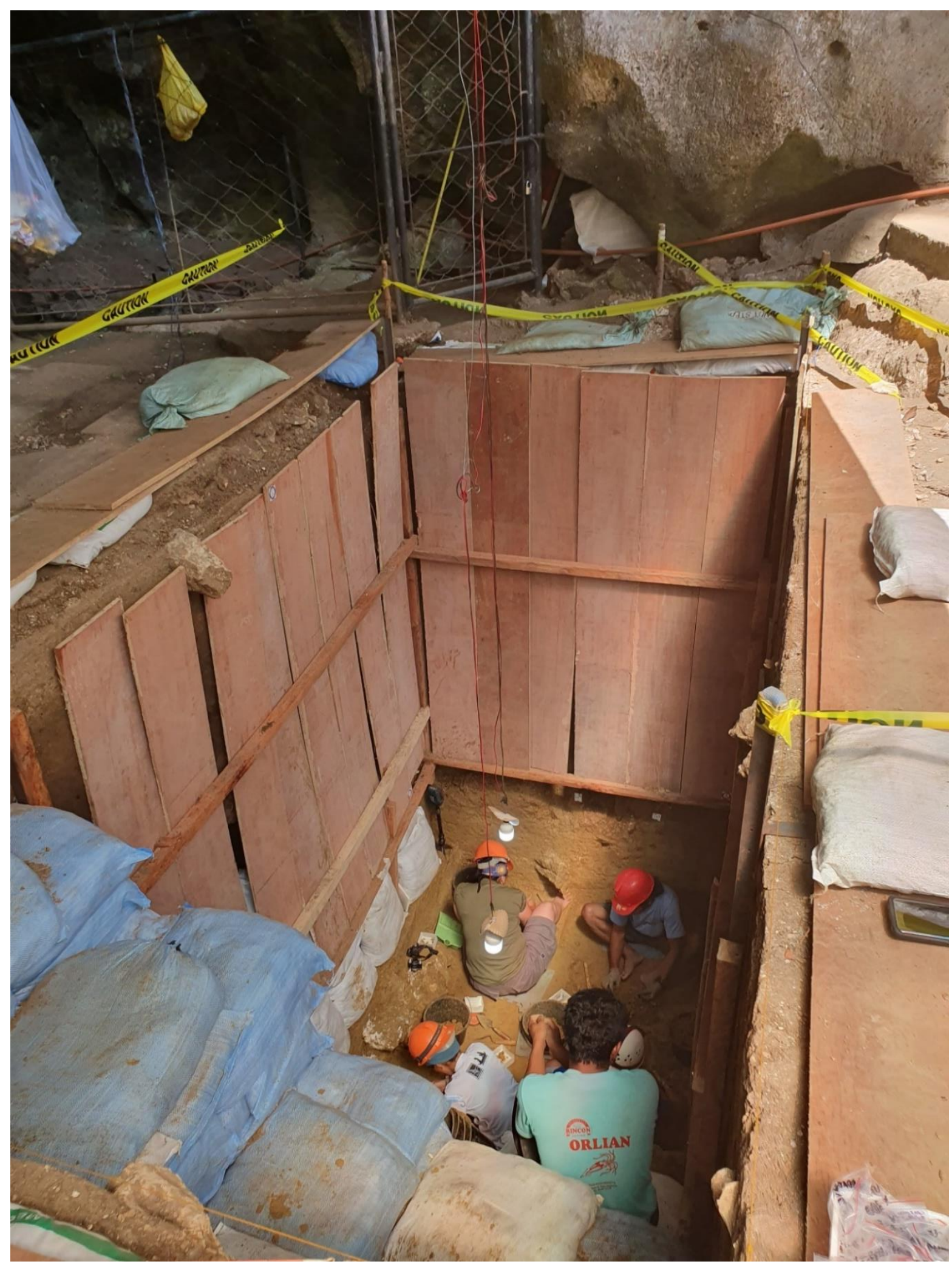

Fig. 28 Wooden shoring was installed during the last two weeks of excavation, when the team had already reached two meters below surface. This provided support for the trench's three exposed walls. Sediment samples on each of the walls were recorded prior to this installation. By this time, a maximum of only four archaeologists could work in the $4 \times 2$ - meter trench. Hard hats were also used as safety precautions. Source: KD Tantuico, 20 March 2020 . 


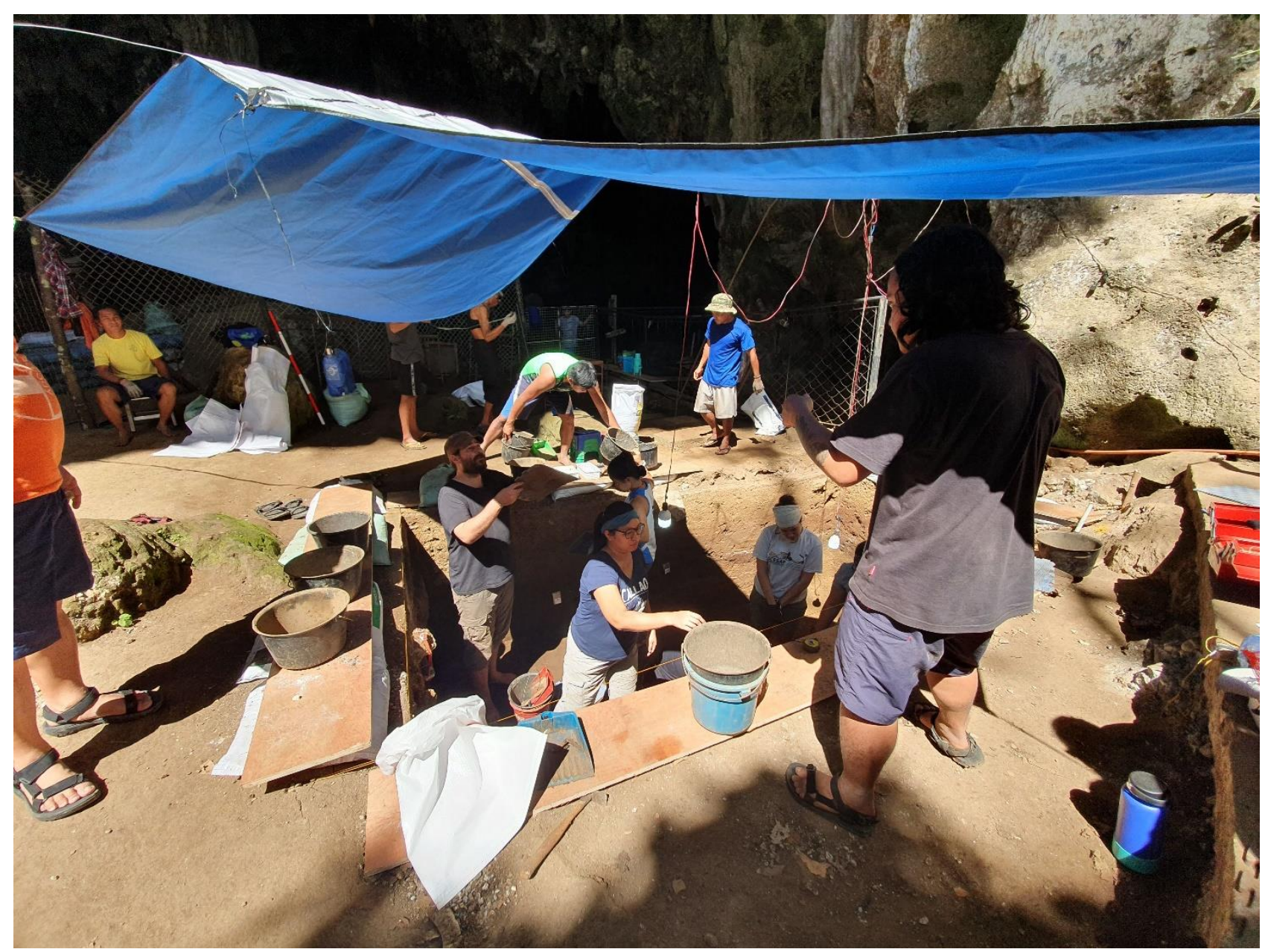

Fig. 29 In the early afternoons, a plastic tarpaulin would be installed above the excavation site to ease the direct sunlight on the archaeologists. Source: KD Tantuico, 25 February 2020. 


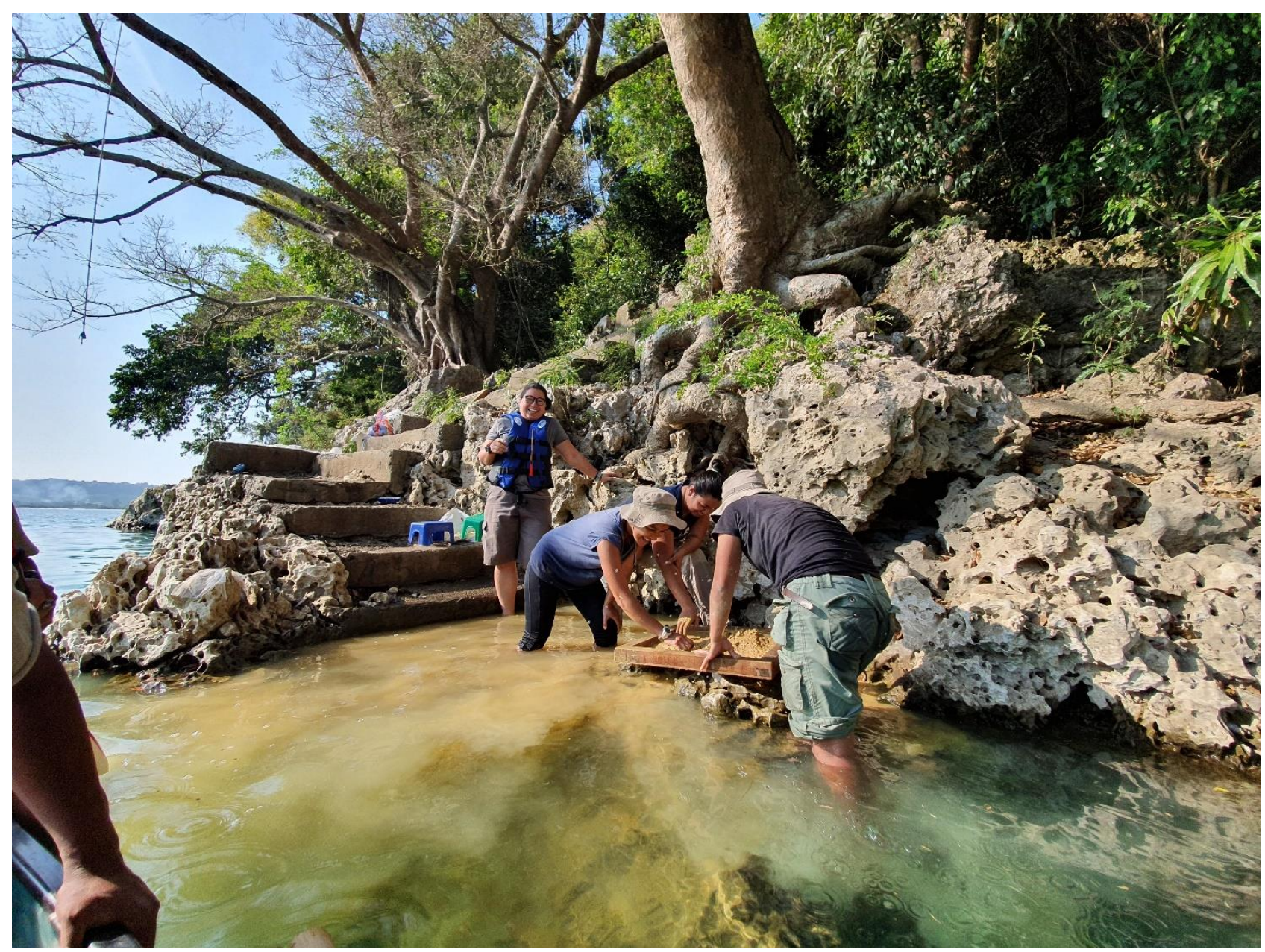

Fig. 30 Sediments from the lower clay layers were also wet sieved to ensure the collection of miniscule artefacts that were embedded in the older clay sediments. This was done at the bank of the Pinacanauan River. Source: KD Tantuico, 20 March 2020.

\section{Dealing with Artefacts: Cleaning, Preliminary Analysis and Inventory}

In archaeological excavations, artefacts play a significant role in the study of archaeological sites. They are the cultural materials left behind by prehistoric humans. Through these tangible objects, archaeologists are able to analyze the material culture of previous civilizations. This adds weight to the responsibility of archaeologists to exert utmost care while archaeologically extracting artefacts from the assemblage. In practice, however, it is recognized that even an experienced archaeologist's best efforts cannot guarantee that ancient artefacts will remain intact during the excavation.

Under the Heritage Law (Republic Act No. 1006), the National Museum of the Philippines is responsible for the conservation and management of archaeological artefacts and other significant movable cultural property that pertain to archaeology and anthropology (14 ${ }^{\text {th }}$ Congress. 2010: Article VIII Section 31(e). Pursuant to a Memorandum of Agreement, the University of the Philippines' Archaeological Studies Program is also authorized to manage and store artefacts for purposes of analysis.

After being collected either by hand or through dry or wet sieving from the archaeological assemblage, the artefacts obtained from the excavation site would be sorted first according to which 
spit they were obtained from, and second, according to type: earthenware, animal bones, human bones, shells and special artefacts such as beads and other anthropological materials. They would then be washed in an area by the team's quarters. This was done by gently brushing the artefacts with a toothbrush and rinsing in a bucket of water.

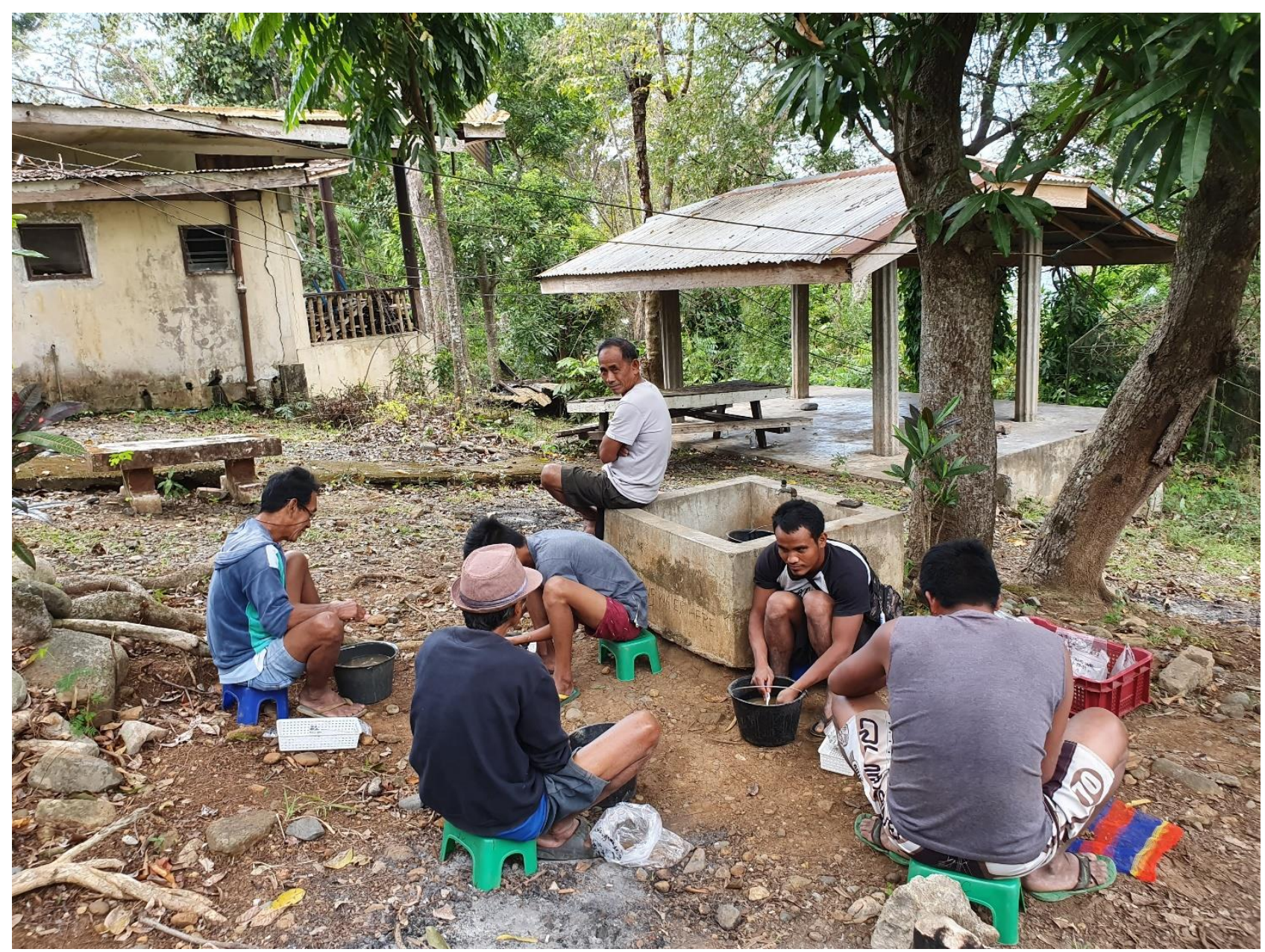

Fig. 31 The team's laborers-technicians would assist the team in pot washing artefacts in a washing area near the team's quarters. Source: KD Tantuico, 22 February 2020. 




Fig. 31 After washing, the artefacts would be laid out on canvass to dry. Source: KD Tantuico, 22 February 2020. 


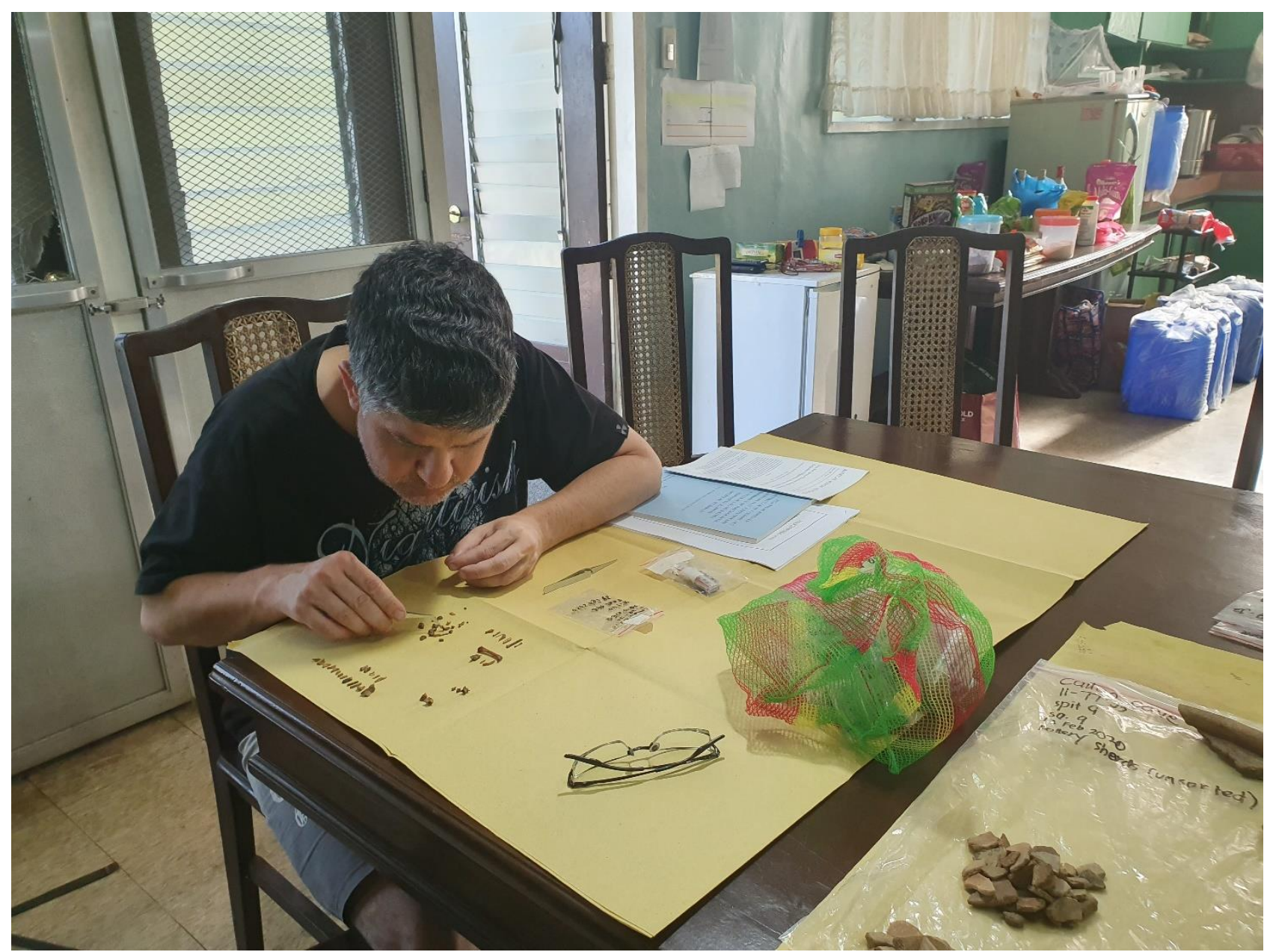

Fig. 33 Dry artefacts would be ready for preliminary analysis if a specialist was available to preliminarily identify them. Here, Dr. Juan Rofes, a Spanish citizen from Peru who specializes in animal bones is identifying microvertebrates obtained from the site. He is currently an Associate Professor at the University of the Philippines Archaeological Studies Program. Source: KD Tantuico, 29 February 2020. 


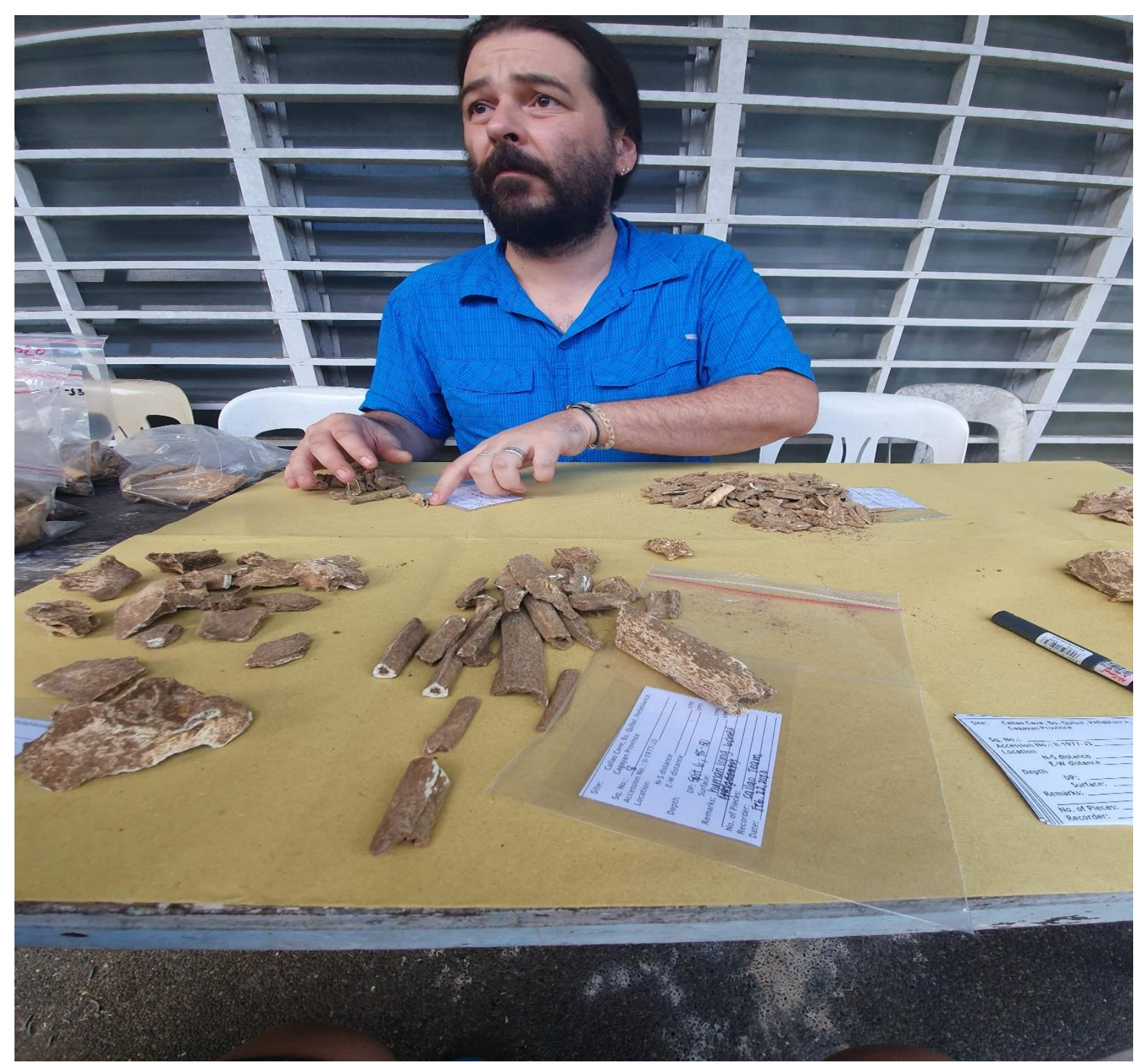

Fig. 34 French Paleoanthropologist Dr. Florent Detroit, who specializes in human bones sorts human remains obtained from the excavation. He is the primary author of the international publication that identified the new Hominin species Homo luzonensis from human remains previously obtained from Callao Cave. Source: KD Tantuico, 22 February 2020. 


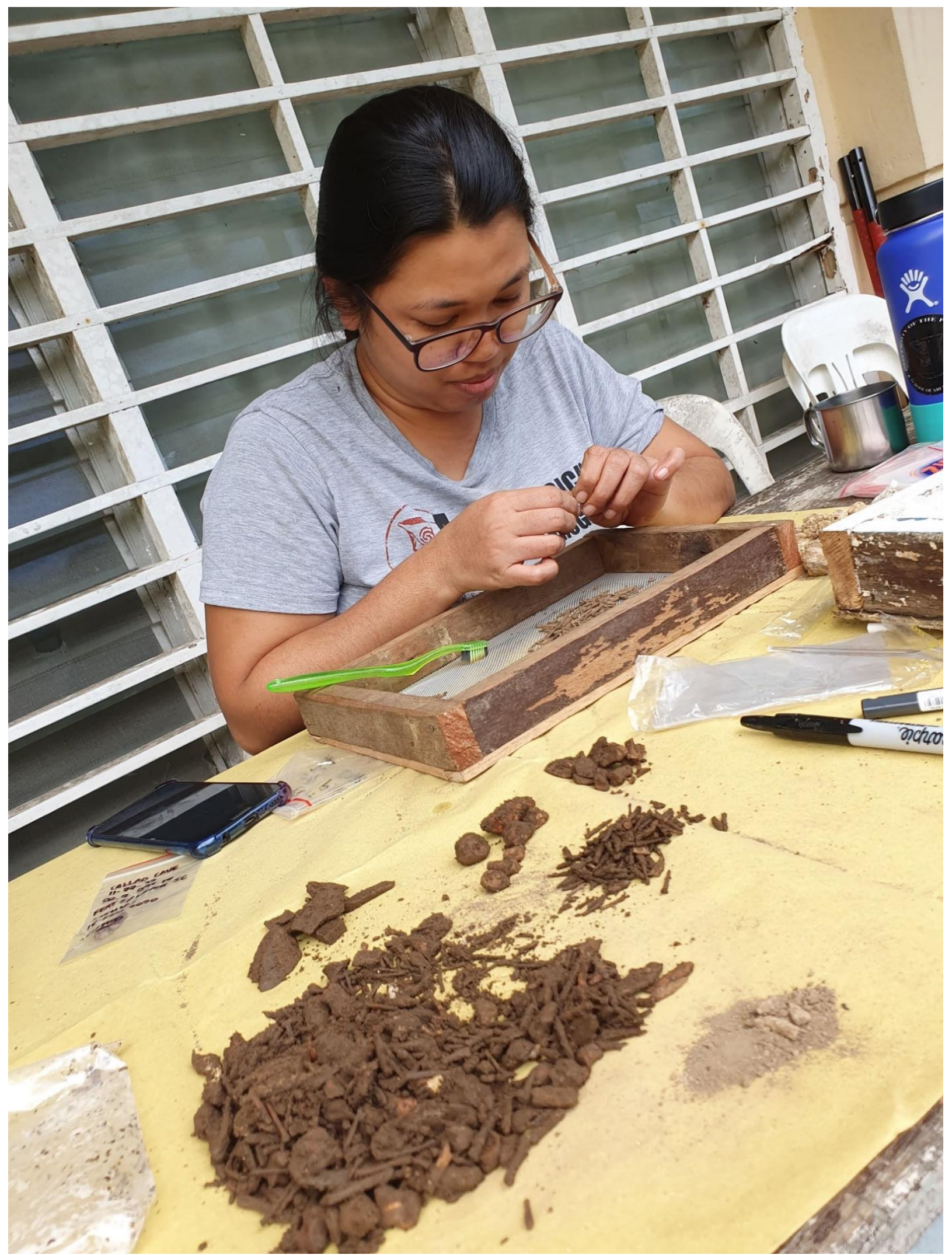

Fig. 35 Cleaning very small animal bones can be very tedious, as they are usually covered in hardened sediment. Here, microvertebrate remains are being cleaned one by one so as to be more identifiable. Source: KD Tantuico, 22 February 2020. 


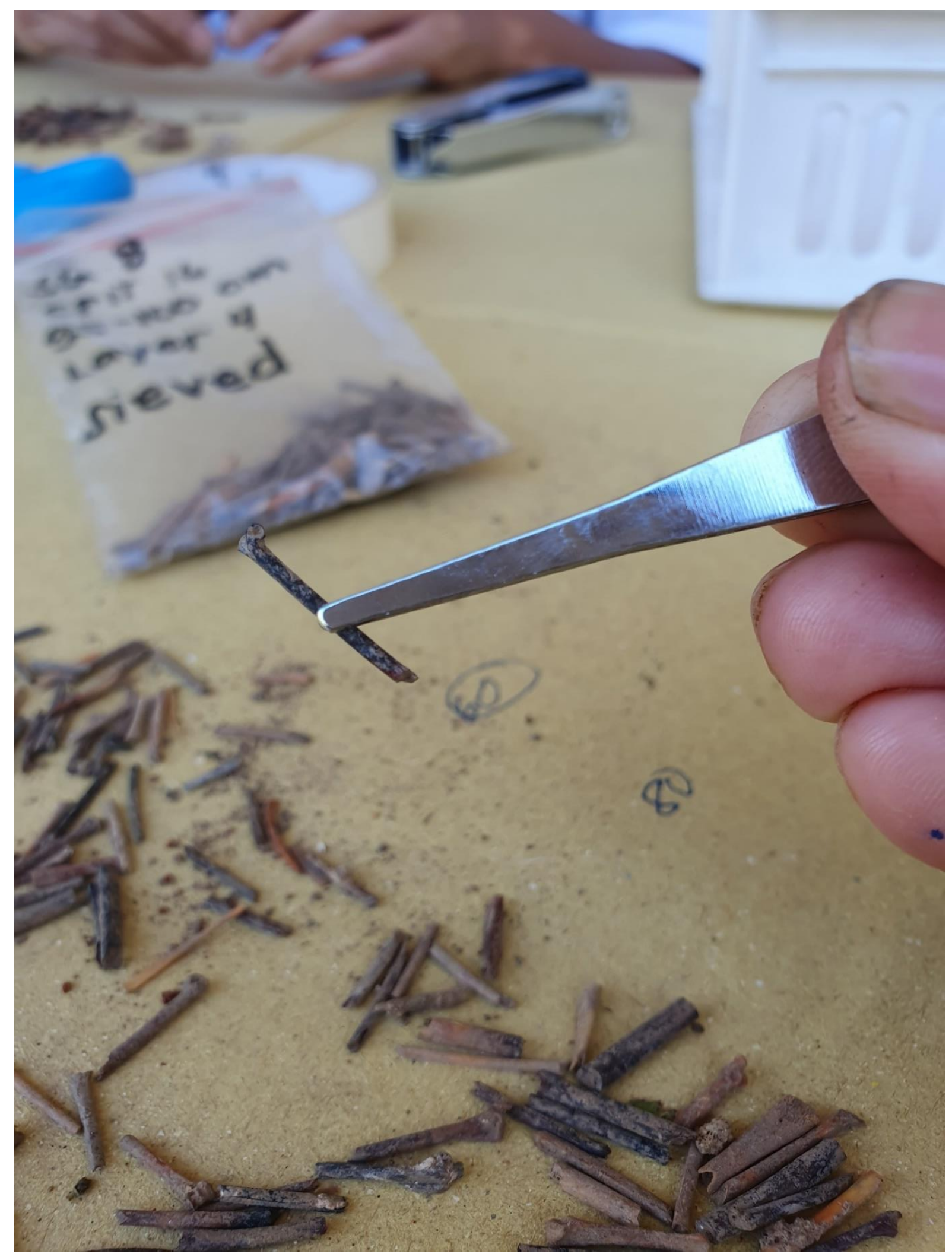

Fig. 36 There was a numerous amount of microvertebrate remains in the site. They were obtained either by hand or were sieved. Here, tweezers were used to handle very small long bone fragments. Source: KD Tantuico, 5 March 2020. 
Once artefacts are sorted, washed and dried, they are ready to be given an accession number, to be bagged and placed in storage crates for transportation back to the University of the Philippines in Quezon City, Metro Manila, which is around 500 kilometers away from the excavation site. The archaeologists must ensure that each artefact is properly bagged and stored in such a way that they will not deteriorate while being transported.

Accession numbers are assigned for purpose of tracking and inventory. Accession codes are assigned by the National Museum of the Philippines based on the site's location in this format: Region Number-Year first excavated-Alphanumerical label. This site's accession code was "II1977-J3", plus the next number assigned to each artefact chronologically (National Museum of the Philippines (n.d.).

During that last three weeks of excavation, when only a maximum of four archaeologists would be able to excavate the trench, the team was divided into a group for excavating and a group for accessioning. Each group had equally important tasks. Under the Heritage Law, archaeological and ethnographic materials are considered as presumed Important Cultural Property. As such, they are protected from destruction and modification $\left(14^{\text {th }}\right.$ Congress of the Philippines. 2010. Article III Section 5). Thus, the archaeologists must exert maximum efforts to ensure the integrity and preservation of the artefacts from the time they are obtained until they are turned over to either the National Museum or the University of the Philippines' Archaeological Studies Program, depending on the Excavation Director's prior arrangements.

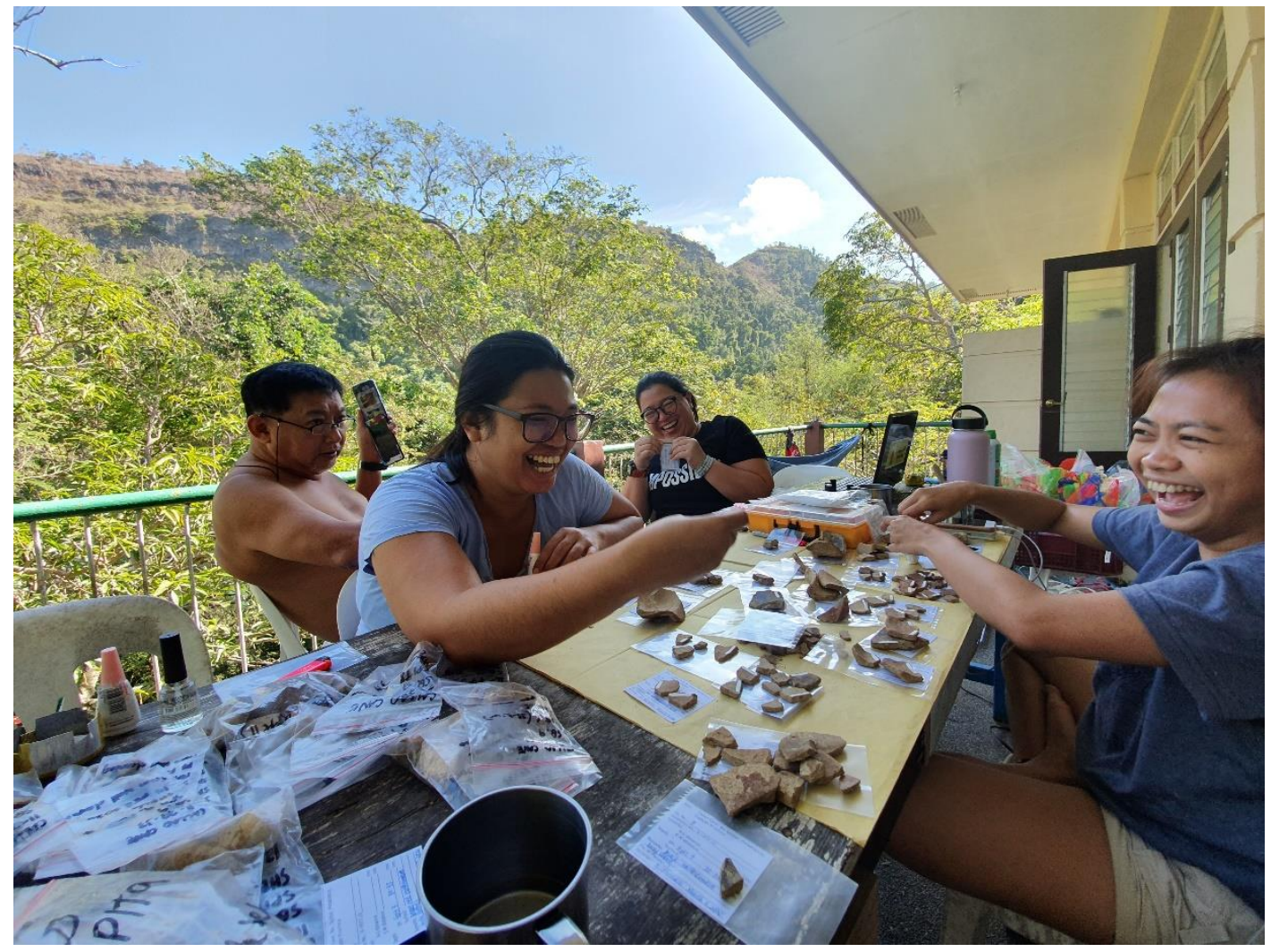

Fig. 37 All smiles while accessioning with a view at around 9:00 a.m. Source: KD Tantuico, 3 March 2020.

\section{Weekend Activities}

For our team of archaeologists, weekends would be as productive as weekdays in terms of activities. On Saturdays, the excavation would ensue until lunch time, and from 1:00 p.m. until 4:00 
p.m., the archaeologists would either be pot washing, housekeeping or in the market buying supplies. Sundays would be everyone's free day, but there would be optional excursions that everyone was welcome to join.

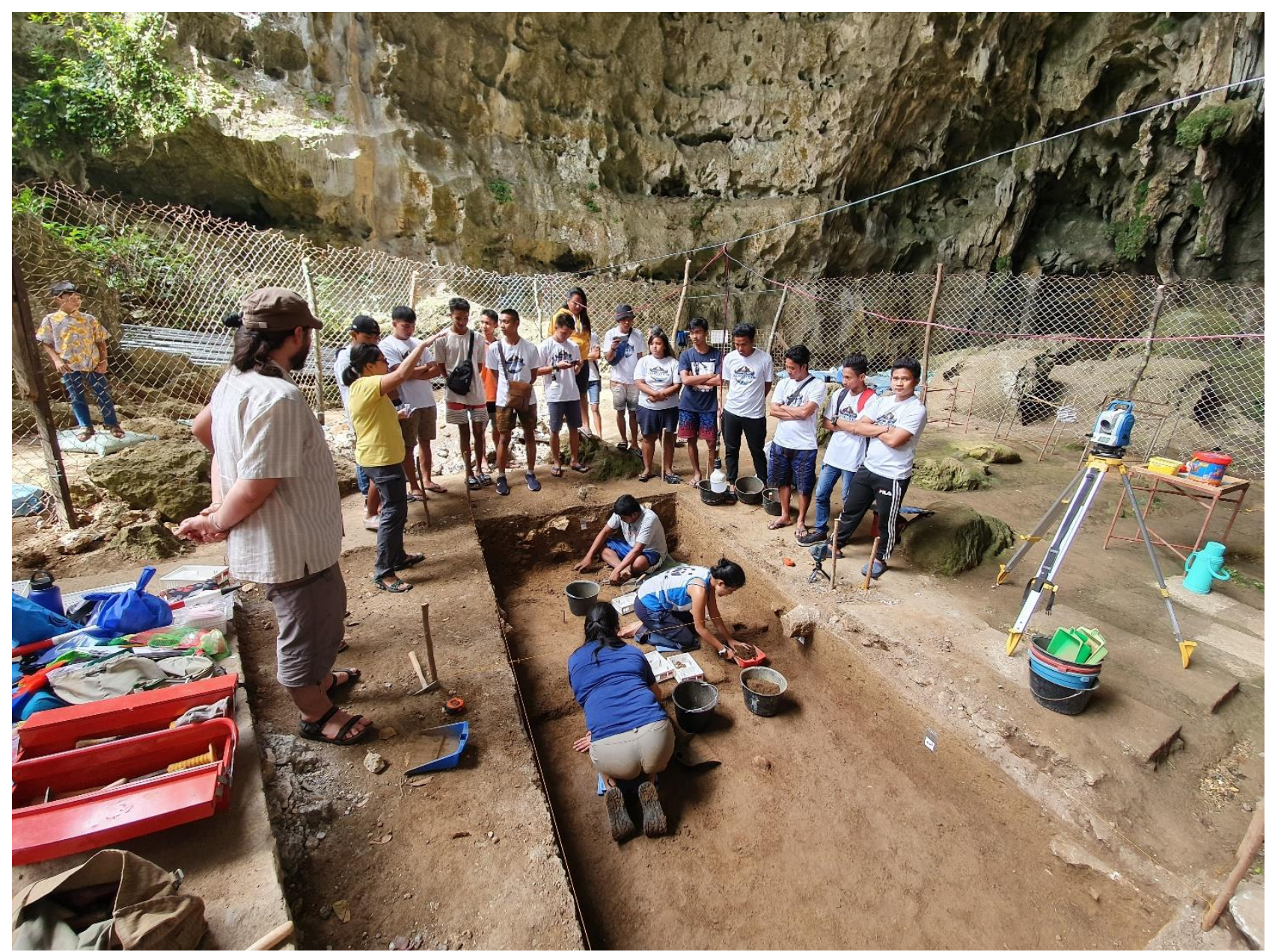

Fig. 38 On the first Saturday of the excavation, the Provincial Tourism Office organized a symposium for the tour guides of Callao Cave. We showed them the excavation site and explained the recent findings in Callao Cave so as to increase their knowledge on the subject matter. This activity aimed to heighten community involvement and awareness on the archaeological heritage of Peñablanca and Cagayan Province. Source: KD Tantuico, 15 February 2020. 


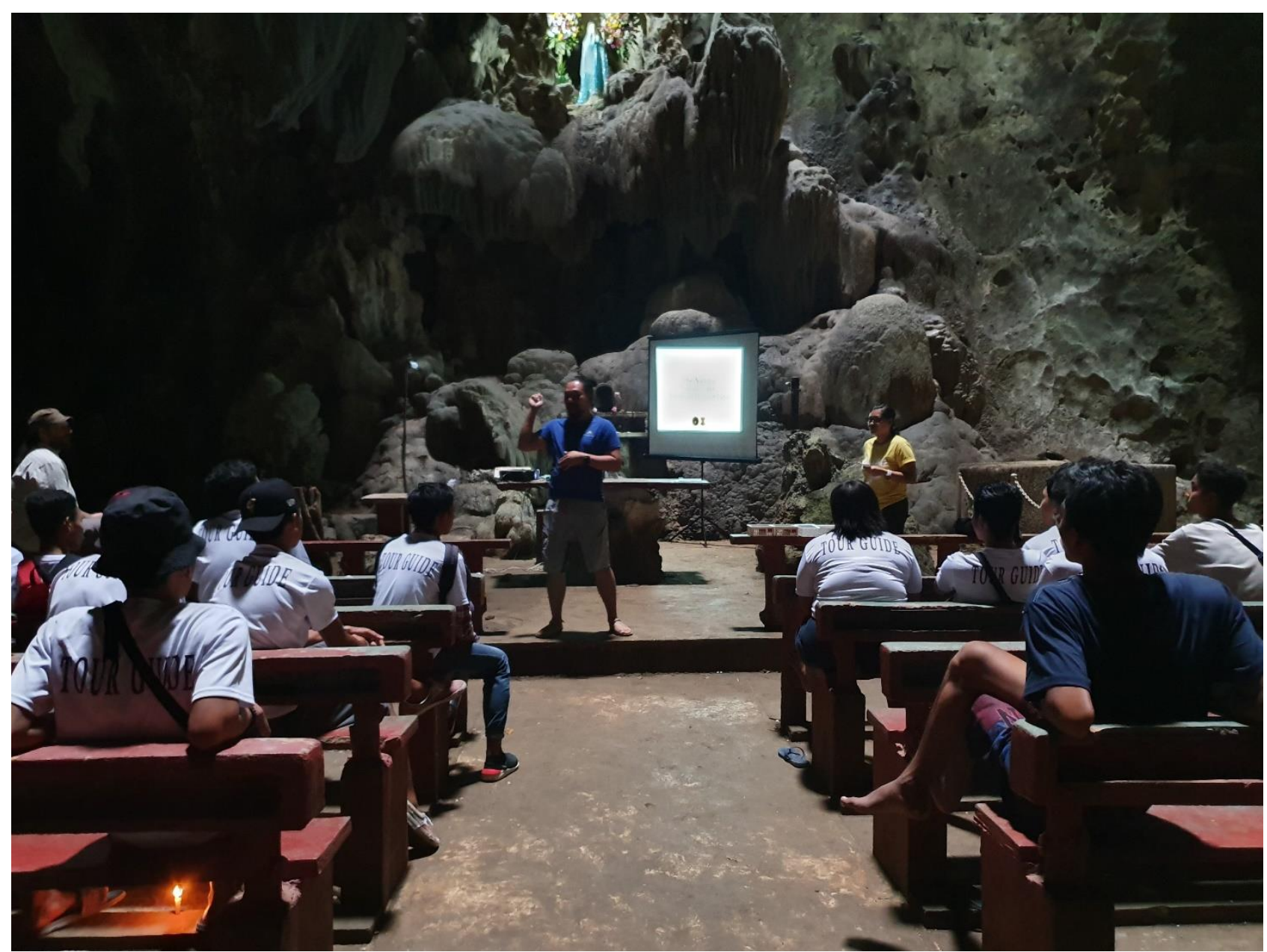

Fig. 39 Apart from showing the tour guides the excavation site and explaining basic archaeological methods, the archaeologists also conducted short lectures on the recent breakthrough findings at Callao Cave, and how it has made an impact on current lessons in history and social studies. Other topics included the geomorphology of the site, the laws that protect Callao Cave from destruction, and the role they play in protecting Callao Cave. These discussions aimed to improve the tour guides' understanding of the site so that they may impart more knowledge to the tourists at Callao Cave. Source: KD Tantuico, 15 February 2020. 


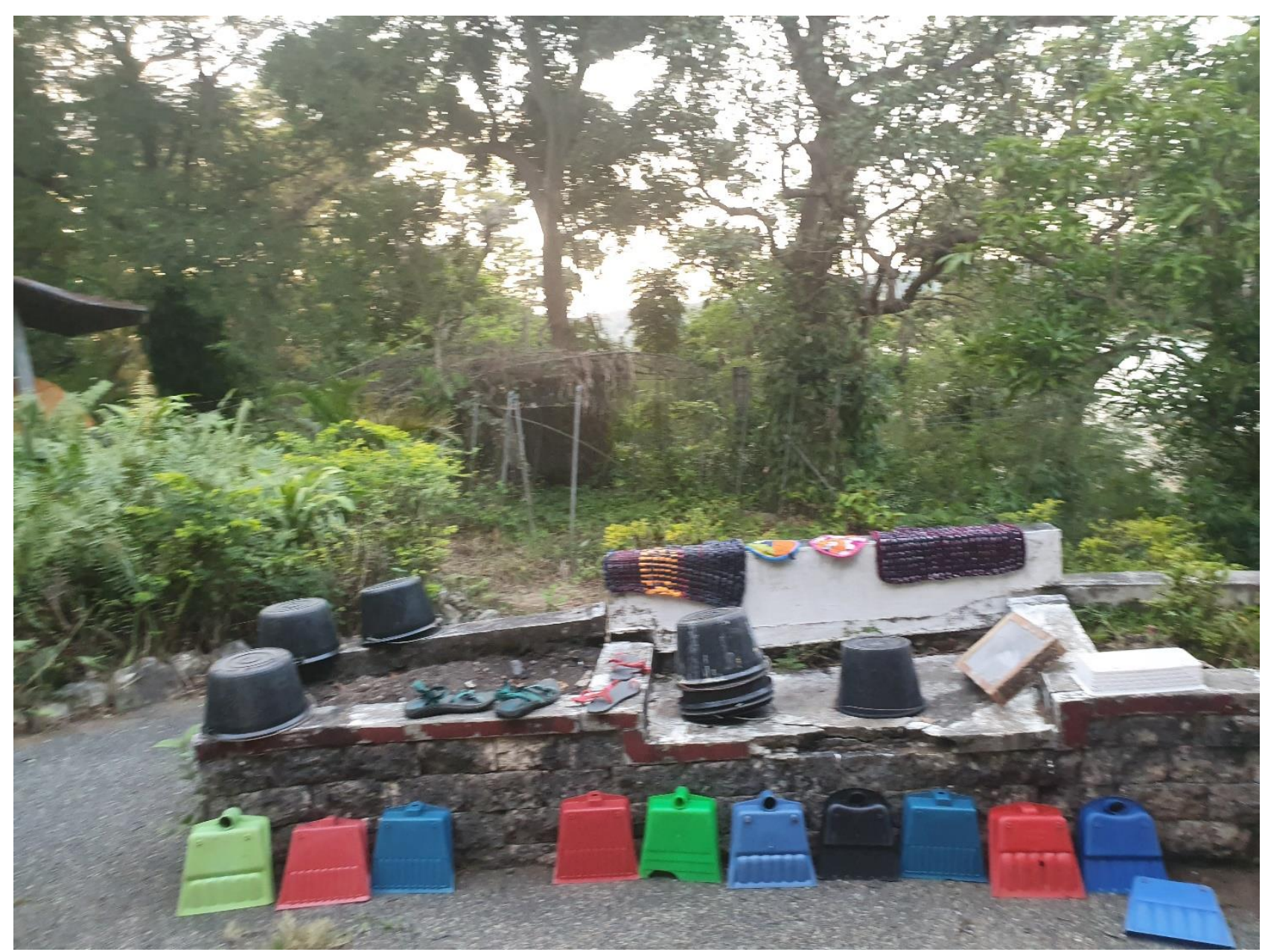

Fig. 40 Weekends would also be a good time to clean our equipment. Dustpans and buckets would be used to remove the sediments from the squares and transport them to the dry sieving area. The sieved sediments would again be placed in buckets to be transferred to sacks and stored until backfilling them at the end of the excavation. The sediments tend to harden at the bottom of the buckets and at the edges and in the dustpans' small gaps. Thus, the buckets. Dustpans and even trowels would be washed during weekends. Source: KD Tantuico, 29 February 2020. 


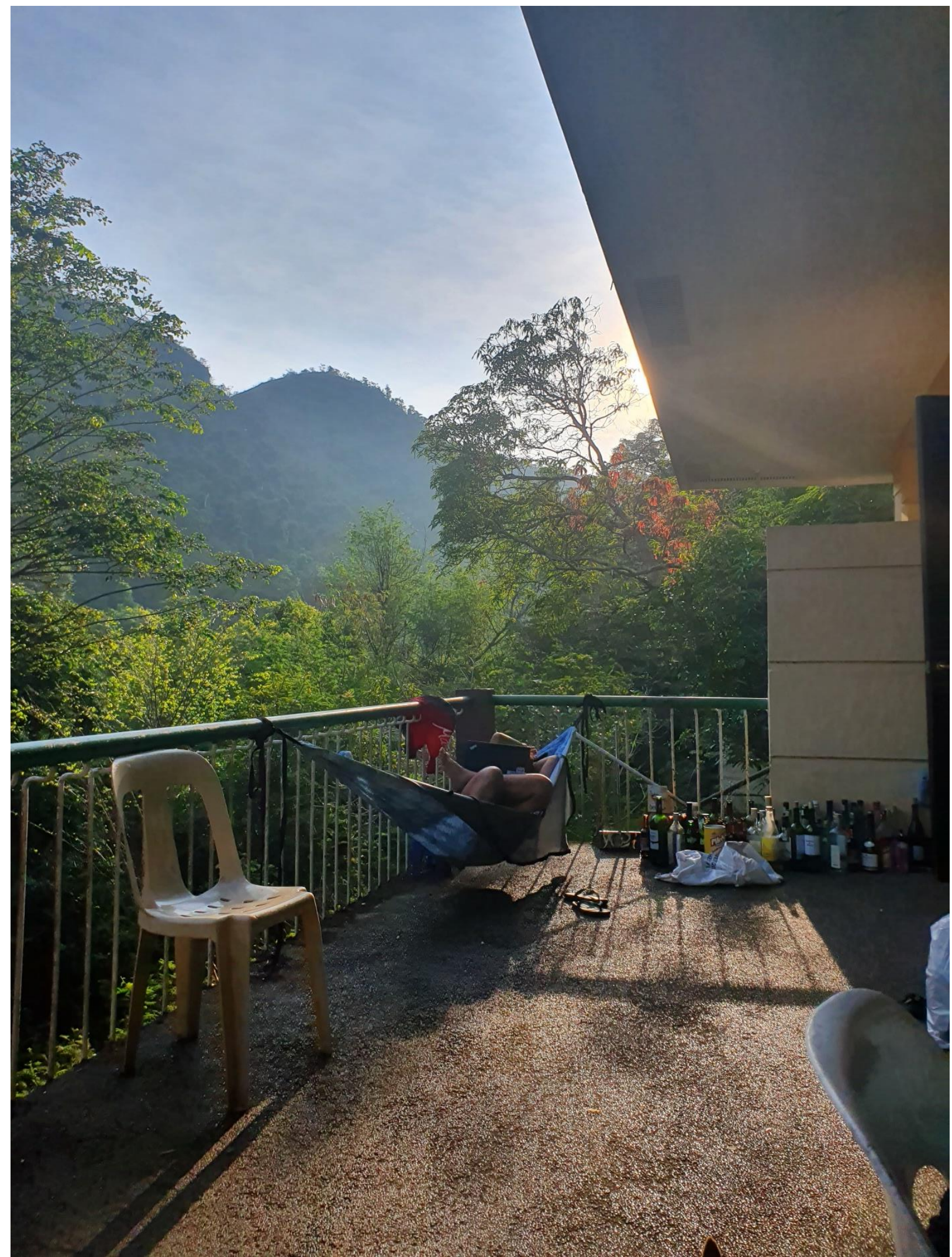

Fig. 41 Sundays, on the other hand, would be free days. We would lounge around on hammocks while watching movies. We could enjoy the view of the sunrise. Sundays were always very relaxing. These days were enough to recharge us for the work week ahead. Source: KD Tantuico, 15 March 2020. 


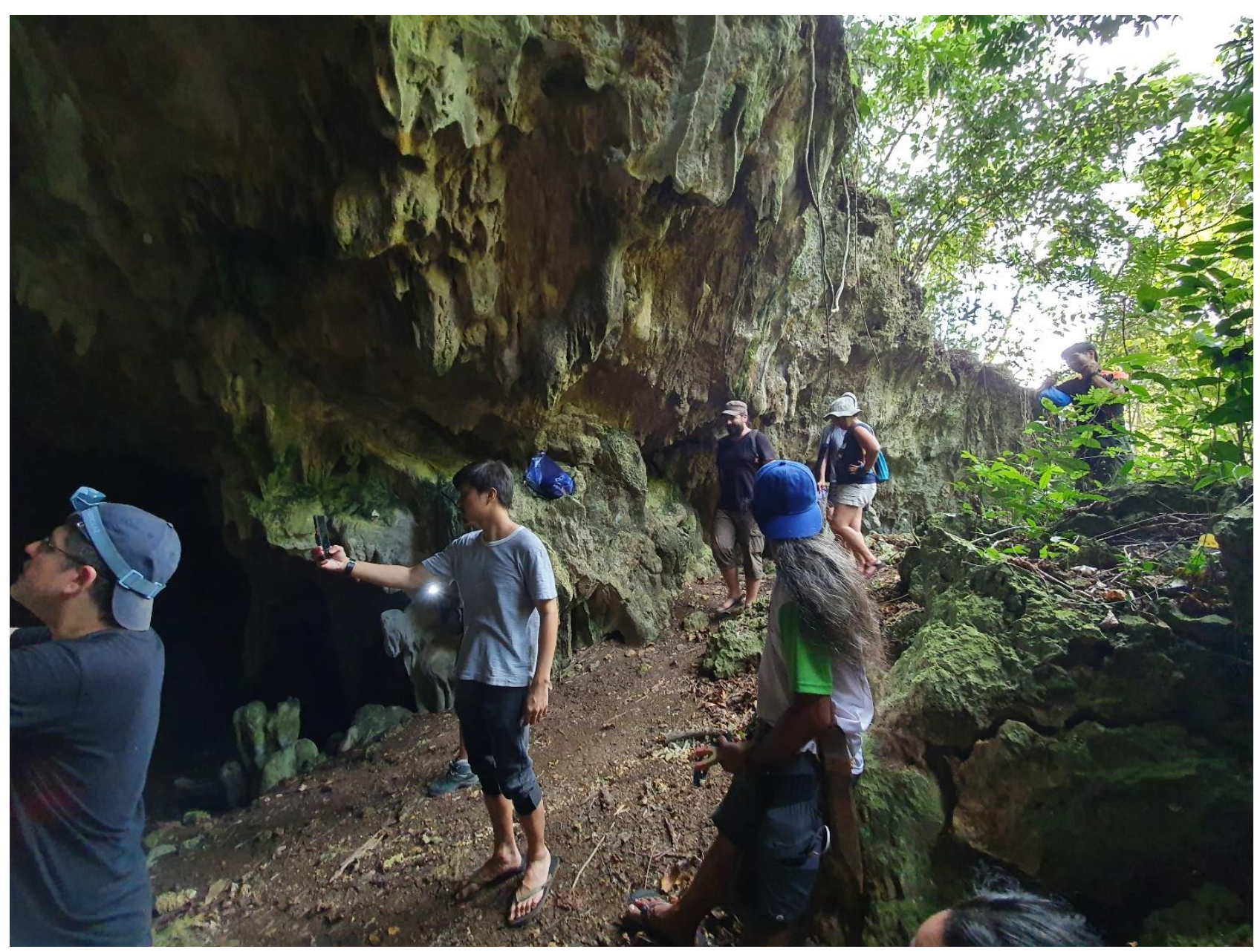

Fig. 42 On one Sunday, some of us went on a cave survey to nearby Rabel Cave. This Cave was first excavated by the National Museum in the 1980s. Here, we see the small group of archaeologists documenting the entrance of the cave before entering. Source: KD Tantuico, 29 February 2020. 


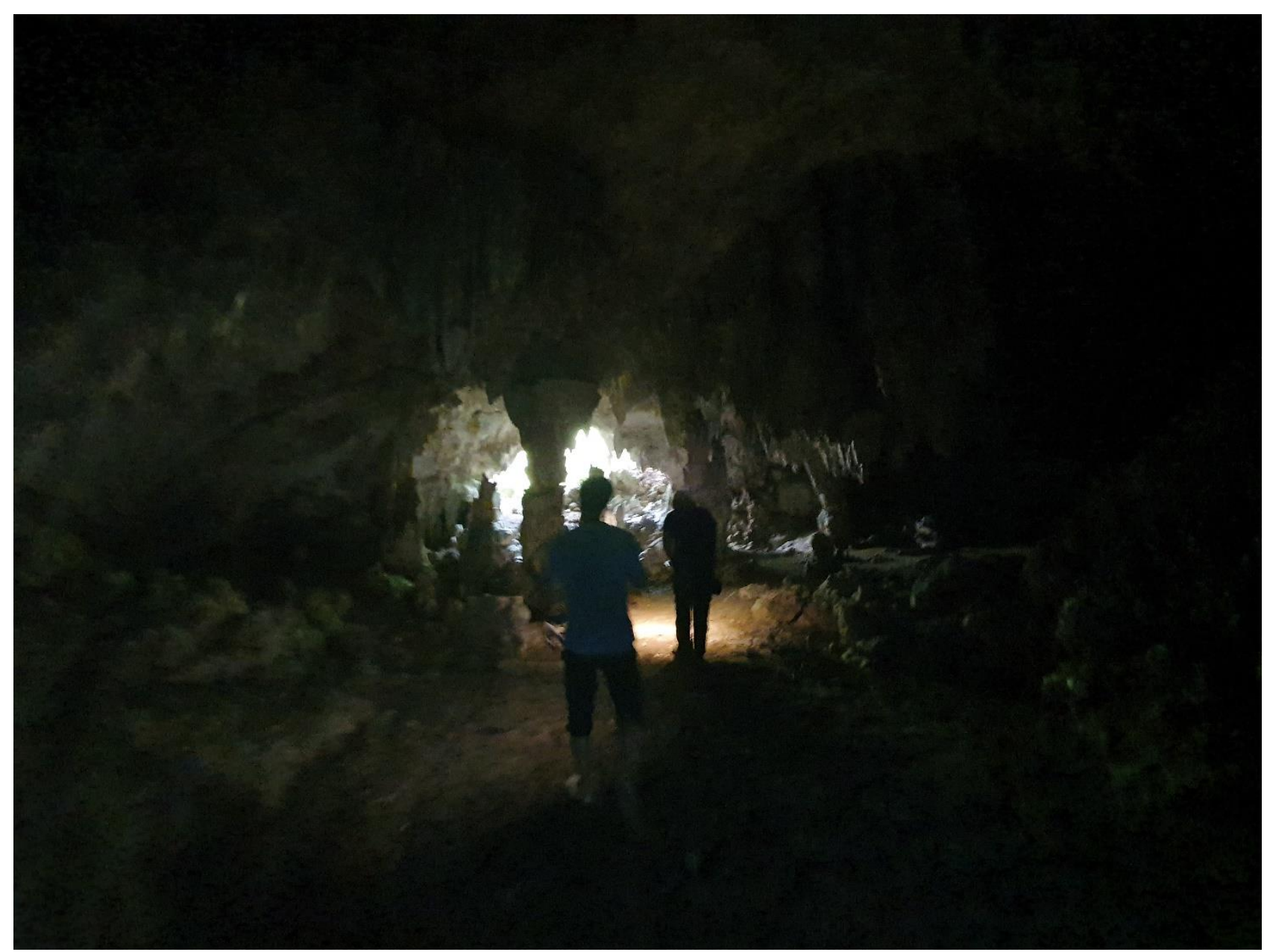

Fig. 43 Inside Rabel Cave. Source: KD Tantuico, 29 February 2020. 


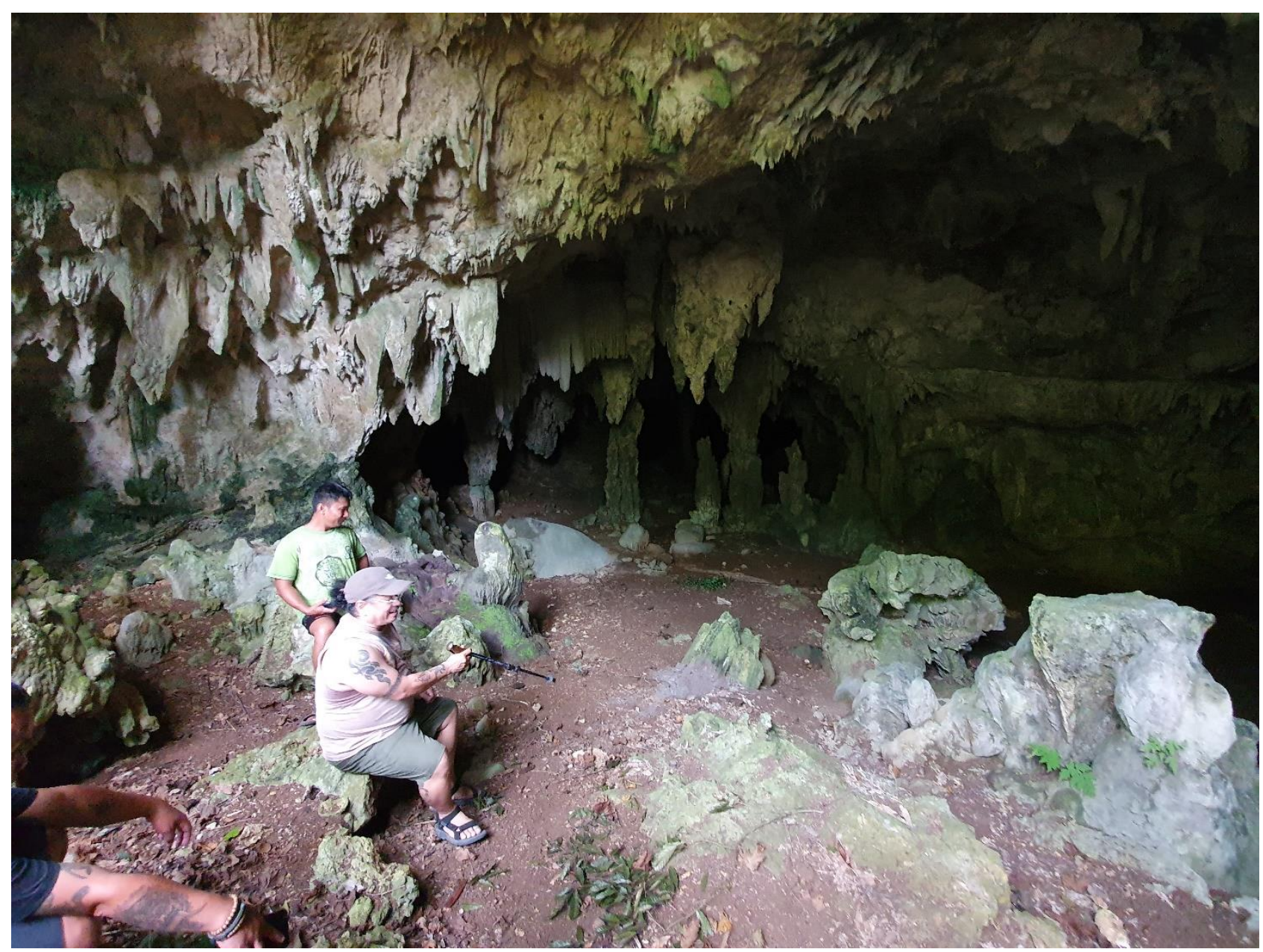

Fig. 44 Dr. Mijares explaining the archaeological history of Rabel Cave. He is the foremost cave archaeologist in the Philippines. Source: KD Tantuico, 29 February 2020. 


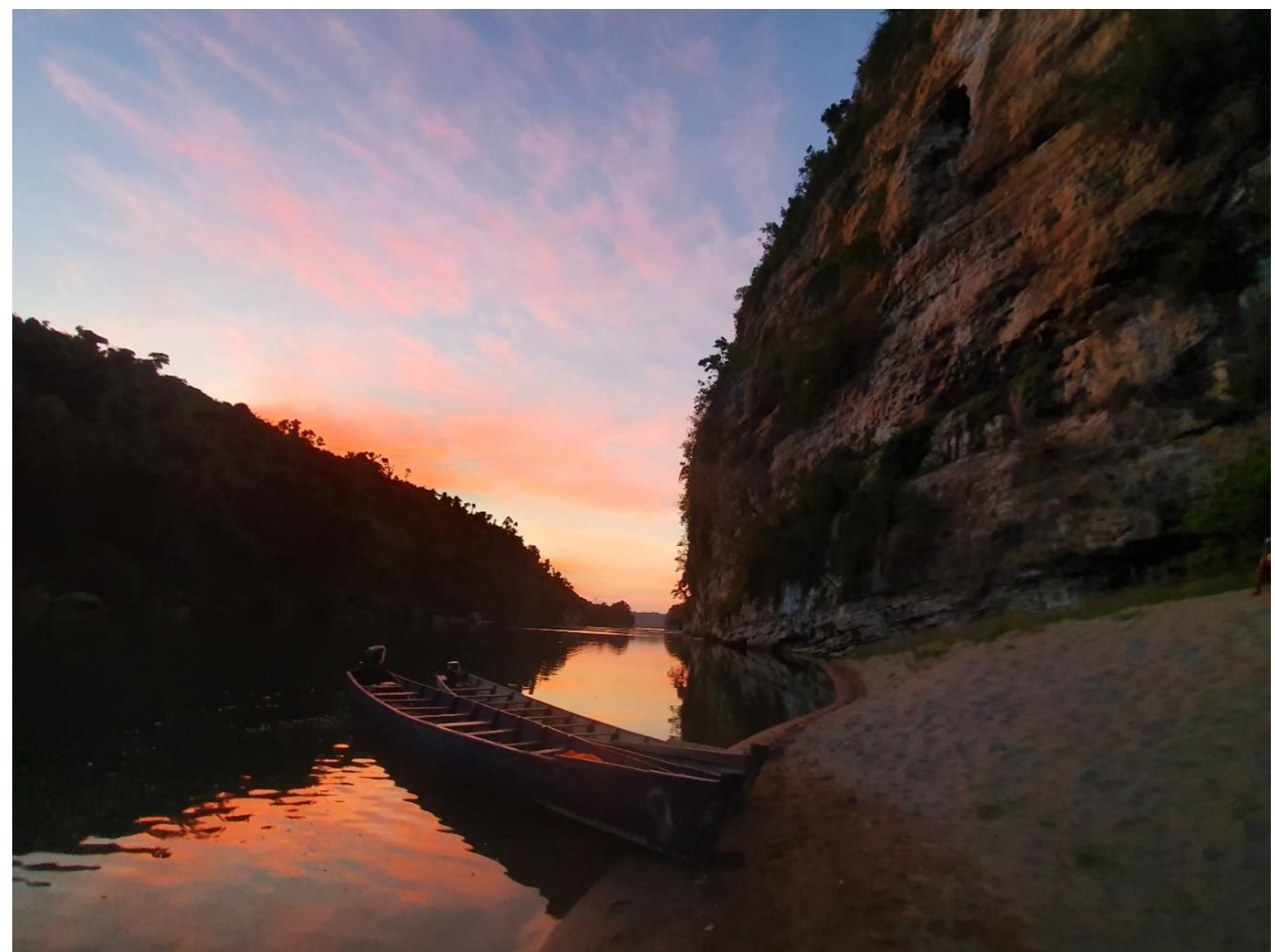

Fig. 45 On another Sunday, our whole group rented two commuter boats and sailed further upstream to a lagoon on the bank of Mororan river to swim and watch the sunset. On the upper right is another cave, where thousands of bats exit at around 6:30 p.m. every day for their evening hunt. Source: KD Tantuico, 7 March 2020.

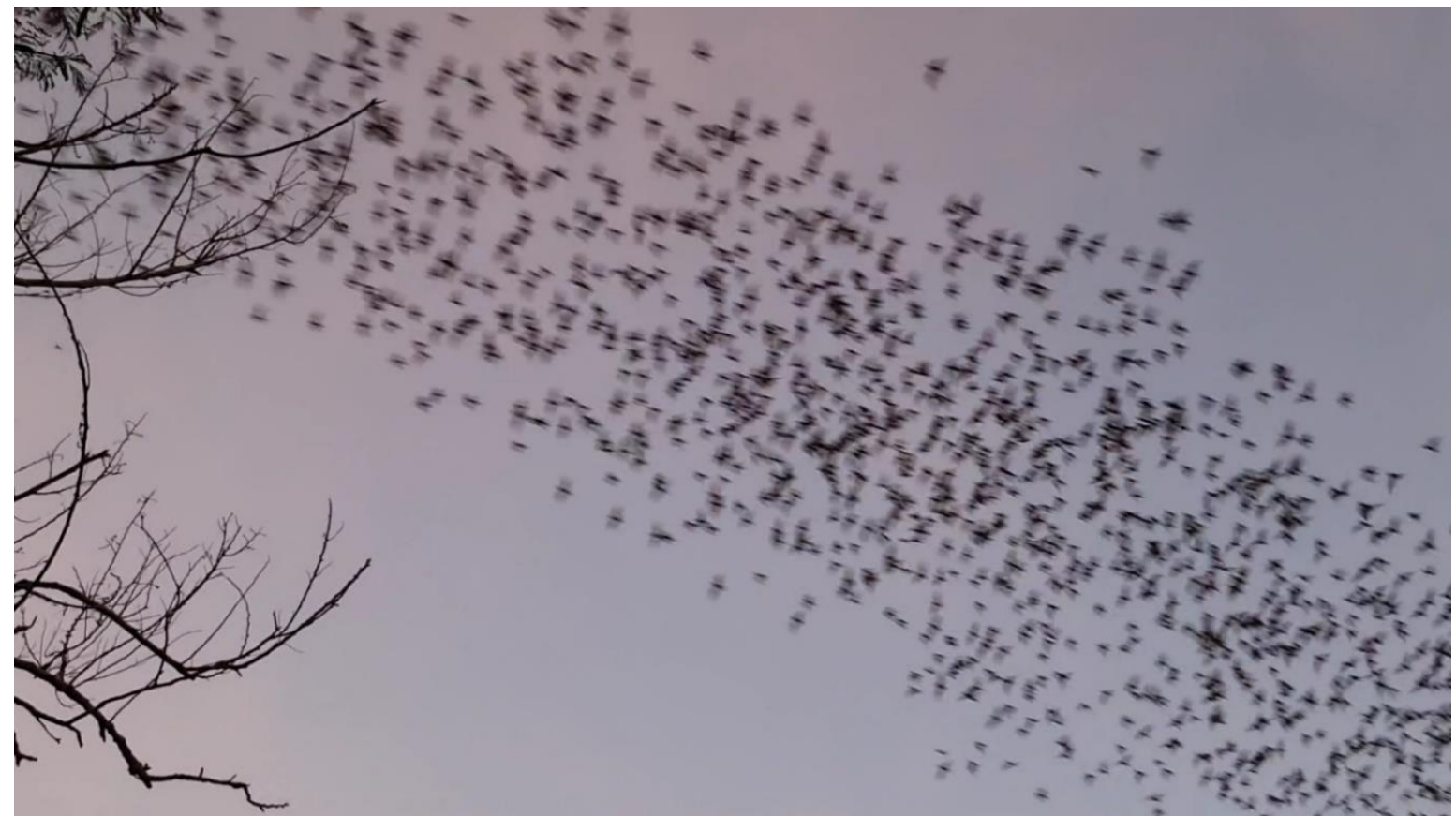

Fig. 46 A screen grab from a video of the thousands of bats that would come from the Mororan cave everyday a little after sunset. They are one of Peñablanca's ecotourism attractions. Source: KD Tantuico, 25 February 2020. 


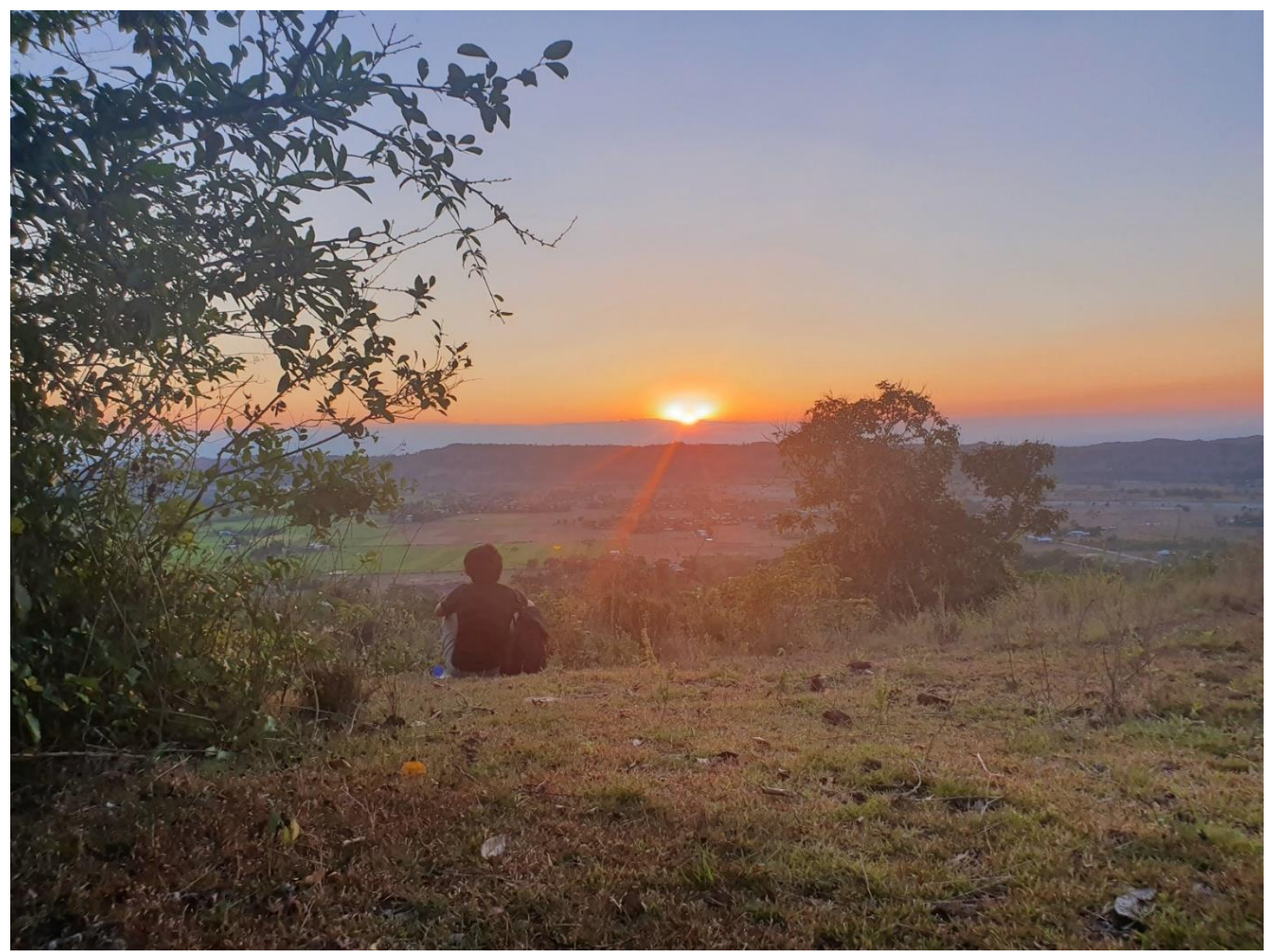

Fig. 47 On our last Saturday in the field, some of us took a short hike in the nearby mountains to watch the sunset. This was also one of the best spots for mobile phone signal, so we could make calls and send text messages to our families and friends. Source: KD Tantuico, 21 March 2020.

\section{Making our way home despite Community Quarantine Protocols}

One factor that made this excavation unique is the fact that almost two weeks before it ended, the whole country had been placed under Enhanced Community Quarantine due to the Novel Corona Virus pandemic. Originally, most of us booked return flights, but all of them were cancelled.

Time came when we had to revise our exit plan and travel back to our homes in Manila. With the assistance of the Chancellor of the University of the Philippines, we were able to obtain an exemption from the travel ban as returning researchers. 


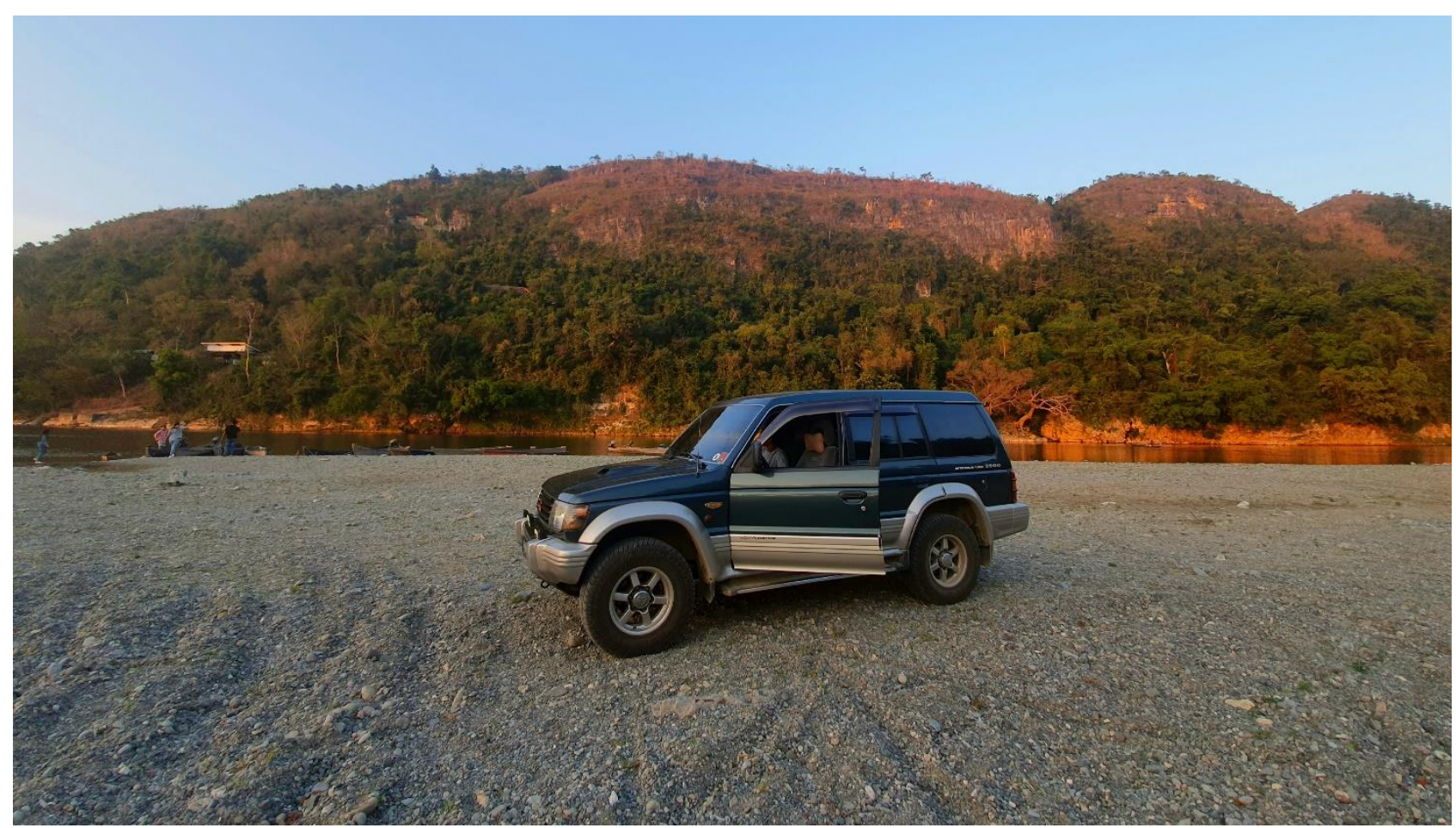

Fig. 48 Our only option was to travel back to Manila in two private cars. With three qulilfied drivers (including me), we test drove our vehicles a few days before departure. Source: KD Tantuico, 18 March 2020. 


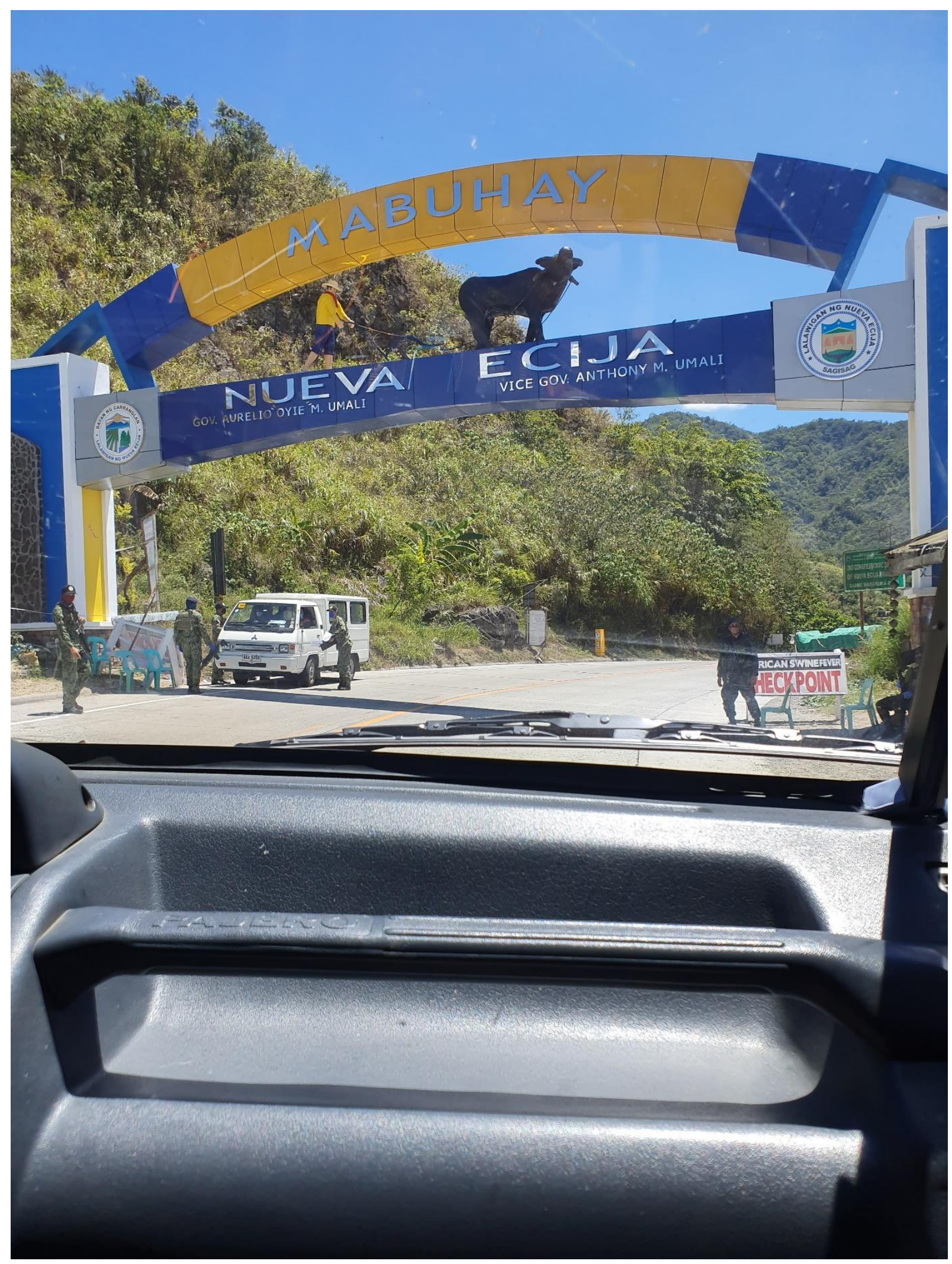

Fig. 49 The drive home took roughly 12 hours to drive 500 kilometers. It was not a leisurely road trip, with the many checkpoints that asked for our papers and checked our temperatures every so often. This is a photo of a checkpoint as we entered the Province of Nueva Ecija, which was about halfway from our point of origin and destination. Source: KD Tantuico, 22 March 2020. 


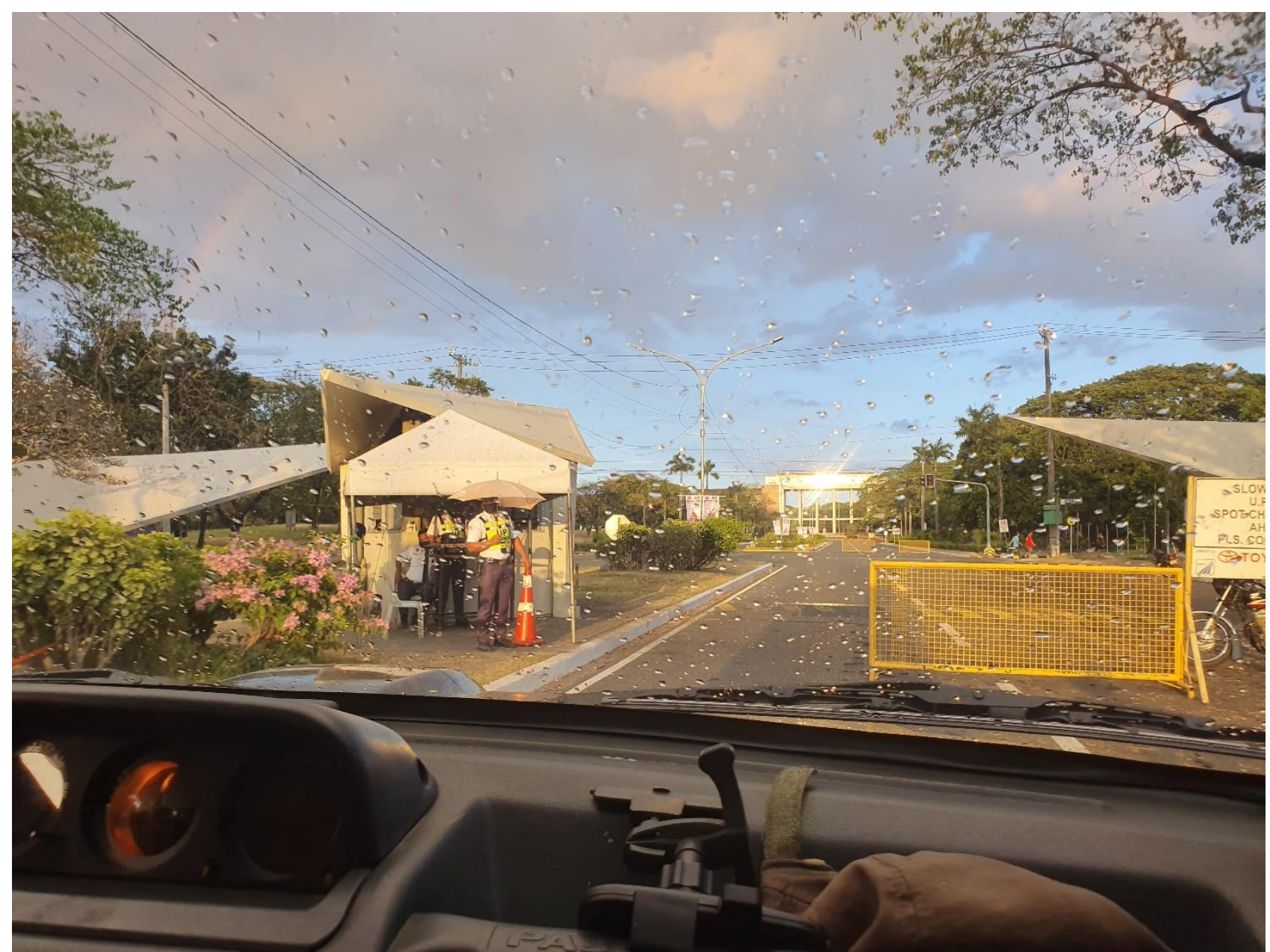

Fig. 50 The last checkpoint was most comforting. It was the checkpoint at the University of the Philippines in Quezon City, Metro Manila. After 12 hours and 500 kilometers, we were home. Source: KD Tantuico, 22 March 2020.

Archaeological excavations are a mix of physical and intellectual activities. Many are not aware of the hard work needed to obtain the archaeological materials currently on display in museums.

Nonetheless, it is one of the most fulfilling experiences one can ever encounter.

This 6-week re-excavation of Callao Cave was certainly a great avenue to apply field methods in archaeology. The laid-back ambiance and the bucolic scenery made the physical demands more bearable. None of us had problems waking up before sunrise every day because we were all eager to work. Despite the challenges encountered every day, up until the long trip back home, we were all relieved that the artefacts transported were intact.

The scientific analysis of the materials obtained during this excavation are undergoing analysis. Hopefully, by the time this article is published, more knowledge on the archaeological heritage of Callao Cave will have been disseminated. 


\section{Acknowledgements}

The 2020 Callao Cave Excavation team would like to acknowledge the following for their invaluable contribution to this project:

- The National Geographic Foundation for the Science and Exploration Grant, with Grant No. GS-KOR-63188R: The Search for Homo luzonensis continues; The 2020 Archaeological Excavations at Callao Cave, Northern Luzon, Philippines;

- Dr. Fidel Nemenzo, Chancellor of the University of the Philippines- Diliman; Dr. Giovanni Tapang and Jelaine Gan of the University of the Philippines- College of Science;

- Governor Manuel Mamba, Atty. Charo Mamba-Villaflor, Mr. Arnold Alonzo, and the Provincial Government of Cagayan;

- Teddy Babaran and the Peñablanca Protected Landscape and Seascape Protected Areas Management Board-Department of Natural Resources;

- Lorie Decena and the Cagayan Provincial Museum and Historical Research Center;

- Jerald Taguinod and the rest of the Callao Cave Tour Guides;

- Jenifer Junio and the Cagayan Tourism Office;

- Kevin Baclig and the Cagayan Heritage Conservation Society

- Cherie Alfiler

The author would like to acknowledge the guidance of Dr. Armand Salvador Mijares and Dr. Grace Barretto-Tesoro. 


\section{The 2020 Excavation Team: Callao Cave Archaeological Project}

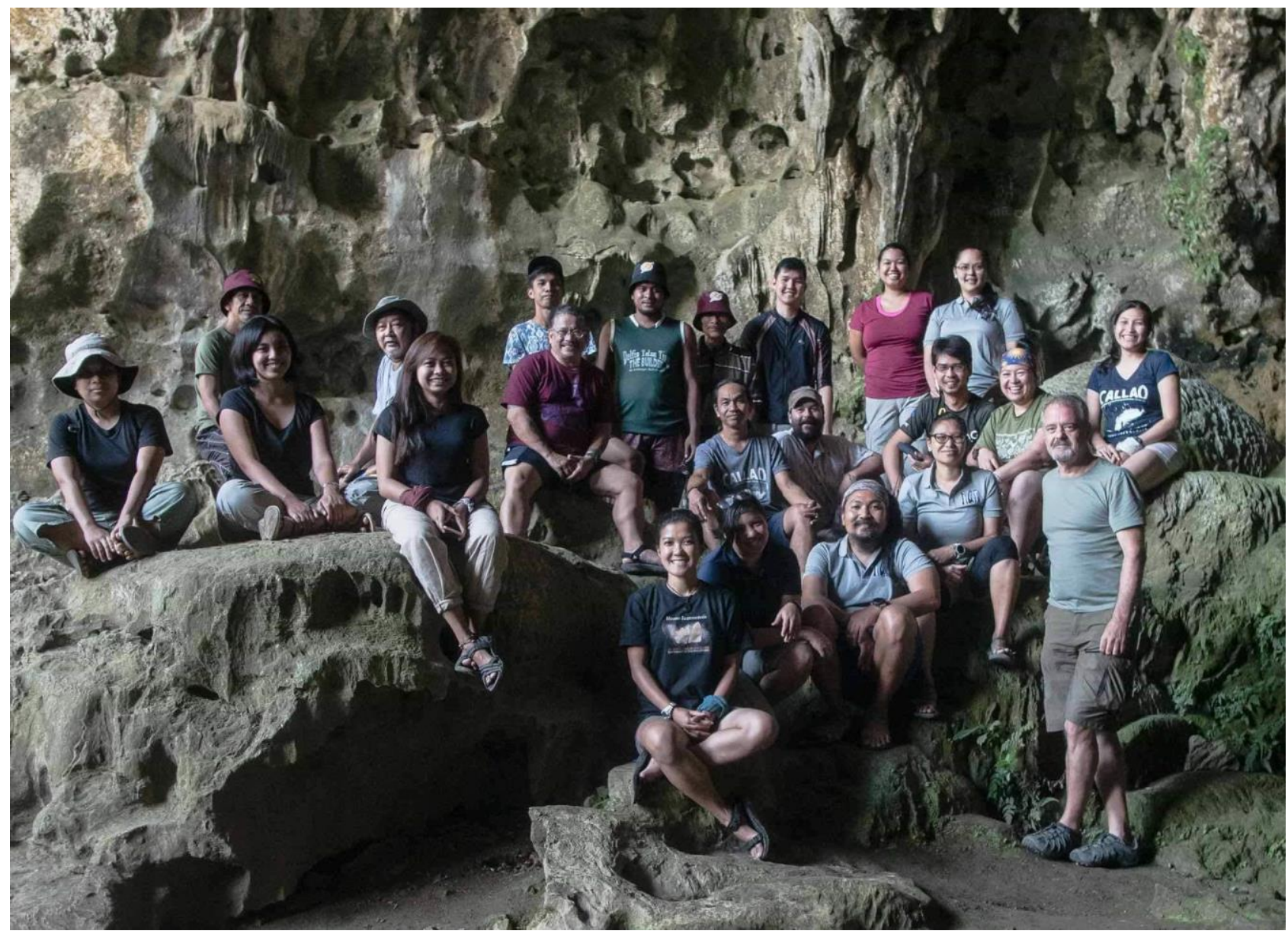

Fig. 51 Callao Cave Archaeological Project 2020 Team. Source: Rob Rownd

- Lead Archaeologist: Dr. Armand Salvador Mijares, Professor, University of the PhilippinesArchaeological Studies Program

- Deputy Field Archaeologist: Kristine Kate Lim, Ph.D. Candidate, Freie Universitat, Berlin ; Visiting Researcher, University of the Philippines-Archaeological Studies Program

\section{Members}

- Charmaine Grace Alvinez, M.A. Candidate, University of the Philippines-Archaeological Studies Program

- Fairuz Bangahan, M.A. Candidate, University of the Philippines-Archaeological Studies Program

- Patricia Cabrera, M.A. Candidate, University of the Philippines- Archaeological Studies Program

- Andrea Dominique Cosalan, M.A., Faculty, University of the Philippines-Archaeological Studies Program

- Jerome Cruz, Field Researcher, Center for Bulacan Studies

- Dr. Eusebio Dizon, Faculty, University of the Philippines-Archaeological Studies Program

- Dr. Florent Détroit, Faculty, Musée de l'Homme

- Alpha Rae Espigar, M.S. Candidate, University of the Philippines-Archaeological Studies Program 
- Maria Rebecca Ferreras, M.A. Candidate, University of the Philippines-Archaeological Studies Program

- Mark Garcia, M.A. Candidate, University of the Philippines-Archaeological Studies Program

- Edilberto Larin, Jr., MA-Fil; M.A. Candidate, University of the Philippines-Archaeological Studies Program

- Eleanor Marie Lim, M.S., University Research Associate, University of the PhilippinesArchaeological Studies Program

- Dante Manipon, M.A., Faculty, University of the Philippines-Archaeological Studies Program

- Arcadio Pagulayan, Building Administrator/Laboratory Technician, University of the Philippines-Archaeological Studies Program

- Trishia Palconit, M.S. Candidate, University of the Philippines- Archaeological Studies Program

- Emil Charles Robles, Ph.D. Candidate and University Research Associate, University of the Philippines-Archaeological Studies Program

- Dr. Juan Rofes, Faculty, University of the Philippines-Archaeological Studies Program

- Rob Rownd, Ph.D. Candidate, University of the Philippines-Archaeological Studies Program

- Dawn Satumbaga, M.S., Faculty, University of the Philippines-Archaeological Studies Program

- Kathleen Tantuico, J.D.University of the Philippines- College of Law and M.A. Candidate, University of the Philippines-Archaeological Studies Program

- Gretchen Velarde, M.S. Candidate, University of the Philippines- Archaeological Studies Program

\section{Local Technicians}

- Eric Dalumay

- Milmar Lumido

- Salvador Malanos Jr.

- Domingo Pagulayan

- Jesus Pagulayan

- Nida Pagulayan

- Ronald Panaga

- Ricardo Tumanguil

Representatives of the National Museum Cagayan Regional Office

- Kirby Balisi

- Ronald Pagulayan

- Adan Soriano 


\section{References}

Congress of the Philippines (2017) Republic Act No. 11038: An Act Declaring Protected Areas and Providing for their Management, amending for this Purpose Republic Act No. 7586,

Otherwise Known as the "National Integrated Protected Areas System (NIPAS) Act of 1992: and for Other Purposes". Manila: Seventeenth Congress of the Republic of the Philippines.

Congress of the Philippines (2010) Republic Act No. 10066: An Act Providing for the Protection and Conservation of the National Cultural Heritage, Strengthening the National Commission for Culture and the Arts (NCCA) and its Affiliated Cultural Agencies, and for other Purposes. Manila: Fourteenth Congress of the Philippines.

Congress of the Philippines (2000) Republic Act No. 9072: An Act to Manage and Protect Caves and Cave Resources and for Other Purposes. Congress of the Republic of the Philippines. Manila: Eleventh Congress of the Republic of the Philippines.

Congress of the Philippines (1992) Republic Act No. 7586: An Act Providing for the Establishment and Management of National Integrated Protected Areas System, Defining its Scope and Coverage, and for other Purposes. Manila: Eighth Congress of the Republic of the Philippines. Fifth Regular Session. 22 July 1991.

Détroit, F, Mijares, A, Corny, J, Daver, G, Zanolli, C, Dizon, E, Robles, E, Grün, R and Piper, P (2019) A new species of Homo from the Late Pleistocene of the Philippines. Nature, 568: 181-186.

Macapagal-Arroyo, G (2003). Proclamation No. 484. Manila: Malacañang Palace.

Maschner, H and Chippindale, C (2005) Handbook of Archaeological Methods. Lanham: Altamira Press.

Mijares, ASB (2005) The Archaeology of Peñablanca Cave Sites, Northern Luzon, Philippines. Journal of Austronesian Studies, 1(2): 65-93.

Mijares, ASB (2006) The Early Austronesian Migration to Luzon: Perspectives from the Peñablanca Cave Sites. Bulletin of the Indo-Pacific Prehistory Association, 26: 72-78.

National Museum of the Philippines (n.d.) National Museum operations Manual, comp. ED Sebastian. Manila: National Museum of the Philippines.

Peralta, J (1978) Field Manual in Archaeology. Manila: National Museum of the Philippines.

Peralta, J (n. d.) Guidelines for Museums. Manila: National Museum of the Philippines.

Quezon, M (1935) Proclamation Number 827: proclaiming Callao Cave as a National Park. Manila: Malacañang Palace. 
Ramos, F (1994) Proclamation Number 416: Amending Proclamation No. 827, dated 16 July 1935, which Reserved the Callao National Park, By Expanding its Coverage to Include Certain Parcels of Land of the Public Domain Situated within the Municipality of Peñablanca, Province of Cagayan, and Renaming the same as the "Peñablanca Protected Landscape”. Manila: Malacañang Palace.

Schneider, T and Panich, L (2008) Total Station Mapping: Practical Examples from Alta and Baja California. Journal of California and Great Basin Anthropology, 28(2): 166-183.

Royer, A (2014) The advantage of using independent subdivisions during archaeological excavations for the study of small vertebrate remains. Paleo, 25: 277-286. 